\title{
Structural Transformation in South Asia
}

\author{
Raghbendra Jha and Sadia Afrin \\ Australian National University
}

\begin{abstract}
This paper models the evolution and determinants of the shares of agriculture, manufacturing and services to GDP for 4 South Asian countries (Bangladesh, India, Sri Lanka and Pakistan) for 55 years: 1960-2014. Determinants of these shares were classified into three broad categories "country fundamentals", "policy" and "regional and reform dummies". Several models including pooled OLS, GLS, panel and quantile regression are estimated. In general, the estimated models fit the data well. Policy conclusions regarding structural transformation are derived from the viewpoint of increasing the shares of the services and, particularly, the manufacturing sectors to GDP. We find that enhanced availability of electrical power and higher capital investment are central to the enhancement of the share of the manufacturing sector. The relationships of the shares with GDP per capita are fragile and, sometimes, counter-intuitive. It is a matter of concern that the impacts of key policy variables such as secondary school enrolment, FDI inflow and trade openness, are not robust across the models and in, some instances, have the "wrong" sign even when significant. It seems that South Asia has undergone a period of arrested industrial development. There is urgent need for policy intervention if this condition is to be redressed.
\end{abstract}

Keywords: South Asia, Structural Transformation, Pooled OLS, Quantile regression, Panel

JEL Classification Code: C22, C23, O11

All correspondence to:

Prof. Raghbendra Jha,

Arndt-Corden Department of Economics,

College of Asia and the Pacific

H.C. Coombs Building (09)

Australian National University,

Acton, ACT 2601, Australia

Phone: + 6126125 2683; Fax: + 6126125 3700; Email: r.jha@anu.edu.au 


\section{Structural Transformation in South Asia}

\section{Introduction and review of the literature}

There are two school of thoughts in the literature on the links between economic growth and structural composition of output and/or employment. On the one hand the neoclassical school of economic growth would argue that the structure of output hardly matters for economic growth. On the other hand several economists, most famously Simon Kuznets and others, have argued that economic growth has been involved with a change in the composition of gross domestic product (GDP) and/or employment. Indeed this change is essential for sustained economic growth and rising incomes.

There is widespread consensus now that these two schools of thought are not mutually contradictory. In this context Echeveria (1997) builds a dynamic general equilibrium model to show that growth affects sectoral composition of output and vice versa. Thus, there is a mutual cause and effect relation between economic growth and composition of aggregate output.

The empirical evidence on structural transformation of an economy during the process of economic development is quite convincing. Historical data on the most of the developed countries of today show that they went from being primarily agricultural economies to primarily manufacturing and, then, primarily services. At early stages of development when a country is heavily specialized in agriculture, labour productivity is low and the economy is largely stagnant. With increasing labour productivity there is economic growth and higher wages. However, the prospects for rapid productivity growth in agriculture are limited so that labour migrates to the manufacturing sector where there is greater scope for higher productivity and economic growth. This enhanced productivity and wages, in due course of time, lead to a shift of labour to services where there is greater scope for productivity growth. Thus, rising GDP per capita is associated with a decreasing share of agriculture, and increasing share of value added, first in manufacturing, and then services. Similar trend applies to sectoral shares of employment to total employment for these three sectors. Empirical evidence in support of this transition has been well explored in a number of contributions starting with the pioneering work of Simon Kuznets. ${ }^{1}$

\footnotetext{
${ }^{1}$ For a review of this literature and the evidence see Kuznets (1973) and Kuznets (1966).
} 
Other notable contributors to this literature include Hollis Chenery (1960), Arthur Lewis, Syrquin and Baumol.

In more recent times Timmer et al. (2012) take the work of Echeveria (1997) as a point of departure and underscore the fact that structural transformation is both the cause and effect of economic growth. They define structural transformation as a process by which (a) the shares of agriculture in GDP and employment fall over time, (b) there is increased migration as people move from rural to urban areas, (c) an agriculture and rural sector based economy is replaced by an industrial and urban sector based economy, and (d) a demographic transformation whereby high birth and death rates are replaced by low birth and death rates. Any existing dualism between the agricultural and the non-agricultural sectors gradually disappears over time.

This view of structural transformation argues that economic growth is a process that changes the composition of output as well as the pattern and distribution of employment across different sectors of the economy. Traditional agriculture is thought of as the base for less developed countries (LDCs). In such societies land and labour productivity are low and not much surplus is saved for investment. With the improvement of labour productivity, however, some labour is freed up for employment in the manufacturing sector which has higher labour productivity and, hence, higher wages. Higher incomes lead to increased savings and, hence, investment. This then further spurs up economic growth and the accompanying rise in labour productivity facilitates movement of labour from manufacturing to services. A key characteristic of this narrative is that economic growth is viewed as a long-term phenomenon which engineers structural change in the economy and is, in turn, affected by these changes. This is to be differentiated from annual or even quarterly growth figures which are widely reported in media and other outlets. Figure 1 provides a visual representation of the structural transformation visualized by the above arguments.

\section{Figure 1 about here.}

The $\mathrm{x}$-axis in Figure 1 measures time and GDP per capita in the long run. The y-axis indicates sectoral shares in output/employment. Over time as GDP per capita rises the share of agriculture declines and those of services and manufactures rise. After reaching a threshold level of GDP per capita, the share of manufactures starts to plateau out (indicating industrial 
stagnation) and could even decline (indicating de-industrialization). The share of the services sector, however, continues to rise.

Many developed countries have followed this pattern of structural change. Even the Newly Industrialized Countries of Asia (including China) have experienced structural changes along these lines. All these countries raised their per capita incomes manyfold during short periods of time and are now in or close to being post-industrial societies.

However, this pattern of sectoral transformation has not been followed in a number of developing countries. Particularly in South Asia, the relative decline of the share of agriculture in GDP has been accompanied by a huge rise in the share of the services sector whereas the manufacturing sector has more or less stagnated. It would be desirable to alter the sectoral share pattern towards greater share of manufacturing, given unrealised higher productivity in manufacturing and the prospects of higher employment growth in the manufacturing sector compared to both agriculture and services, not to mention the fact that the current state of the South Asian economies represents arrested or incomplete industrialization.

The role of what may be called fundamentals of the economy (such as GDP, population, land etc.) and policy measures (such as trade openness) in facilitating this structural transformation can be best understood in a formal model of the determinants of the shares of the value added of various sectors in total value added. Taking a cue from Dabla-Norris et al. (2013) the present paper examines the determinants of the sectoral share of value added in four countries of South Asia (Bangladesh, India, Sri Lanka and Pakistan). The sectors considered are agriculture, manufacturing and services. the determinants of structural transformation are analysed based on sectoral value added to total GDP only. We introduce a number of additional policy variables on the right hand side of the regression equations in order to better understand possible policy levers that affect transitions in sectoral shares in the continent as well as country dummies. The use of quantile regression helps us understand how structural transformation is occurring at various levels of sectoral contributions to GDP and which variables are important at these levels in these 
countries. ${ }^{2}$ Kochhar et al. (2002) conduct an analysis for structural transformation in the various states of India.

The plan of this paper is as follows. Section II discusses data and methodology whereas section III presents all the results. Section IV concludes.

\section{Data and Methodology}

Table 1 provides descriptive statistics for the variables used in the analysis. The data are from World Development Indicators of the World Bank.

\section{Table 1 about here.}

Notation for the variables used in the analysis is as follows.

The variables used in the analysis are: $c i d=$ country code ( 1 for Bangladesh, 2 for India, 3 for Sri Lanka and 4 for Pakistan); Time (year); agri = share of agriculture in total value added; manuf $=$ share of manufacturing in total value added; service $=$ share of services in total value added; lland $=\log$ of land area in square kilometers; lpop = log of total population; arable = arable land as percentage of total land; $a g e=$ age dependency ratio, overall; $\lg d p=\log$ of GDP per capita (GDP is measured in constant 2005 USD); $l g d p s q=$ square (log of GDP per capita); edus = secondary enrolment ratio; lpower $=\log$ of electricity consumption per capita in Kwh; $f d i=$ FDI inflows as percentage of GDP; trade = trade as percentage of GDP; capital = gross capital formation as percentage of GDP; dum 92 = dummy for the period 1992 (assuming reforms started in 1992).

These variables are grouped into three different categories: (a) Fundamentals (lland, lpop, arable, age, lgdp and lgdps); (b) Policy variables (educs, lpower, trade, fdi and capital); and (c) A reform period dummy (dum92) and country dummies for the chosen countries of South Asia. We use data from 1960 to 2014 which yields 55 data points giving a potential total of $220(55 * 4)$ observations for each variable. However, for Bangladesh

\footnotetext{
${ }^{2}$ We would have liked to conduct this analysis with shares in employment as well. But the data on this variable was too scant to conduct regression modelling.
} 
the series begin in 1971 giving us 44 data points (176 observations for each variable) for that country. Hence, we have an unbalanced panel.

Panel variation in the variables is described in Table 1.

\section{Table 1 about here.}

"Overall", "between" and "within" variations for each variable are depicted in Table 1. In this Table $N$ refers to the total number of observations across countries and across time, $n$ refers to the number of countries for which observations are available and $\mathrm{T}$ refers to time period for which the data are available. Clearly, $\mathrm{N}=\mathrm{n}^{*} \mathrm{~T}$. For those variables for which data is not available for all time periods and/or all counties $\mathrm{N}=\mathrm{n} * \mathrm{~T}$-bar where $\mathrm{T}$-bar again refers to the time period for which data are available. Table 1 summarizes the data gaps in the variables. Thus, for the variable "agri" a total of 209 data points are available for the four countries.

Table 2 depicts basic statistics for each of the four countries: Bangladesh, India, Sri Lanka and Pakistan.

\section{Table 2 about here.}

In this paper we estimate several different versions of the model in order to check for the robustness of the results and establish the role of policy variables.

The panel data representation of the model to be estimated in its general form is,

$$
y_{i t}=x_{i t}^{\prime} \beta+z_{i}^{\prime} \alpha+\varepsilon_{i t}=x_{i t}^{\prime} \beta+c_{i}+\varepsilon_{i t}
$$

$$
\mathbf{y}_{\mathrm{it}}=\mathbf{x}_{\mathrm{it}}{ }^{\prime} \boldsymbol{\beta}+\mathbf{z}_{\mathrm{i}}^{\prime} \boldsymbol{\alpha}+\boldsymbol{\varepsilon}_{\mathrm{it}}=\mathbf{x}_{\mathrm{it}}{ }^{\prime} \boldsymbol{\beta}+\mathbf{c}_{\mathrm{i}}+\boldsymbol{\varepsilon}_{\mathrm{it}}
$$

where $y_{i t}$ is share of value added of sector $i$ ( $\mathrm{i}=$ agriculture, manufacturing, services) in total value added. There are $k$ regressors in $\mathrm{x}_{\mathrm{it}}$ but this does not include a constant term (Greene, 2008). $\mathrm{Z}_{\mathrm{it}}$ consists of a constant term and other individual (i) specific variables.

If all the $\mathrm{Zi}$ are observable then (1) becomes a standard regression model. In this case we are justified in running a pooled OLS regression. This will be the case if

$$
\mathrm{E}\left(x_{i t}^{\prime} \varepsilon_{i t}\right)=E\left(x_{i t}^{\prime} c_{i}\right)=0 \text { for } t=1,2, \ldots \ldots T
$$




\section{$E_{\left(x_{i t}{ }^{\prime} \varepsilon_{i t}\right)}=E_{\left(x_{i t}{ }^{\prime} c_{i}\right)=0 \text { for } t=1,2, \ldots T}$}

According to Greene (2008) this yields consistent estimates.

However, this assumption is difficult to satisfy for many samples. Several reasons for this can be cited. Thus, McManus (2011) suggests that this may be because of (i) hierarchical data sampling methods, (ii) multistage probability samples that incorporate cluster based sampling designs which have errors that are correlated within clusters, (iii) time series data can exhibit serial correlation and (iv) panel data can be correlated within the unit of observation, in this case countries.

Hence, the pooled OLS estimates may not be efficient. Efficiency can be improved by combining pooled OLS with cluster-consistent standard errors. We pursue this route in this paper. Further, we also estimate pooled OLS assuming cross-equation error term correlation which necessitates the use of Generalized Least Squares (GLS) methods. We further estimate fixed effects and random effects models and use the Hausman test to choose the right estimation technique.

Furthermore, given the vast spatial differences within South Asia as evident from Table 2 we use quantile methods on the pooled model to distinguish threshold effects. The OLS estimator minimizes the sum of squared residuals and, thus, gives large weightage to large deviations from the mean. If the sample size is small then the results can be very sensitive to a small number of outlier observations. To tackle this minimizing absolute deviations from the mean has been suggested and is referred to in the literature as Least Absolute Deviation (LAD). The idea is to minimize the absolute deviations from the median. This is a special case of the quantile regression

$$
\operatorname{Prob}\left[y_{i t} \leq x_{i t}^{\prime} \beta\right]=q .
$$

where $q=50 \%$ in the case of LAD.

The method of qreg2 (available in the STATA program) was followed in this paper (Machado et al., 2011). Quantiles are differentiated by shares of different sector in GDP. We ran each equation one at a time for the different quantiles and did not run all the regressions simultaneously. In contrast to qreg, qreg2 produces standard errors and t-statistics that are asymptotically valid under heteroskedasticity and intra-cluster correlation. Machado et. al. 
(2011) test for intra-cluster correlation and show that qreg can produce robust standard errors but not clustered-robust standard errors. Qreg2 can produce this.

To check for the validity of the quantile regressions, we can compare the estimated coefficients at different quantiles with the pooled OLS coefficients If we want to justify the use of quantile regression, then the difference between the estimated coefficients at mean, which is the OLS estimates and the estimated coefficients at various quantiles, should be statistically significant. If the quantile coefficient is outside the OLS 95 per cent confidence interval, then we have significant differences between the quantile and the OLS coefficients. If the coefficients for the quantile regression lie within the 95 per cent confidence intervals around the respective OLS estimates then there is not much advantage of opting for the quantile regression.

A similar way to examine is to graph the results. The coefficients for every regressor is plotted against the respective quantiles. This graph also has the OLS estimate along with the 95 per cent confidence interval associated with this OLS estimate which are horizontal lines as they are fixed across quantiles. If quantile coefficients remain within these 95 per cent confidence intervals band then no significant traction is obtained from the quantile regression and the OLS results are adequate.

Finally, some recent literature suggest quantile regression on panel data but this issue is far from settled and there is not consensus on the relative performance of those estimators. However, there is consensus on the efficacy of the qreg2 method. Hence, we adopt this method along with clustered standard errors for pooled data.

\section{Results and Discussion}

Figure 2 provides scatter plots of sectoral value added (in percent in y-axis) against log of GDP per capita (x-axis) for South Asia and each of the four countries for all years.

\section{Figure 2 here.}

For South Asia and each of the countries the share of agriculture value added to total GDP falls steadily with the growth of GDP per capita. The share of manufacturing rises and then reaches a plateau of about 20 per cent in the case of South Asia. A similar pattern is observed for India 
and Bangladesh but not for Pakistan and Sri Lanka. The share of services rises with per capita GDP growth in South Asia as a whole and in each constituent country.

Thus, evidence for a Kuznets-type structural transformation, even in the raw data, in South Asia is weak. This pattern is being followed for the agricultural and services sectors but not for manufacturing. The latter is particularly true for Pakistan and Sri Lanka. The South Asian regional transformation patterns for agriculture and services sectors are same as those in developing Asia and advanced economies groups (see Dabla-Norris et al. 2013 for more) during same period. However, manufacturing share for advanced economies appear with a gradual declining trend while that of developing Asia is in rising trend, similar to South Asia. An important issue to address here is whether the patterns observed in Figure 2 persist when control variables in the form of country fundamentals, policy variables and country dummies are introduced. We now investigate this.

\section{Pooled OLS Regression Results}

In all the regression results we differentiate between fundamental determinants of sectoral shares (e.g. land area, GDP etc.) and policy determinants of these shares (e.g. enrolment in secondary education, FDI, trade openness, etc.). Table 3 reports results on pooled OLS regression for South Asia with regional and time dummies for the case where only fundamental determinants of sectoral shares are considered.

\section{Table 3 about here.}

The share of agriculture rises significantly with land, arable land and age and falls with population. The country dummies and time dummy are insignificant. The share of manufacture rises with population and falls with age and arable land. Other variables are insignificant. The share of the service sector rises with population and falls with land and arable. It has a U shaped relation with GDP, i.e., the share of services in aggregate value added falls and then rises. An important conclusion from this table is, rises in population has led to shift in labor to the manufacturing and services sectors and only the services sector has any significant relation with GDP. 
We also estimated the pooled OLS model with clustered standard errors. The results are reported in Table 4. However, since we do not get meaningful F-statistics for any of the regressions we do not discuss the results here. ${ }^{3}$

Table 4 here.

In Table 5 we report on pooled OLS estimation for the extended model with policy variables. Among the "fundamentals" the share of agriculture rises with land. Among the policy variables the share of agriculture falls with power and capital and rises with trade. No other variable is significant. Among the fundamentals the share of manufacturing falls with land and arable. There is a U-shaped relation with GDP per capita. Among the policy variables the share of manufactures falls with FDI and rises with capital. The coefficient of dum92 is positive but insignificant. The dummy for India is positive and significant and that for Sri Lanka is negative and significant. None of the fundamentals significantly affect the share of the services sector. Among the policy variables the share of the services sector falls with trade openess and rises with capital.

Table 5 here.

Table 6 reports results on Zellner's Seemingly Unrelated Regression (SUR) with some cross equation restrictions (since these were not rejected by the unrestricted SUR regression). The SUR model is constructed with the fundamentals and the policy variables. None of the fundamentals is a significant determinant of the share of agriculture in this model. Share of agriculture rises with trade but falls with power and capital. Dum92 is positive and significant. Although GDP has positive sign it is insignificant. Policy variables are important. The share of manufactures falls with land and pop and rises with age. It has a U-shaped relation with GDP per capita - share of manufactures first falls and then rises as GDP per capita rises. The share of manufactures rises with power. The coefficient of dum92 is positive and insignificant. The coefficient of the dummy for India is positive and significant and negative and significant for Sri Lanka. In the case of services both country fundamentals and policy variables are important. The share of the services sector has an inverted U-relation with GDP. This share

\footnotetext{
${ }^{3}$ STATA does not report the F stat because, number of cluster is not sufficient. If number of regressors is greater than the number of clusters, then the cluster-robust variance-covariance matrix is not full rank. This is why F test fails. Because, we have only 4 countries, hence 4 clusters, the F test fails here.
} 
rises with power, FDI and capital falls with trade. The coefficient of dum92 is positive and significant. The country dummies are insignificant.

Table 6 here.

In Table 7 we report results on panel fixed effects regression for the model with country fundamentals only. In this model the share of agriculture rises with arable land and age dependency and falls with population. There is no significant relation with GDP. The share of manufacturing rises with population and falls with arable land and age dependancy. The share of services rises with pop and falls with arable. This share has a U-shaped relation with GDP. Dum92 is positive and significant.

Table 7 here.

For the sake of completeness results for the random effects model are shown in Table 8 but are not discussed since the fixed effects model is preferred.

Table 8 here.

Panel regressions with policy variables are shown in Tables 9 and 10. The results do not favor fixed or random effects uniformly and are, therefore, not discussed further.

Tables 9 and 10 here.

\section{Quantile Regression Results}

In Figure 3 we plot the dependent variable (sectoral shares) across the quantiles and the fractions of the data that are associated with each quantile considered. Particularly noticeable about this diagram is the fact that a very large part of the manufacturing sector data hover around the $12^{\text {th }}$ to $15^{\text {th }}$ quantiles indicating stagnant share of manufacturing in South Asia.

\section{Figure 3 here.}

Regression results for quantile regressions for $0.1,0.25,0.5,0.75$ and 0.9 quantiles using only the country fundamentals alone for the agricultural sector are presented in Table 11. For the manufacturing sector these are presented in Table 12 and for the services sector in Table 13. 
Tables 14, 15 and 16 present the corresponding results for agriculture, manufacturing and services when policy variables are included in the analysis.

\section{Tables 11 to 16 here.}

Table 11 indicates that no variable is significant in the 0.1 and 0.25 quantiles regressions for the agricultural sector. For the median and 0.75 quantile regressions only arable land has a positive and significant effect on the share of agriculture. However, for the 0.9 quantile the share of agriculture has a significant U-shaped relation with GDP. Thus, at primary stages of development when agriculture has high share to GDP (such as in 0.9 qunatile) then country fundamentals play an important role in the structural transformation.

Table 12 indicates that for the $0.1,0.25$ and 0.5 quantiles of the manufacturing sector shares only arable land has a significant (and negative) impact. All other coefficients are insignificant except for dum92 which is negative and significant for the 0.5 and 0.9 quantiles. For the 0.75 and 0.9 quantile regressions no variable is significant.

Table 13 indicates results for the share of the services sector. In the 0.1 quantile regression land and arable have negative and significant coefficients whereas dum92 has a positive and significant coefficient. Thus, the structural reform policy adopted by most of the countries in the region during the 1990s was successful in boosting service sector growth. No variable is significant in the 0.25 quantile regression. In the median regression pop has a positive and significant coefficient and land has a negative and significant coefficient. In the 0.75 quantile regression both land and arable have negative and significant coefficients. All other coefficients are insignificant. In the 0.9 quantile regression pop and dum 92 have positive and significant coefficients whereas land and arable have negative and significant coefficients.

These quantile regression results change substantially when policy variables are introduced. In particular, several more variables become significant. Table 14 indicates that for the 0.1 quantile for agriculture, among the fundamentals pop and arable are positive and significant whereas land and age are negative and significant. The share of agriculture has a significant $U$-shaped relation with GDP for this quantile. Among the policy variables trade has a positive and significant impact whereas power, FDI and capital have negative and significant impacts. Dum92 has a 
negative and significant coefficient whereas the dummy variables for Sri Lanka and Pakistan are positive and significant. For the 0.25 quantile regression among the fundamentals pop and arable have positive and significant impacts. Age has a negative impact and there is a significant Ushaped relation with GDP. Secondary education, FDI and trade openness have positive and significant impacts whereas capital has a negative impact. Dum92 has a negative and significant impact whereas the dummies for Sri Lanka and Pakistan are each positive and significant. For the median regression among the fundamentals only land has a significant (and positive) impact. For the 0.75 quantile among the fundamentals only arable has a significant (and negative) impact. Among the policy variables power and capital have significant (and negative) impacts. For the 0.9 quantile among the fundamentals only land has a significant (and positive) impact. Among the policy variables edus, has a positive impact and power and capital each have negative and significant impacts.

Table 15 reports on the quantile regression results for the manufacturing sector when policy variables are also considered. Broadly speaking, except land area most of the country fundamentals have significant impacts for manufacturing sector transition from low to high quantiles. Among policy variables, electric power consumption has positive and significant impacts across quantiles whereas FDI has negative and trade policy has positive and significant impacts in upper quantiles only. For the 0.1 quantile among the fundamentals age has a positive and significant impact whereas pop and arable have negative and significant impacts. There is a significant U-shaped relation with GDP across the quantiles. The dummies for Sri Lanka and Pakistan have negative and significant coefficients. In the 0.25 quantile regression among the fundamentals age has a positive and significant impact and arable has a negative and significant impact. Among the policy variables, power has a positive and significant coefficient. Dummies for Pakistan and Sri Lanka are negative and significant. In the median regression, . among the policy variables power has a positive and significant coefficient and FDI has a negative and significant coefficient. Dummies for Sri Lanka and Pakistan are negative and significant. For the 0.75 quantile regression among the fundamentals age has a positive and significant impact whereas pop and arable have negative and significant impacts. Among the policy variables power has a significant and positive impact whereas FDI has a negative impact. Dum92 has a positive and significant coefficient whereas the dummies for Sri Lanka and Pakistan are negative 
and significant. For the 0.9 quantile regression among the fundamentals age has a positive and significant impact whereas pop and arable have negative and significant impacts. Among the policy variables power and trade have significant positive impacts whereas FDI has a negative impact. The coefficient on Dum92 is positive and significant whereas the dummies for Sri Lanka and Pakistan are negative and significant.

Finally, Table 16 reports on the quantile regressions for the services sector when policy variables are included. For the 0.1 quantile among the fundamentals arable has a positive and significant coefficient whereas land and age have negative and significant coefficients. Among the policy variables edus and power have positive and significant impacts. The dummy variables for Sri Lanka and Pakistan have positive and significant coefficients. For the 0.25 quantile among the fundamentals arable has a significant and positive coefficient whereas land has a negative and significant coefficient. Among the policy variables edus has a positive and significant coefficient. Dummy variables for Sri Lanka and Pakistan are significant and positive. In the median regression no variable has a significant coefficient. In the regression for the 0.75 quantile among the fundamentals land has a negative coefficient and there is an inverted-U relation with per capita GDP. The impact of GDP on services is significant only in the upper quantiles $\left(75^{\text {th }}\right.$ and $90^{\text {th }}$ ). Among the policy variables trade has a negative and significant coefficient and capital has a positive and significant coefficient. The coefficient on dum92 is positive and significant. In the 0.9 quantile regression for the fundamentals coefficients on arable and age have positive signs and there is a significant inverse U-shaped relation with GDP. Among the policy variables FDI and capital have significant positive impacts whereas trade has a negative impact. The coefficient on dum92 is positive and significant whereas the dummies for Sri Lanka and Pakistan are negative and significant.

Summary results for the Tables are reported in Tables 17A (for the share of agriculture); $17 \mathrm{~B}$ (for the manufacturing sector) and $17 \mathrm{C}$ (for the services sector). Comparison of regression output across different estimation techniques points towards the robustness (or otherwise) of the results. In many cases quantile regressions give substantial traction. Hence, we report estimates on them.

Tables 17 A, B, C here. 
Table 17 A indicates that among the fundamental determinants land and arable tend to increase the share of agricultural value added in the pooled OLS model. Other estimation techniques including the quantile methods give somewhat ambiguous results. The impact of lpop is negative and significant only in the pooled OLS and Panel Fixed effects model and positive and significant for the lower quantiles $(0.1$ and 0.25$)$ in the quantile regression. The larger the age dependency the greater the share of agriculture in value added in most regressions except for the 0.1 and 0.25 quantiles in the quantile regression case. The respective signs of lgdp and lgdpsq, where significant indicate a U-shaped relation between the share of agriculture in value added and GDP per capita.

Among the policy variables greater availability of electrical power is associated with lower share of agriculture in value added. The effect of secondary school enrolment is largely insignificant. Greater trade openness is associated with higher share of agriculture whereas FDI has an insignificant effect except in the quantile regression for the 0.25 quantile where it has a positive impact. Higher capital investment is associated with a lower share of agriculture in value added. The dummy variable for the reforms beginning 1992 has a positive and significant effect in the SUR model. It has a negative and significant sign in the random effects panel model (which is not preferred) and is negative and significant for the quantile regression for the $0.1,0.25$ and 0.25 quantiles only. The dummy variable for India is insignificant whereas the dummy for Sri Lanka has a positive and significant sign for the pooled OLS model and quantiles lower than the median for Sri Lanka. The dummy for Pakistan is largely insignificant except for the lower quantiles in the quantile regression.

For the manufacturing sector lland has a negative and significant coefficient in most regressions as does arable. Higher supply of land and arable land lower the share of manufacturing in value added. Lpop Population has a positive sign in the pooled OLS and panel fixed effects models whereas it has a negative and significant sign in the SUR model and for some quantiles in the quantile regression. Except for the panel fixed effects model age dependency has a positive and significant impact on the share of manufacturing including in all quantiles in the quantile regression. Except for pooled OLS and the panel fixed effects models per capita GDP and share of manufacturing have a U-shaped relation in all models including the quantile effects models. Among the policy variables edus has an insignificant impact whereas the availability of electrical 
power has a significant and positive impact. By and large FDI has a negative and significant impact indicating that not much FDI is going into the manufacturing sector. Wherever significant the impact of capital investment is positive and significant. The reform dummy dum92 is positive and significant indicating that the reforms have had a positive impact on the share of manufacturing. The India dummy is positive and significant in two equations whereas the dummy for Sri Lanka is negative and significant for two equations.

The summary results for the services sector in Table $17 \mathrm{C}$ show that lland and arable negatively affect the share of the services sector whereas lpop positively affects the share of services except for three quantiles in the quantile regression with fundamental variables only. The dependency ratio has a largely insignificant impact whereas the relation between GDP per capita and the share of services is not robust across estimation techniques. In the SUR model and for higher quantiles in the quantile regression model with policy variables the relation has an inverse Ushape whereas it is U-shaped in the panel fixed effects model. Among the policy variables the impact of edus is largely insignificant whereas greater openness seems to adversely affect the share of services in output. FDI and, to a greater extent, capital have significant positive impacts on the share of services. The reform dummy dum92 is always positive and significant whereas the country dummies are largely insignificant.

A key take away from Table 17 is the fragile relation between GDP per capita and the shares of various sectors in aggregate output. For agriculture this relation is largely U-shaped whereas it should have been monotonically declining. This U-shaped relation also obtains in the case of the manufacturing sector whereas it should have been monotonically rising or, at least, and inverted U-shaped relation. Among the policy variables whereas greater openness increases the share of agriculture it reduces that of the services sector and largely has no effect on manufacturing. FDI has an insignificant effect on the share of agriculture whereas it reduces the share of the manufacturing sector, at least in some models. FDI has a weakly positive effect on the share of services. Capital investment, on the other hand, positively affects the share of manufacturing and services and reduces that of agriculture. The impact of educs is largely insignificant. The reforms beginning 1992 have positively affected the share of manufacturing and services, at least in some estimated equations. 


\section{Concluding remarks}

This paper models the evolution and determinants of the shares of agricultural, manufacturing and services sectors' value added for 4 South Asian countries for 55 years: 1960-2014. A number of alternative estimation techniques were used. These included pooled OLS without and with clustered standard errors, SUR estimates, quantile regressions and panel data techniques.

Determinants of these shares were classified into three broad categories "fundamentals", "policy" and "regional dummies". In general the estimated models fit the data well. In most cases quantile regressions unmasks facts that are not apparent in the OLS regression. estimates.

Policy conclusions are derived from the viewpoint of increasing the shares of the services and, particularly, the manufacturing sector in value added. We find that enhanced availability of electrical power and higher capital investment are central to the enhancement of the share of the manufacturing sector in value added. The relationships of the shares with GDP per capita are fragile and, sometimes, counter-intuitive.

It is a matter of concern that the impacts of key policy variables such as educs, fdi and open are not robust across the models and in, some instances, have the "wrong" sign even when significant. This calls for policy reform in these areas. For instance, Jha (2014) reports that secondary school enrolment and attainment in India lag behind several countries. There is substantial evidence to suggest that the quality of education needs to be improved. The impact of FDI reveals that the form and direction of FDI need to be thought through. The sign of "open" reveals that the engagement of India's international trade sector (exports and imports) need to be better integrated with industrial and services sector growth policies. Similar comments might apply to the other South Asian countries studied in this paper.

It seems that South Asia has undergone a period of arrested industrial development. There is urgent need for policy intervention if this condition is to be redressed. 


\section{References}

Clark, T. and D. Linzer (2012) “Should I use Fixed or Random Effects?’ mimeo Emory University.

Dabla-Norris, E., Thomas, A. Garcia-Verdu, R. and Y. Chen (2013) "Benchmarking Structural transformation across the World” IMF Working Paper WP/13/76, Washington DC.

Echevarria, C. (1997) "Changes in Sectoral Composition associated with economic growth" International Economic Review, vol. 38, no.2, pp.431-452.

Greene, W. (2008) Econometric Analysis, sixth edition, Princeton, New Jersey: Pearson, Prentice-Hall.

Jha, R. (2014) "Productive Employment and Empowering Education: An Agenda for India's Youth” Yojana, vol. 58, no.4, pp. 13-19.

Kochhar, K., Kumar, U. Rajan, R., Subramanian, A. and I. Tokatlidis (2002) “India's Pattern of Development: What Happened, What Follows?” IMF Working Paper WP/02/22, Washington DC: International Monetary Fund.

Kuznets, S. (1966) Modern Economic Growth: Rate, Structure, and Spread, Yale University Press, New Haven, Conn.

Kuznets, S. (1973) "Modern Economic Growth: Findings and Reflections" Nobel Lecture, American Economic Review, vol. 63, no. 2, pp. 247-258.

Machado, J.A.F. Machado, Parente, P.M.D. and J.M.C. Santos Silva, (2011). "QREG2: Stata module to perform quantile regression with robust and clustered standard errors," Statistical Software Components S457369, Boston College Department of Economics, revised 07 Feb 2015.

McManus, P. (2011) "Introduction to Regression Models for Panel Data Analysis" Mimeographed Class Notes Indiana University. 
Timmer, P., McMillan, M., Badiane, O., Rodrik, D., Binswanger-Mkhize, B. and F. Wouterse (2012) "Patterns of Growth and Structural Transformation in Africa: Trends and Lessons for Future Development Strategies" Washington DC: International Food Policy Research Institute.

Figure 1: Sectoral Share of Output and GDP growth

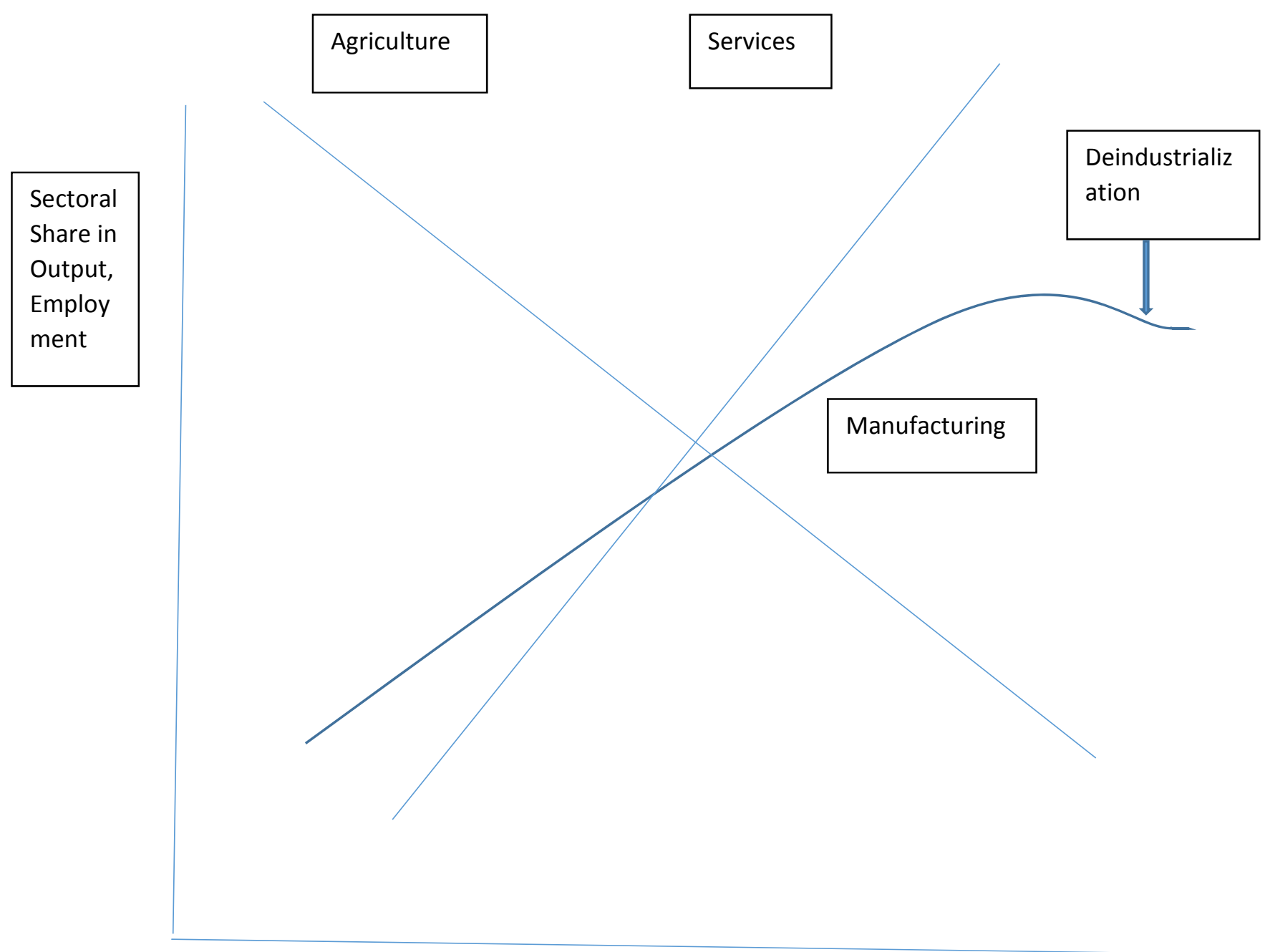

Time, GDP per capita 
Figure 2: Links between sectoral shares of output and GDP per capita: South Asia and individual countries

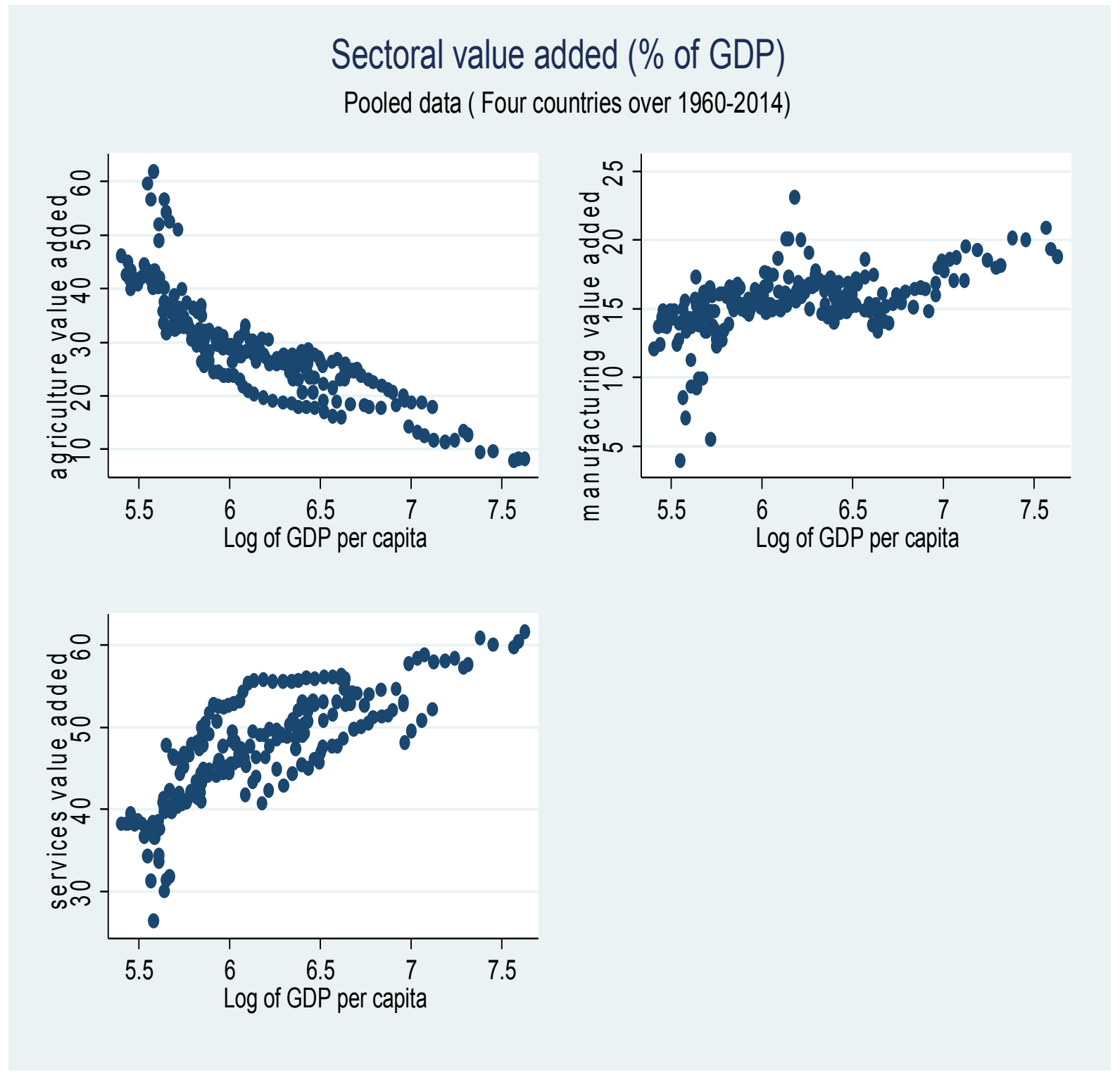


Sectoral value added (\% of GDP)
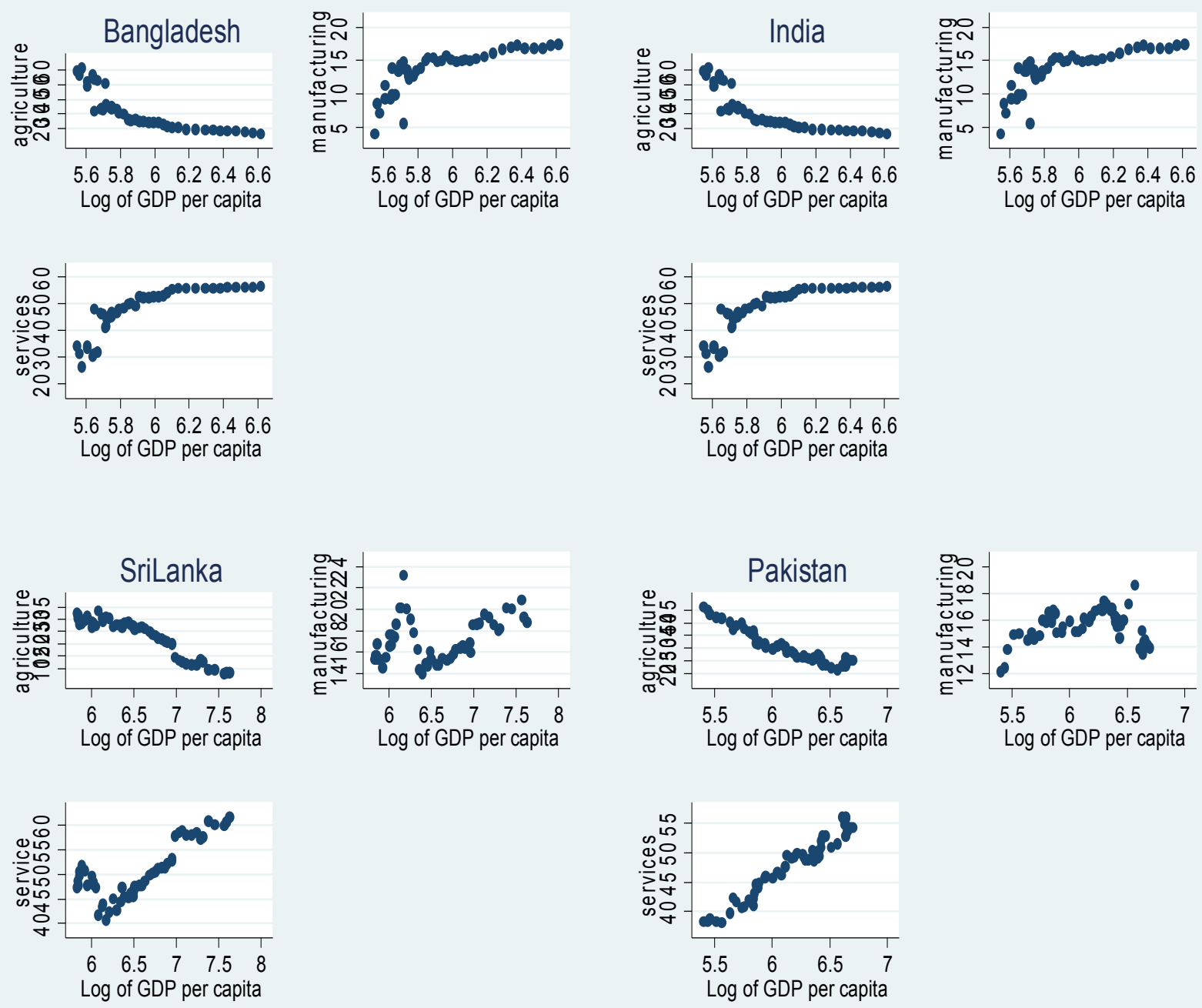


\section{Figure 3 Quantiles of shares of agriculture, manufacturing and services}
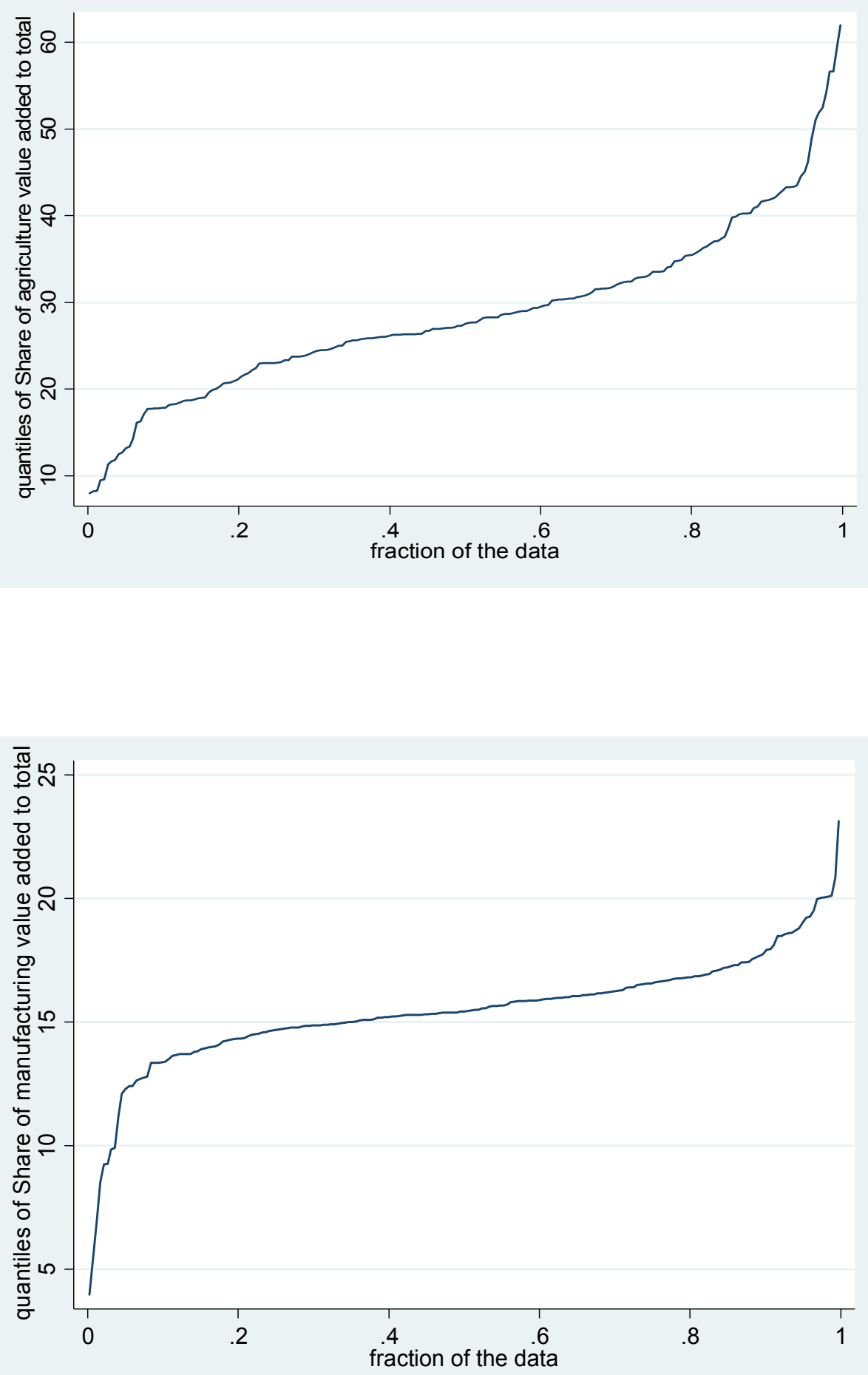
ASARC Working Paper 2016/01

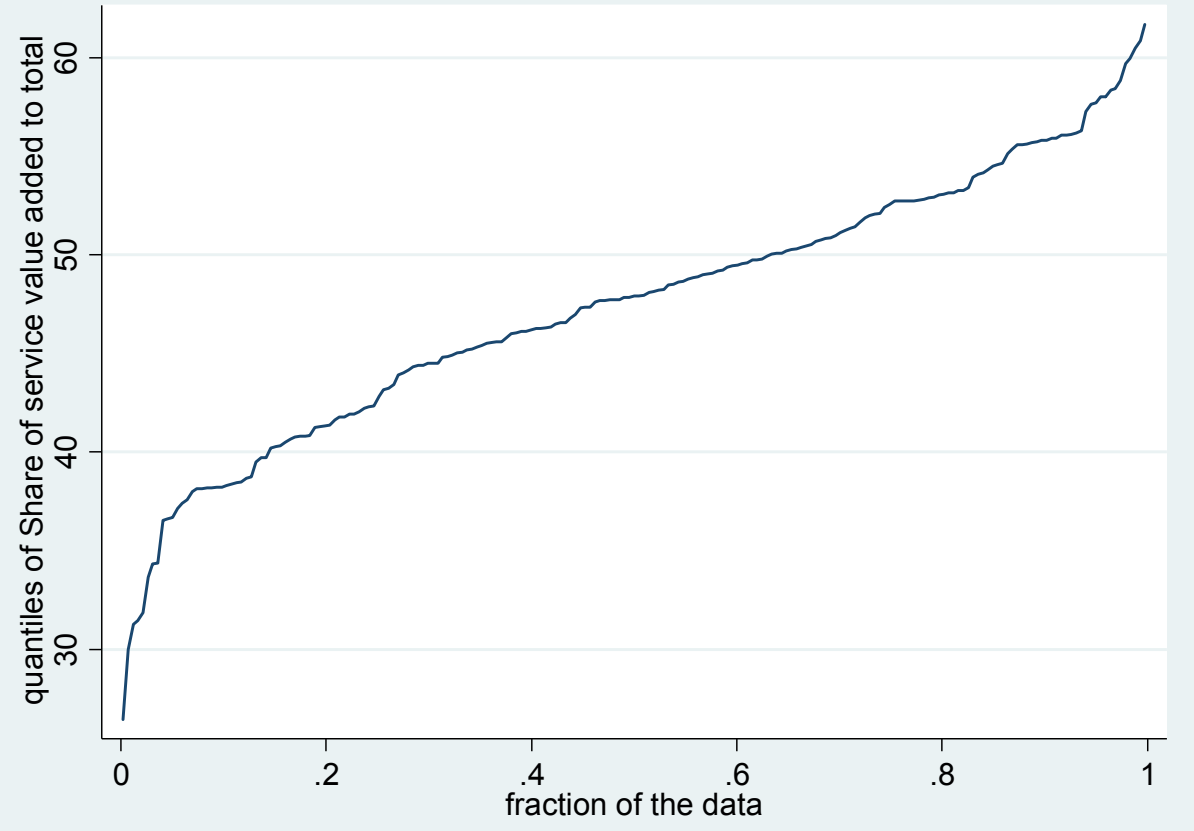


Figure 4: Plots of Quantile regression coefficients for the share of agriculture
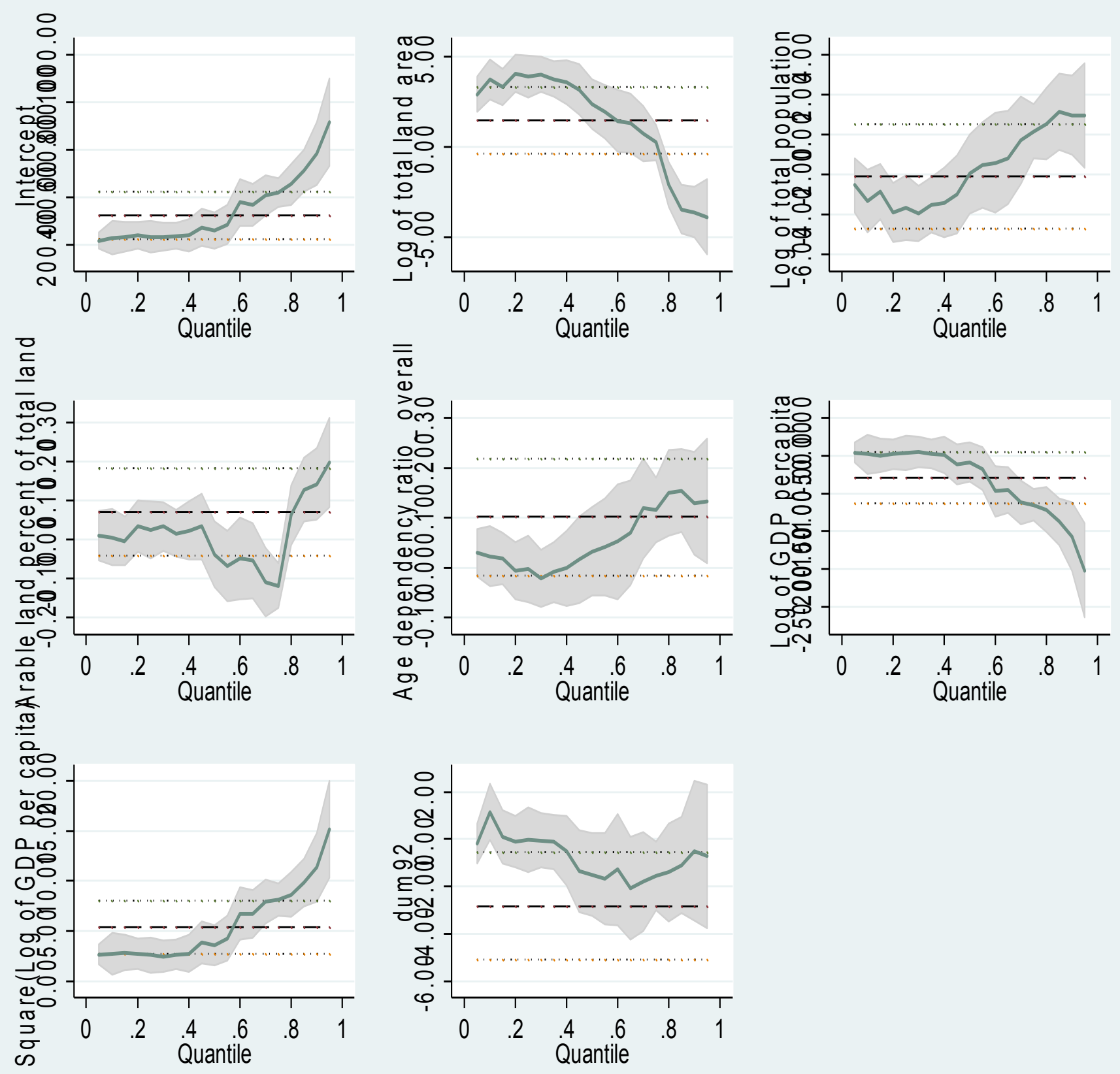

Agri equation: OLS coefficients and plot of coefficients across quantiles 
ASARC Working Paper 2016/01 
Figure 4: Plots of Quantile regression coefficients for the share of manufactures
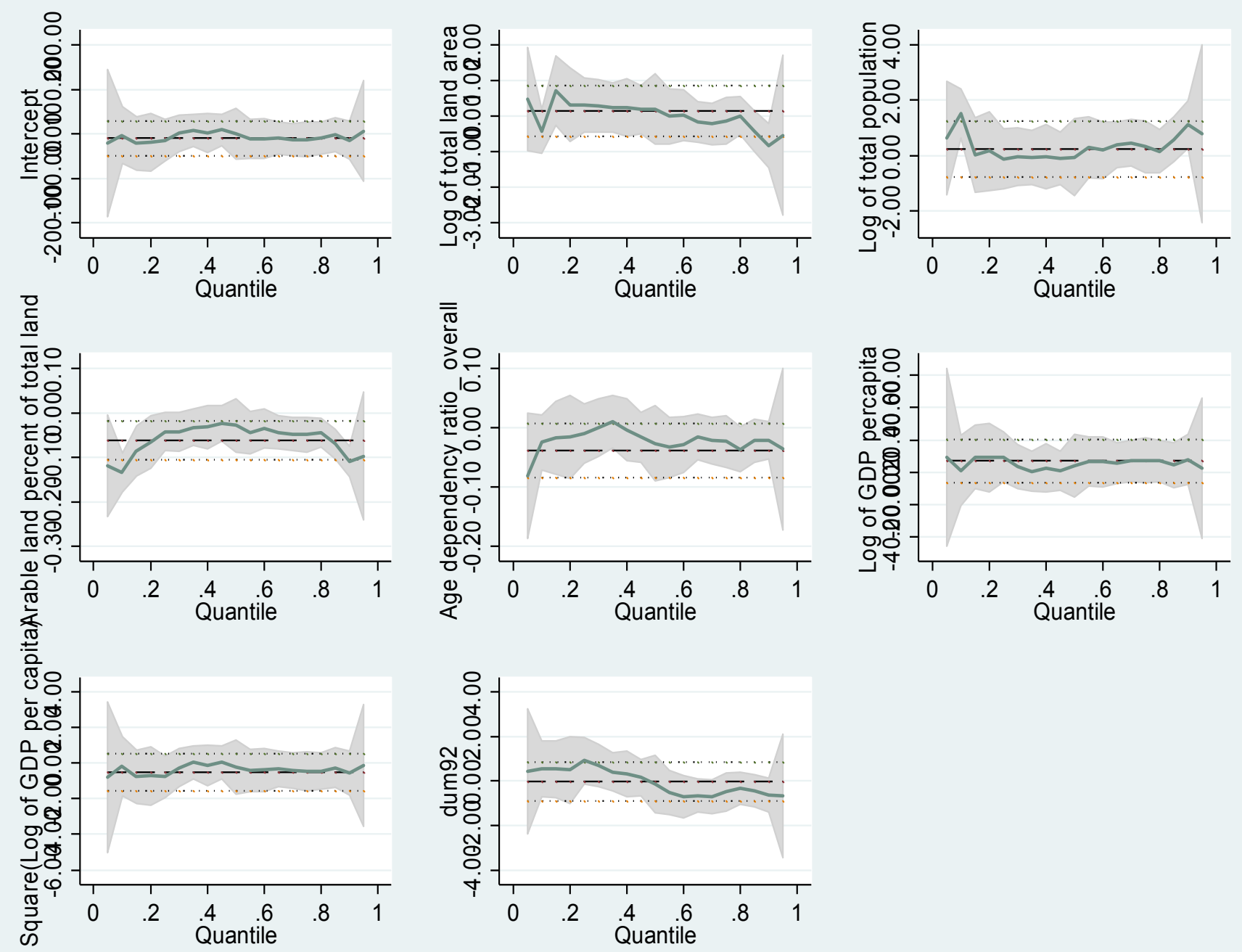

Manufacturing equation: OLS coefficients and plot of coefficients across quantiles 
Figure 5: Plots of Quantile regression coefficients for the share of services
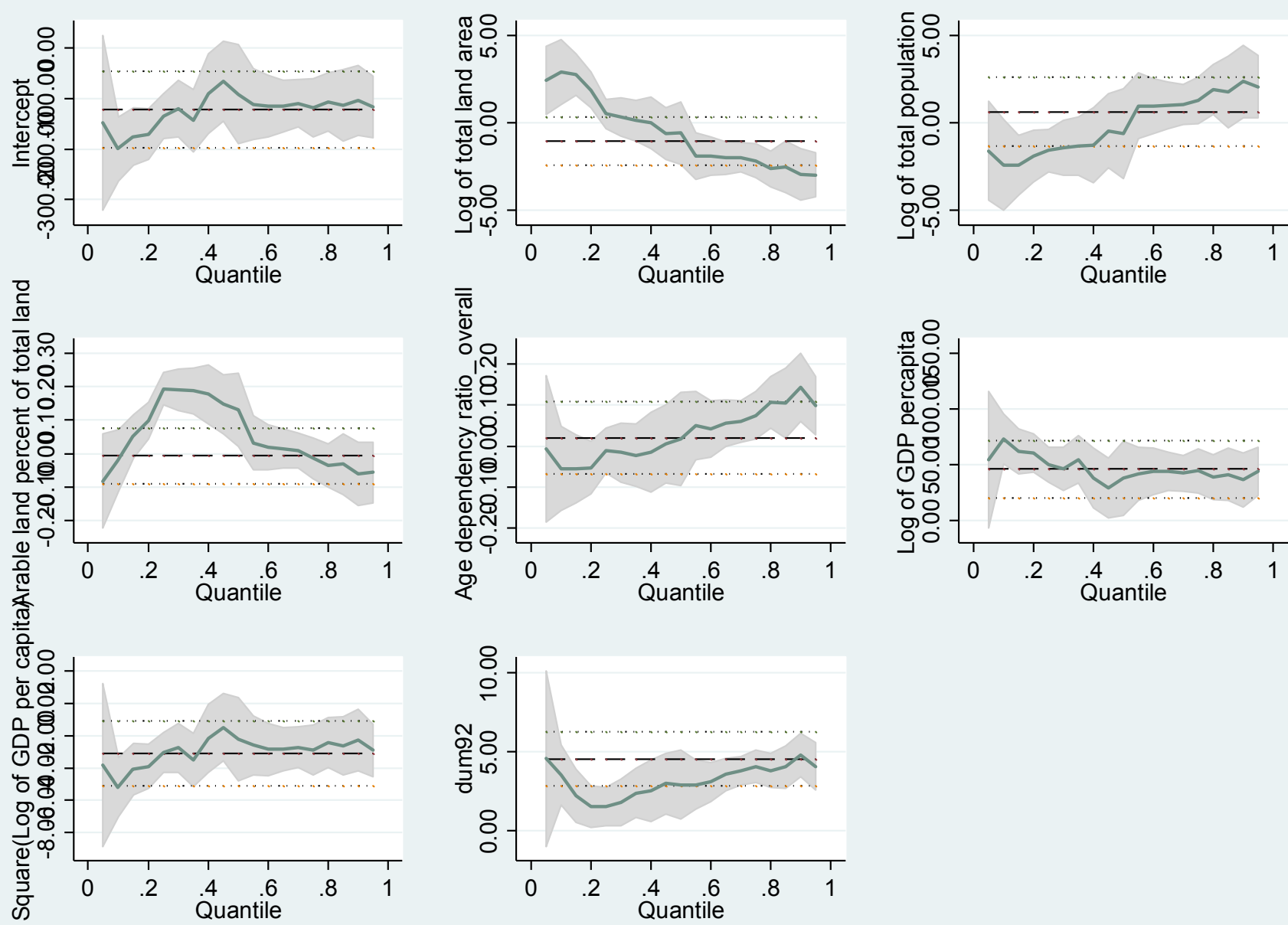

Service equation: OLS coefficients and plot of coefficients across quantiles 
Table 1: Summary Statistics of Variables

\begin{tabular}{|c|c|c|c|c|c|c|c|c|}
\hline \multicolumn{2}{|c|}{ Variable } & Mean & Std. Dev. & Min & $\operatorname{Max}$ & \multicolumn{3}{|c|}{ Observations } \\
\hline \multirow[t]{3}{*}{ cid } & overall & 2.578947 & 1.094012 & 1 & 4 & $\mathrm{~N}$ & $=$ & 209 \\
\hline & between & & 1.290994 & 1 & 4 & $\mathrm{n}$ & $=$ & 4 \\
\hline & within & & 0 & 2.578947 & 2.578947 & T-bar & $=$ & 52.25 \\
\hline \multirow[t]{3}{*}{ Time } & overall & 1988.158 & 15.46177 & 1960 & 2014 & $\mathrm{~N}$ & $=$ & 209 \\
\hline & between & & 2.75 & 1987 & 1992.5 & $n$ & $=$ & 4 \\
\hline & within & & 15.29753 & 1961.158 & 2015.158 & T-bar & $=$ & 52.25 \\
\hline \multirow[t]{3}{*}{ agri } & overall & 28.77806 & 9.712542 & 7.99197 & 61.95414 & $\mathrm{~N}$ & $=$ & 209 \\
\hline & between & & 3.733862 & 23.38173 & 31.49922 & $n$ & $=$ & 4 \\
\hline & within & & 9.145816 & 13.38783 & 59.23297 & T-bar & $=$ & 52.25 \\
\hline \multirow[t]{3}{*}{ manuf } & overall & 15.46577 & 2.307962 & 3.983848 & 23.1317 & $\mathrm{~N}$ & $=$ & 209 \\
\hline & between & & 1.416196 & 13.58574 & 17.05054 & $n$ & $=$ & 4 \\
\hline & within & & 1.9782 & 5.863875 & 21.54693 & T-bar & $=$ & 52.25 \\
\hline \multirow[t]{3}{*}{ service } & overall & 47.41743 & 6.634936 & 26.43481 & 61.6563 & $\mathrm{~N}$ & $=$ & 209 \\
\hline & between & & 2.386212 & 44.51427 & 50.35775 & $\mathrm{n}$ & $=$ & 4 \\
\hline & within & & 6.285369 & 26.52024 & 58.71597 & T-bar & $=$ & 52.25 \\
\hline \multirow[t]{3}{*}{ lland } & overall & 12.87152 & 1.532132 & 11.04628 & 14.90515 & $\mathrm{~N}$ & $=$ & 206 \\
\hline & between & & 1.743872 & 11.04628 & 14.90515 & $\mathrm{n}$ & $=$ & 4 \\
\hline & within & & 0 & 12.87152 & 12.87152 & T-bar & $=$ & 51.5 \\
\hline \multirow[t]{3}{*}{ lpop } & overall & 18.47975 & 1.466722 & 16.10764 & 20.982 & $\mathrm{~N}$ & $=$ & 209 \\
\hline & between & & 1.605428 & 16.5663 & 20.49403 & $\mathrm{n}$ & $=$ & 4 \\
\hline & within & & .3266766 & 17.73541 & 19.1513 & T-bar & $=$ & 52.25 \\
\hline \multirow[t]{3}{*}{ arable } & overall & 42.61197 & 19.27306 & 9.201084 & 73.38865 & $N$ & $=$ & 202 \\
\hline & between & & 22.26838 & 14.54464 & 66.43173 & $n$ & $=$ & 4 \\
\hline & within & & 2.466456 & 35.10319 & 49.56889 & $\mathrm{~T}$ & $=$ & 50.5 \\
\hline \multirow[t]{3}{*}{ age } & overall & 73.24309 & 12.84571 & 48.0156 & 93.28597 & $\mathrm{~N}$ & $=$ & 209 \\
\hline & between & & 8.126297 & 63.57941 & 82.12686 & $n$ & $=$ & 4 \\
\hline & within & & 10.65695 & 49.35309 & 97.17642 & T-bar & $=$ & 52.25 \\
\hline \multirow[t]{3}{*}{$\operatorname{lgdp}$} & overall & 6.180747 & $.50 \odot 2599$ & 5.404655 & 7.629951 & $\mathrm{~N}$ & $=$ & 208 \\
\hline & between & & .2811167 & 5.931473 & 6.568963 & $n$ & $=$ & 4 \\
\hline & within & & .4372369 & 5.431594 & 7.272775 & T-bar & $=$ & 52 \\
\hline \multirow[t]{3}{*}{ lgdpsq } & overall & 38.45069 & 6.355676 & 29.21029 & 58.21615 & $N$ & $=$ & 208 \\
\hline & between & & 3.584423 & 35.27247 & 43.42318 & $n$ & $=$ & 4 \\
\hline & within & & 5.548862 & 29.05773 & 53.24366 & T-bar & $=$ & 52 \\
\hline \multirow[t]{3}{*}{ educs } & overall & 40.53971 & 20.58214 & 15.84216 & 99.33851 & $\mathrm{~N}$ & $=$ & 123 \\
\hline & between & & 18.9284 & 22.80935 & 67.31642 & $n$ & $=$ & 4 \\
\hline & within & & 13.18538 & 19.13425 & 72.5618 & $\mathrm{~T}$ & $=$ & 30.75 \\
\hline \multirow[t]{3}{*}{ lpower } & overall & 5.074122 & .9460251 & 2.351975 & 6.611693 & $\mathrm{~N}$ & $=$ & 168 \\
\hline & between & & .7250417 & 4.022136 & 5.584971 & $\mathrm{n}$ & $=$ & 4 \\
\hline & within & & .705931 & 3.403961 & 6.681747 & $\mathrm{~T}$ & $=$ & 42 \\
\hline \multirow[t]{3}{*}{ fdi } & overall & .6736017 & .7364278 & -.0632423 & 3.668323 & $\mathrm{~N}$ & $=$ & 173 \\
\hline & between & & .2420359 & .3300278 & .8977417 & $n$ & $=$ & 4 \\
\hline & within & & .7054958 & -.2538285 & 3.584911 & T-bar & $=$ & 43.25 \\
\hline \multirow[t]{3}{*}{ trade } & overall & 36.48305 & 20.70416 & 7.529721 & 88.63646 & $\mathrm{~N}$ & $=$ & 198 \\
\hline & between & & 19.78956 & 21.43615 & 65.27342 & $\mathrm{n}$ & $=$ & 4 \\
\hline & within & & 11.1273 & 14.21946 & 70.5919 & $\mathrm{~T}$-bar & $=$ & 49.5 \\
\hline
\end{tabular}




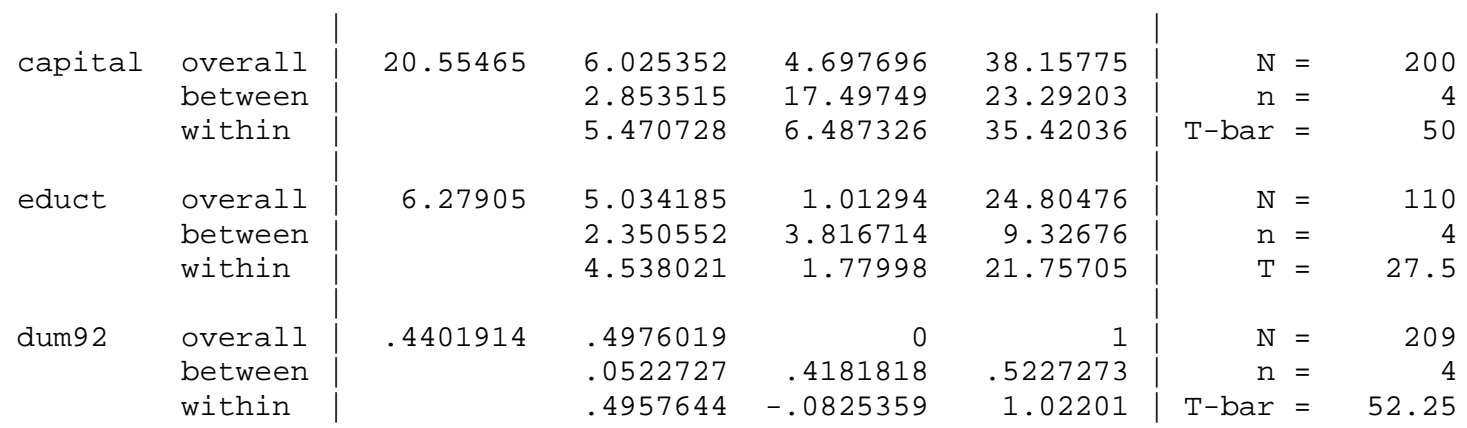

Table 2: Basic Statistics for selected countries

\section{Bangladesh}

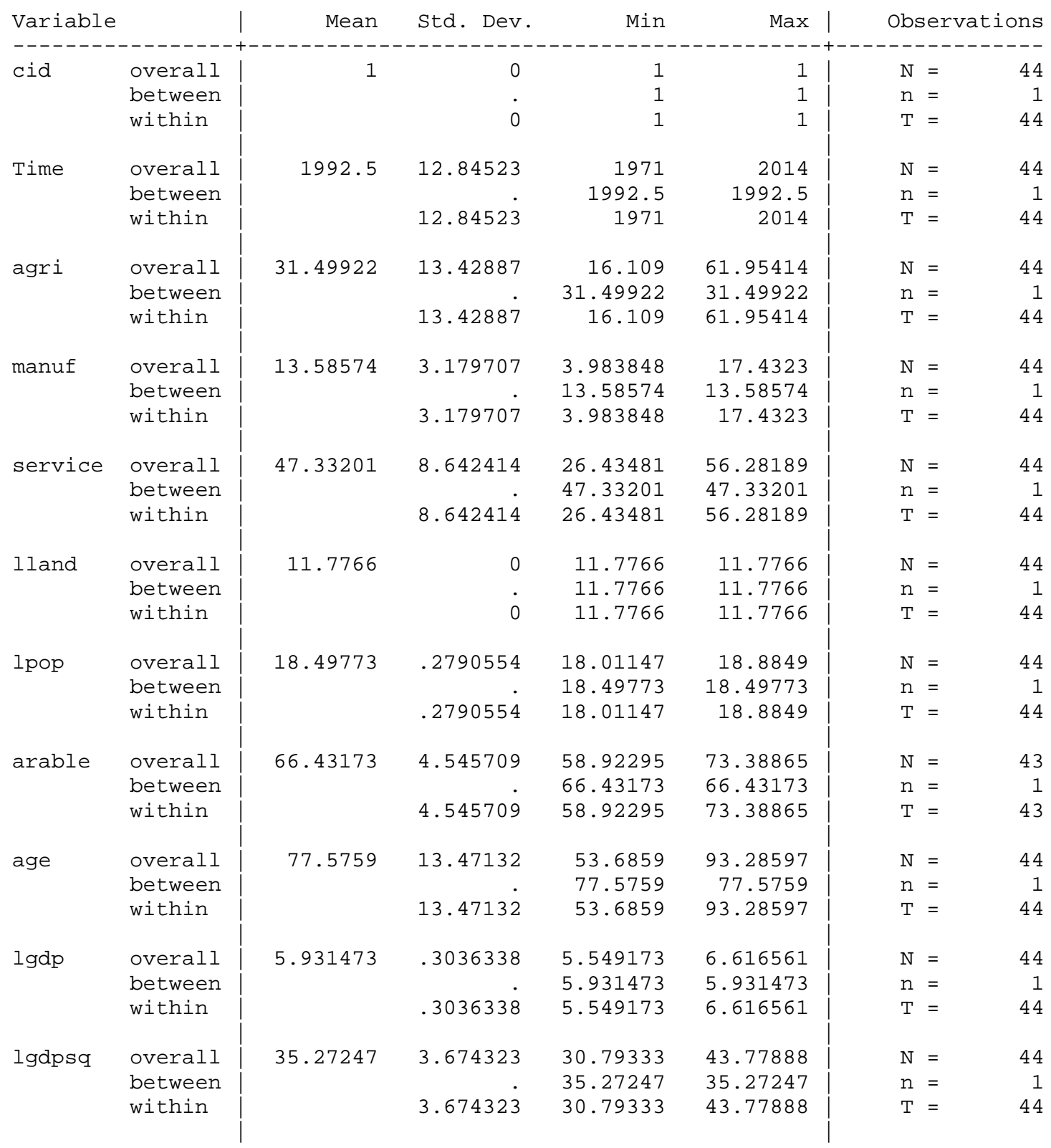


ASARC Working Paper 2016/01

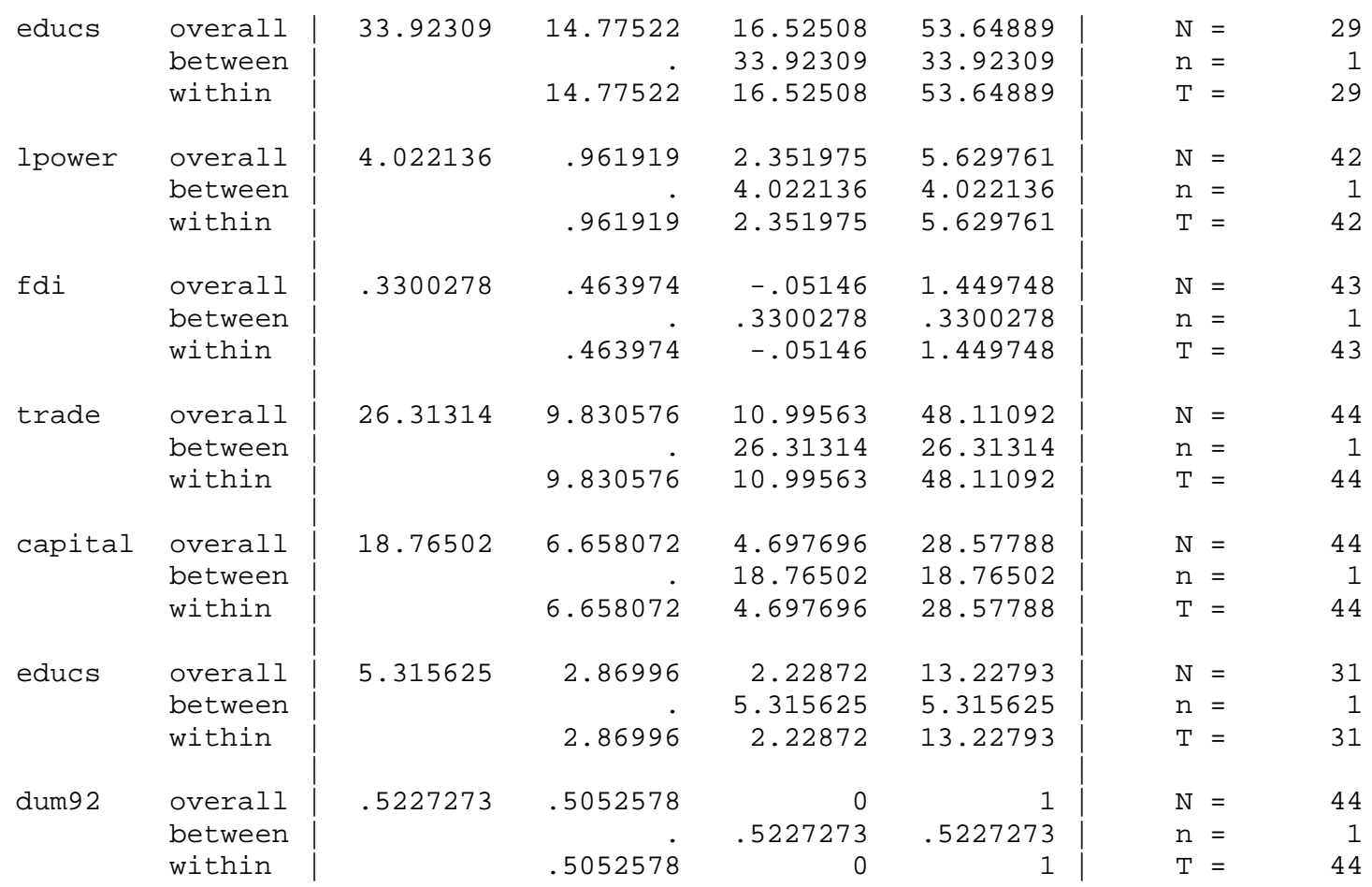

\section{India}

\begin{tabular}{|c|c|c|c|c|c|c|c|}
\hline Variable & & Mean & Std. Dev. & Min & $\operatorname{Max}$ & Obse & ons \\
\hline cid & overall & 2 & $\odot$ & 2 & 2 & $\mathrm{~N}=$ & 55 \\
\hline & between & & . & 2 & 2 & $\mathrm{n}=$ & 1 \\
\hline & within & & $\odot$ & 2 & 2 & $T=$ & 55 \\
\hline Time & overall & 1987 & 16.02082 & 1960 & 2014 & $\mathrm{~N}=$ & 55 \\
\hline & between & & & 1987 & 1987 & $\mathrm{n}=$ & 1 \\
\hline & within & & 16.02082 & 1960 & 2014 & $T=$ & 55 \\
\hline agri & overall & 30.69747 & 8.856152 & 17.73664 & 44.5262 & $N=$ & 55 \\
\hline & between & & & 30.69747 & 30.69747 & $\mathrm{n}$ & 1 \\
\hline & within & & 8.856152 & 17.73664 & 44.5262 & $T=$ & 55 \\
\hline manuf & overall & 15.38724 & 1.175347 & 12.42885 & 17.92443 & $\mathrm{~N}=$ & 55 \\
\hline & between & & & 15.38724 & 15.38724 & $\mathrm{n}=$ & 1 \\
\hline & within & & 1.175347 & 12.42885 & 17.92443 & $T=$ & 55 \\
\hline service & overall & 44.51427 & 5.832834 & 36.53333 & 54.63926 & $\mathrm{~N}=$ & 55 \\
\hline & between & & & 44.51427 & 44.51427 & $\mathrm{n}=$ & 1 \\
\hline & within & & 5.832834 & 36.53333 & 54.63926 & $T=$ & 55 \\
\hline lland & overall & 14.90515 & $\Theta$ & 14.90515 & 14.90515 & $\mathrm{~N}=$ & 54 \\
\hline & between & & . & 14.90515 & 14.90515 & $\mathrm{n}=$ & 1 \\
\hline & within & & $\odot$ & 14.90515 & 14.90515 & $T=$ & 54 \\
\hline lpop & overall & 20.49403 & .3271328 & 19.92401 & 20.982 & $\mathrm{~N}$ & 55 \\
\hline & between & & & 20.49403 & 20.49403 & $\mathrm{n}$ & 1 \\
\hline & within & & .3271328 & 19.92401 & 20.982 & $T=$ & 55 \\
\hline arable & overall & 54.03008 & .7680275 & 52.40365 & 55.03113 & $\mathrm{~N}$ & 53 \\
\hline & between & & & 54.03008 & 54.03008 & $\mathrm{n}$ & 1 \\
\hline & within & & .7680275 & 52.40365 & 55.03113 & $T=$ & 53 \\
\hline
\end{tabular}


ASARC Working Paper 2016/01

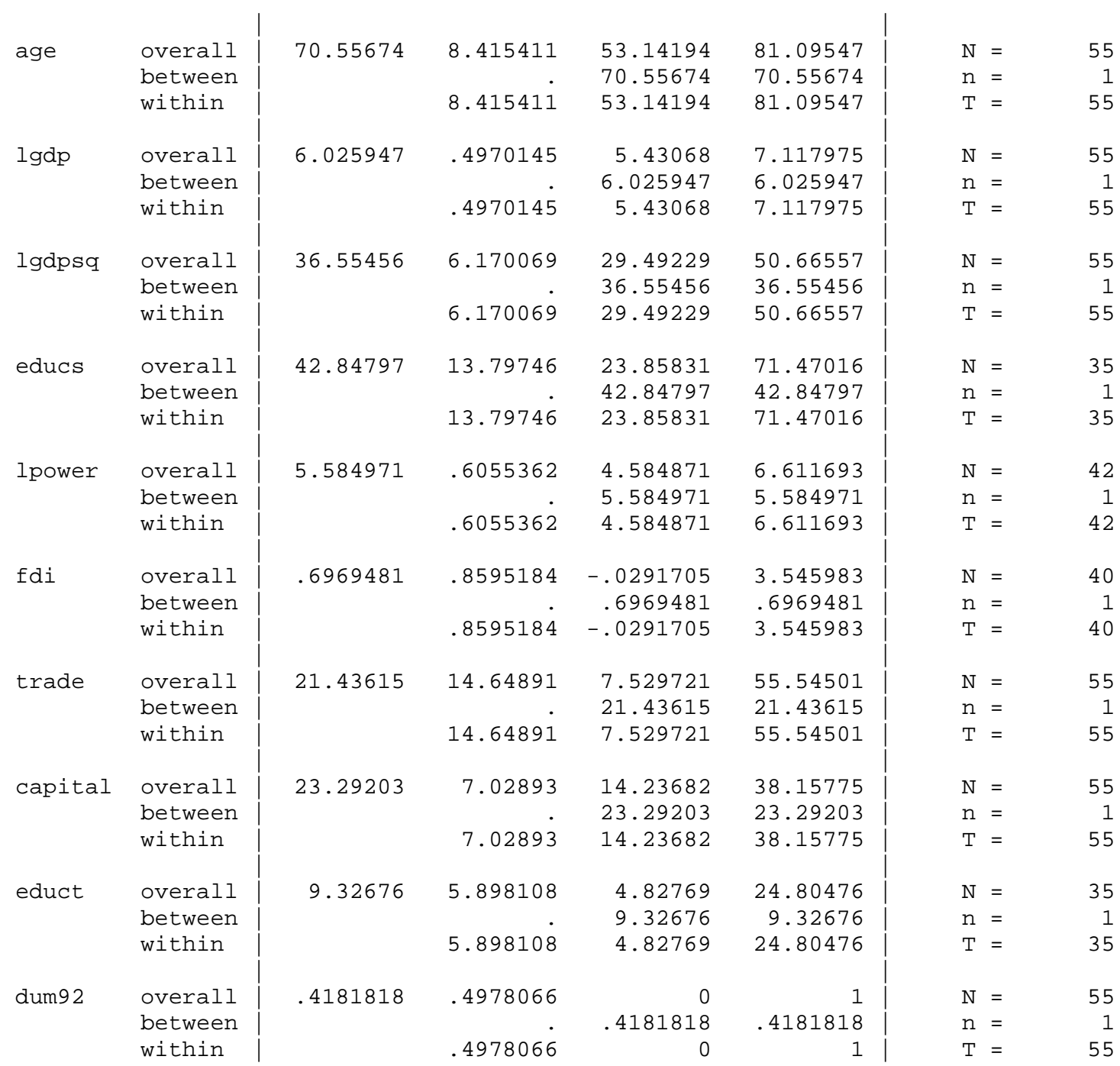

Sri Lanka

\begin{tabular}{|c|c|c|c|c|c|c|c|}
\hline Variable & & Mean & Std. Dev. & Min & $\operatorname{Max}$ & Obse & ions \\
\hline cid & overall & 3 & $\odot$ & 3 & 3 & $N=$ & 55 \\
\hline & between & & . & 3 & 3 & $\mathrm{n}=$ & \\
\hline & within & & $\odot$ & 3 & 3 & $\mathrm{~T}=$ & 5 \\
\hline Time & overall & 1987 & 16.02082 & 1960 & 2014 & $\mathrm{~N}=$ & \\
\hline & between & & & 1987 & 1987 & $\mathrm{n}=$ & \\
\hline & within & & 16.02082 & 1960 & 2014 & $T=$ & \\
\hline agri & overall & 23.38173 & 7.563865 & 7.99197 & 33.16453 & $\mathrm{~N}=$ & \\
\hline & between & & & 23.38173 & 23.38173 & $\mathrm{n}=$ & \\
\hline & within & & 7.563865 & 7.99197 & 33.16453 & $T=$ & \\
\hline manuf & overall & 17.05054 & 2.022371 & 14.01324 & 23.1317 & $\mathrm{~N}=$ & \\
\hline & between & & & 17.05054 & 17.05054 & $\mathrm{n}=$ & \\
\hline & within & & 2.022371 & 14.01324 & 23.1317 & $T=$ & \\
\hline service & overall & 50.35775 & 5.571179 & 40.63833 & 61.6563 & $N=$ & 55 \\
\hline & between & & & 50.35775 & 50.35775 & $\mathrm{n}$ & \\
\hline & within & & 5.571179 & 40.63833 & 61.6563 & $T=$ & \\
\hline
\end{tabular}


ASARC Working Paper 2016/01

\begin{tabular}{|c|c|c|c|c|c|c|}
\hline lland & $\begin{array}{l}\text { overall } \\
\text { between } \\
\text { within }\end{array}$ & 11.04628 & $\begin{array}{l}\dot{\theta} \\
\dot{\theta}\end{array}$ & $\begin{array}{l}11.04628 \\
11.04628 \\
11.04628\end{array}$ & $\begin{array}{l}11.04628 \\
11.04628 \\
11.04628\end{array}$ & $\begin{array}{l}\mathrm{N} \\
\mathrm{n} \\
\mathrm{T}\end{array}$ \\
\hline lpop & $\begin{array}{l}\text { overall } \\
\text { between } \\
\text { within }\end{array}$ & 16.5663 & $\begin{array}{r}.2211298 \\
.2211298\end{array}$ & $\begin{array}{r}16.10764 \\
16.5663 \\
16.10764\end{array}$ & $\begin{array}{r}16.85378 \\
16.5663 \\
16.85378\end{array}$ & $\begin{array}{l}\mathrm{N} \\
\mathrm{n} \\
\mathrm{T}\end{array}$ \\
\hline arable & $\begin{array}{l}\text { overall } \\
\text { between } \\
\text { within }\end{array}$ & 14.54464 & $\begin{array}{r}2.275205 \\
2.275205\end{array}$ & $\begin{array}{l}9.201084 \\
14.54464 \\
9.201084\end{array}$ & $\begin{array}{l}20.73035 \\
14.54464 \\
20.73035\end{array}$ & $\begin{array}{l}\mathrm{N} \\
\mathrm{n} \\
\mathrm{T}\end{array}$ \\
\hline age & $\begin{array}{l}\text { overall } \\
\text { between } \\
\text { within }\end{array}$ & 63.57941 & $\begin{array}{r}13.02516 \\
13.02516\end{array}$ & $\begin{array}{r}48.0156 \\
63.57941 \\
48.0156\end{array}$ & $\begin{array}{l}87.51274 \\
63.57941 \\
87.51274\end{array}$ & $\begin{array}{l}\mathrm{N} \\
\mathrm{n} \\
\mathrm{T}\end{array}$ \\
\hline $\operatorname{lgdp}$ & $\begin{array}{l}\text { overall } \\
\text { between } \\
\text { within }\end{array}$ & 6.568963 & $\begin{array}{r}.5263414 \\
.5263414\end{array}$ & $\begin{array}{l}5.833542 \\
6.568963 \\
5.833542\end{array}$ & $\begin{array}{l}7.629951 \\
6.568963 \\
7.629951\end{array}$ & $\begin{array}{l}\mathrm{N} \\
\mathrm{n} \\
\mathrm{T}\end{array}$ \\
\hline lgdpsq & $\begin{array}{l}\text { overall } \\
\text { between } \\
\text { within }\end{array}$ & 43.42318 & $\begin{array}{r}7.016064 \\
7.016064\end{array}$ & $\begin{array}{l}34.03022 \\
43.42318 \\
34.03022\end{array}$ & $\begin{array}{l}58.21615 \\
43.42318 \\
58.21615\end{array}$ & $\begin{array}{l}\mathrm{N} \\
\mathrm{n} \\
\mathrm{T}\end{array}$ \\
\hline educs & $\begin{array}{l}\text { overall } \\
\text { between } \\
\text { within }\end{array}$ & 67.31642 & $\begin{array}{r}16.65485 \\
16.65485\end{array}$ & $\begin{array}{l}45.91096 \\
67.31642 \\
45.91096\end{array}$ & $\begin{array}{l}99.33851 \\
67.31642 \\
99.33851\end{array}$ & $\begin{array}{l}\mathrm{N} \\
\mathrm{n} \\
\mathrm{T}\end{array}$ \\
\hline lpower & $\begin{array}{l}\text { overall } \\
\text { between } \\
\text { within }\end{array}$ & 5.167207 & $\begin{array}{r}.6548636 \\
.6548636\end{array}$ & $\begin{array}{l}4.059056 \\
5.167207 \\
4.059056\end{array}$ & $\begin{array}{r}6.26684 \\
5.167207 \\
6.26684\end{array}$ & $\begin{array}{l}\mathrm{N} \\
\mathrm{n} \\
\mathrm{T}\end{array}$ \\
\hline fdi & $\begin{array}{l}\text { overall } \\
\text { between } \\
\text { within }\end{array}$ & .8977417 & $\begin{array}{r}.6393539 \\
.6393539\end{array}$ & $\begin{array}{r}-.0296885 \\
.8977417 \\
-.0296885\end{array}$ & $\begin{array}{l}2.849577 \\
.8977417 \\
2.849577\end{array}$ & $\begin{array}{l}\mathrm{N} \\
\mathrm{n} \\
\mathrm{T}\end{array}$ \\
\hline trade & $\begin{array}{l}\text { overall } \\
\text { between } \\
\text { within }\end{array}$ & 65.27342 & $\begin{array}{r}12.4904 \\
12.4904\end{array}$ & $\begin{array}{l}43.00983 \\
65.27342 \\
43.00983\end{array}$ & $\begin{array}{l}88.63646 \\
65.27342 \\
88.63646\end{array}$ & $\begin{array}{l}\mathrm{N} \\
\mathrm{n} \\
\mathrm{T}\end{array}$ \\
\hline capital & $\begin{array}{l}\text { overall } \\
\text { between } \\
\text { within }\end{array}$ & 22.64879 & $\begin{array}{r}5.038668 \\
5.038668\end{array}$ & $\begin{array}{l}12.53093 \\
22.64879 \\
12.53093\end{array}$ & $\begin{array}{l}33.76824 \\
22.64879 \\
33.76824\end{array}$ & $\begin{array}{l}\mathrm{N} \\
\mathrm{n} \\
\mathrm{T}\end{array}$ \\
\hline educs & $\begin{array}{l}\text { overall } \\
\text { between } \\
\text { within }\end{array}$ & 5.476669 & $\begin{array}{r}6.118138 \\
6.118138\end{array}$ & $\begin{array}{r}1.01294 \\
5.476669 \\
1.01294\end{array}$ & $\begin{array}{r}18.7629 \\
5.476669 \\
18.7629\end{array}$ & $\begin{array}{l}\mathrm{N} \\
\mathrm{n} \\
\mathrm{T}\end{array}$ \\
\hline dum92 & $\begin{array}{l}\text { overall } \\
\text { between } \\
\text { within }\end{array}$ & 4181818 & $\begin{array}{r}.4978066 \\
.4978066\end{array}$ & $\begin{array}{r}\odot \\
.4181818 \\
\odot\end{array}$ & $\begin{array}{r}1 \\
1\end{array}$ & $\begin{array}{l}\mathrm{N} \\
\mathrm{n} \\
\mathrm{T}\end{array}$ \\
\hline
\end{tabular}

Pakistan

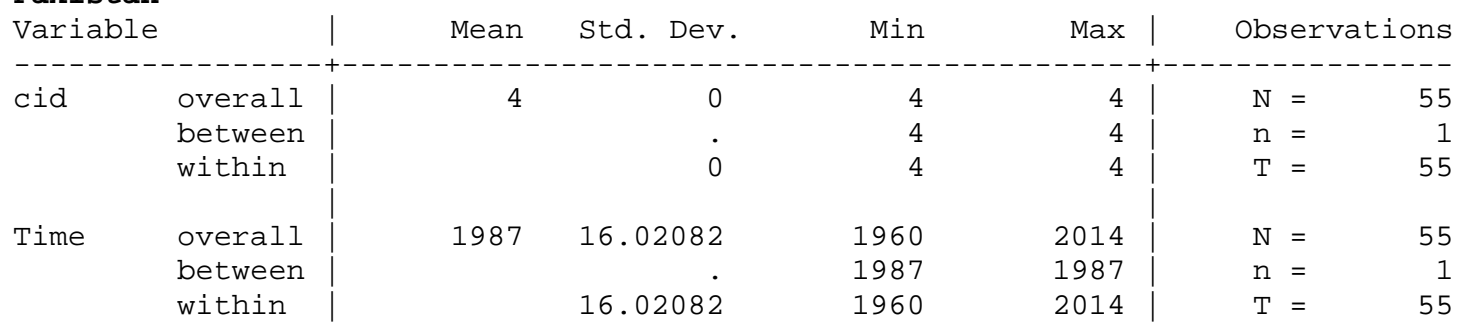


ASARC Working Paper 2016/01

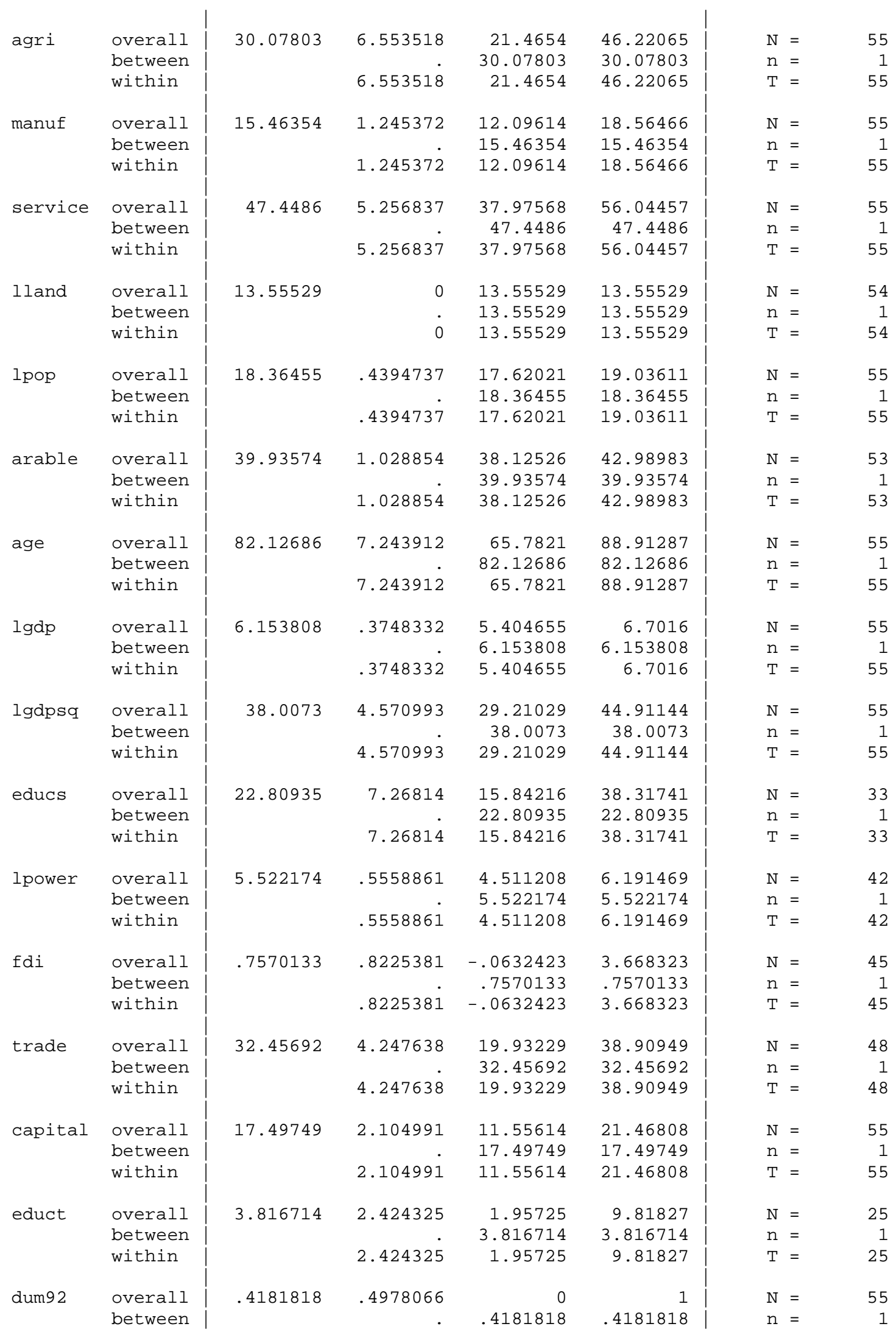


ASARC Working Paper 2016/01

within |

55 
Table 3: structural transformation base model: Role of country fundamentals

Pooled OLS including country dummies

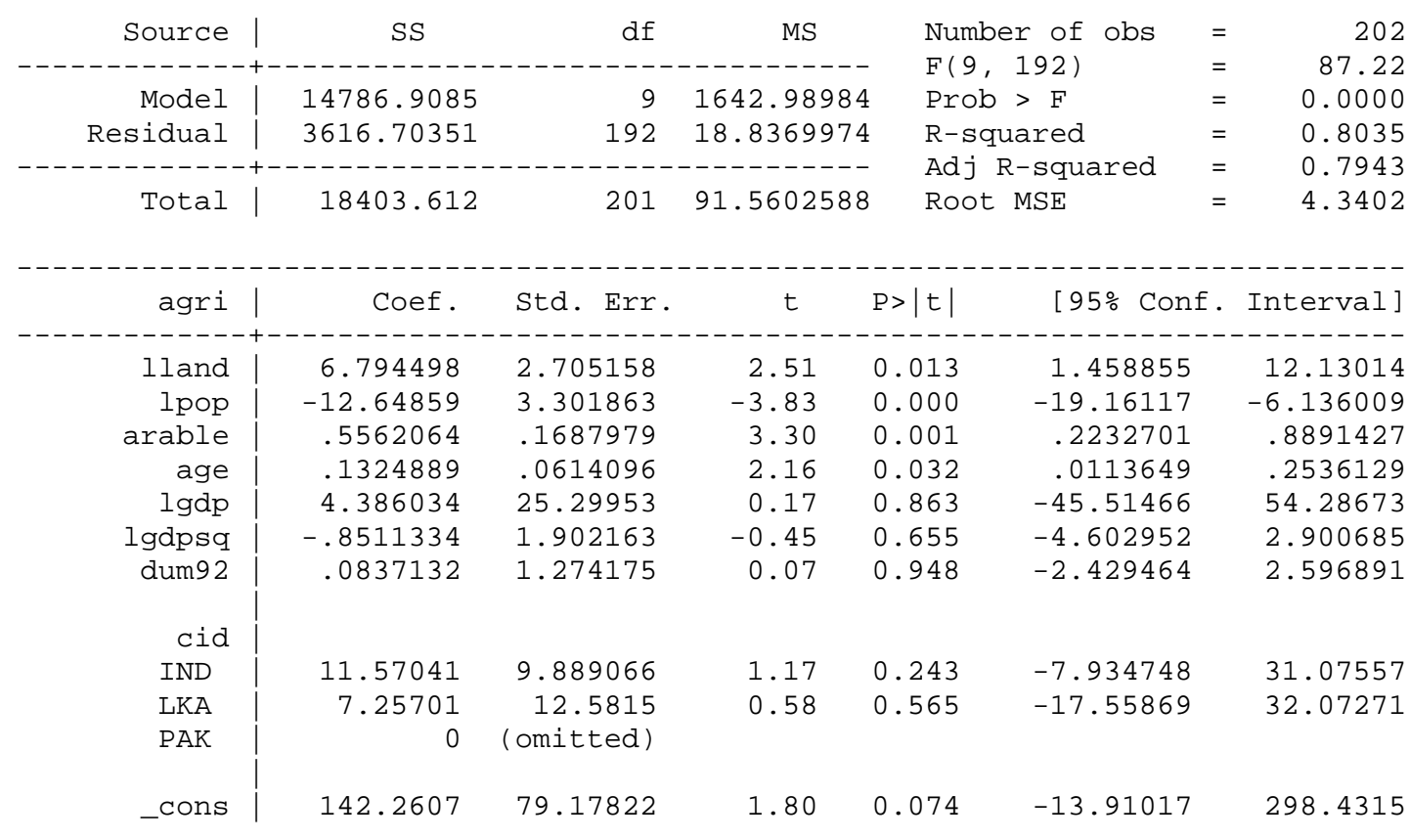

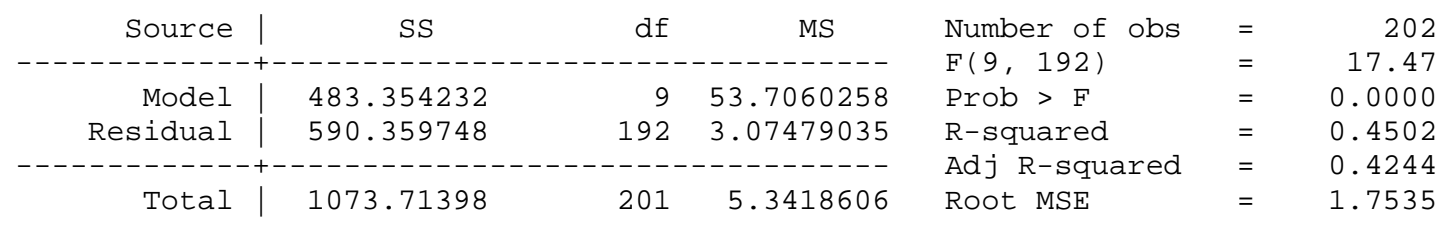

\begin{tabular}{|c|c|c|c|c|c|c|}
\hline manuf & Coef. & Std. Err. & $\mathrm{t}$ & $P>|t|$ & [95\% Conf. & Interval] \\
\hline & & & & & & 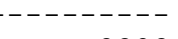 \\
\hline lland & -1.335502 & 1.092935 & -1.22 & 0.223 & -3.491204 & .8202 \\
\hline lpop & 2.702834 & 1.334016 & 2.03 & 0.044 & .0716267 & 5.334042 \\
\hline arable & -.1903421 & .0681976 & -2.79 & $\odot .006$ & -.3248547 & - . 0558295 \\
\hline age & -.0432537 & . 0248106 & -1.74 & 0.083 & - . . 0921901 & .0056827 \\
\hline $\operatorname{lgdp}$ & -13.23041 & 10.22149 & -1.29 & 0.197 & -33.39124 & 6.930427 \\
\hline lgdpsq & 1.025538 & .76851 & 1.33 & 0.184 & -.4902684 & 2.541345 \\
\hline dum92 & -.7493526 & .5147909 & -1.46 & 0.147 & -1.764724 & .266019 \\
\hline \multicolumn{7}{|l|}{ cid } \\
\hline IND & -2.150647 & 3.995372 & -0.54 & 0.591 & -10.0311 & 5.72981 \\
\hline LKA & -2.718554 & 5.083166 & -0.53 & 0.593 & -12.74457 & 7.307465 \\
\hline PAK & $\odot$ & (omitted) & & & & \\
\hline _cons & 37.95426 & 31.98951 & 1.19 & 0.237 & -25.14175 & 101.0503 \\
\hline
\end{tabular}

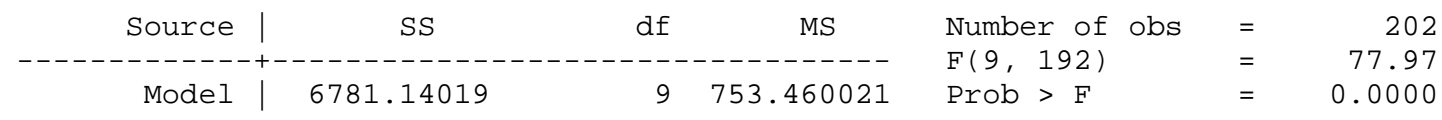


ASARC Working Paper 2016/01

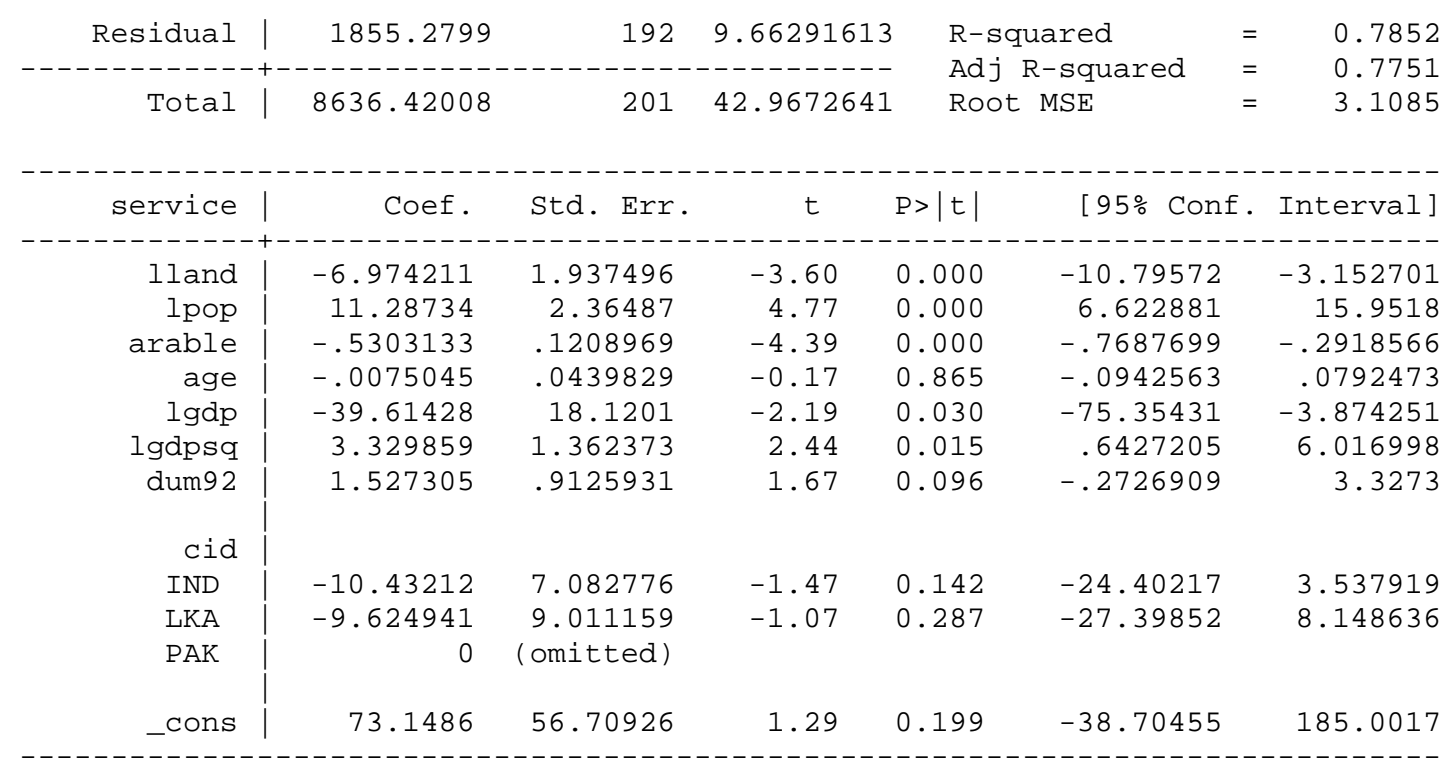




\section{Table 4: Pooled OLS with clustered (by cid) standard error}

Agriculture

Linear regression

$\begin{array}{llr}\text { Number of obs } & = & 202 \\ \mathrm{~F}(2,3) & = & \text {. } \\ \text { Prob > F } & = & 0.8035 \\ \text { R-squared } & = & 4.3402 \\ \text { Root MSE } & = & 4.04\end{array}$

(Std. Err. adjusted for 4 clusters in cid)

\begin{tabular}{|c|c|c|c|c|c|c|}
\hline agri & Coef. & $\begin{array}{l}\text { Robust } \\
\text { Std. Err. }\end{array}$ & $\mathrm{t}$ & $P>|t|$ & [95\% Conf. & Interval \\
\hline lland & 6.794498 & 6.103042 & 1.11 & 0.347 & -12.6281 & 26.2171 \\
\hline lpop & -12.64859 & 18.00877 & -0.70 & $\odot .533$ & -69.96055 & 44.66337 \\
\hline arable & .5562064 & .3473994 & 1.60 & $\odot .208$ & -.5493735 & 1.661786 \\
\hline age & .1324889 & .2290631 & 0.58 & 0.604 & -.5964922 & .86147 \\
\hline lgdp & 4.386034 & 121.0653 & 0.04 & 0.973 & -380.8976 & 389.6697 \\
\hline lgdpsq & -.8511334 & 8.936961 & -0.10 & 0.930 & -29.29253 & 27.59027 \\
\hline dum92 & .0837132 & .7934638 & 0.11 & 0.923 & -2.441443 & 2.608869 \\
\hline cid & & & & & & \\
\hline IND & 11.57041 & 46.96008 & 0.25 & 0.821 & -137.8775 & 161.0183 \\
\hline LKA & 7.25701 & 44.09507 & 0.16 & 0.880 & -133.0732 & 147.5872 \\
\hline PAK & 0 & (omitted) & & & & \\
\hline _cons & 142.2607 & 283.5184 & 0.50 & 0.650 & -760.0215 & 1044.543 \\
\hline
\end{tabular}

Manufacturing

Linear regression

$\begin{array}{llr}\text { Number of obs } & & 202 \\ \mathrm{~F}(2,3) & = & . \\ \text { Prob }>\mathrm{F} & = & . \\ \text { R-squared } & = & 0.4502 \\ \text { Root MSE } & = & 1.7535\end{array}$

(Std. Err. adjusted for 4 clusters in cid)

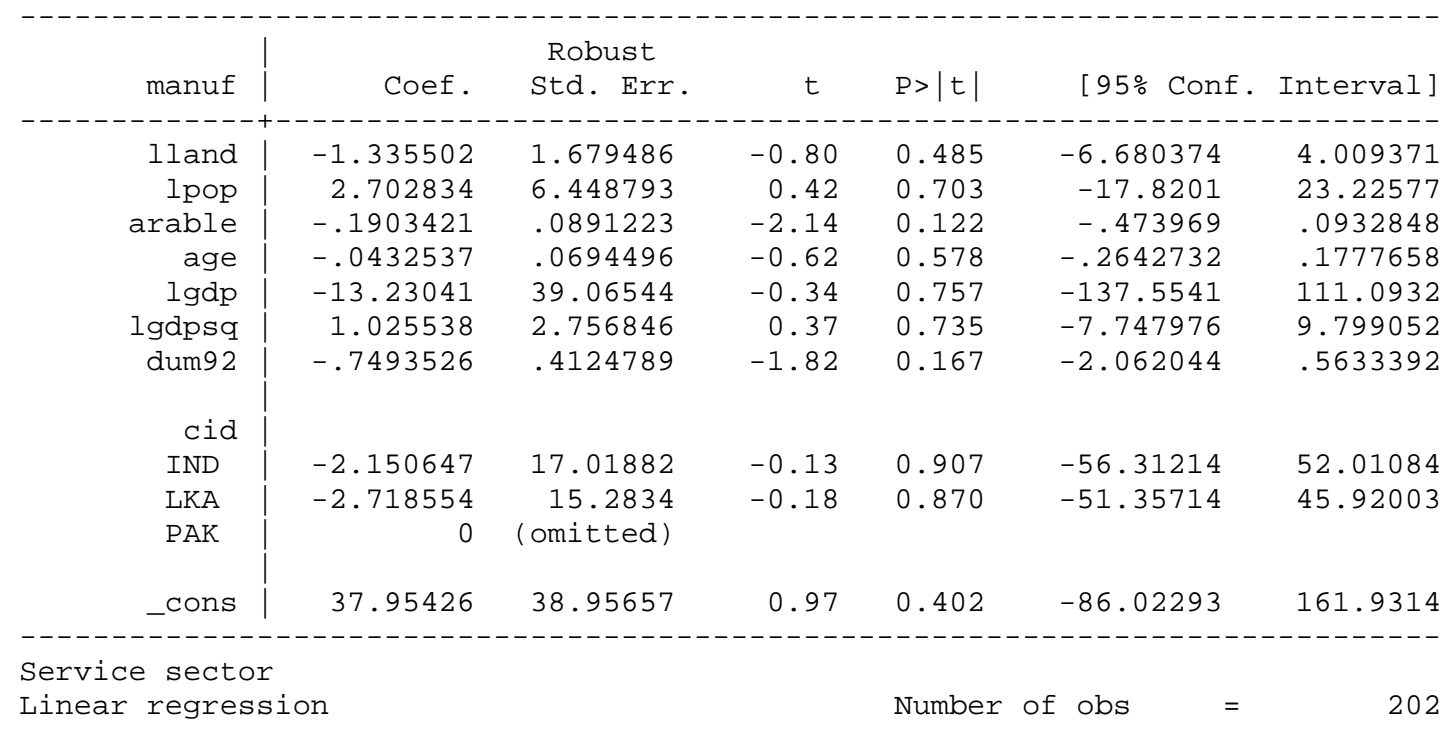


ASARC Working Paper 2016/01

$\begin{array}{lll}\mathrm{F}(2,3) & = & \\ \text { Prob }>\mathrm{F} & = & \\ \text { R-squared } & = & 0.7852 \\ \text { Root MSE } & = & 3.1085\end{array}$

(Std. Err. adjusted for 4 clusters in cid)

\begin{tabular}{|c|c|c|c|c|c|c|}
\hline service & Coef. & $\begin{array}{l}\text { Robust } \\
\text { Std. Err. }\end{array}$ & $\mathrm{t}$ & $P>|t|$ & [95\% Conf. & Interval] \\
\hline lland & -6.974211 & 5.525791 & -1.26 & ๑.296 & -24.55974 & 10.61132 \\
\hline lpop & 11.28734 & 8.813389 & 1.28 & $\odot .290$ & -16.7608 & 39.33548 \\
\hline arable & -.5303133 & .3549692 & -1.49 & 0.232 & -1.659984 & .599357 \\
\hline age & - . . 0075045 & .1783633 & -0.04 & 0.969 & -.5751362 & .5601272 \\
\hline $\operatorname{lgdp}$ & -39.61428 & 79.60703 & $-0.5 \odot$ & $\odot .653$ & -292.9594 & 213.7308 \\
\hline $\operatorname{lgdpsq}$ & 3.329859 & 6.100402 & 0.55 & 0.623 & -16.08434 & 22.74406 \\
\hline dum92 & 1.527305 & 1.677395 & 0.91 & 0.430 & -3.810915 & 6.865524 \\
\hline cid & & & & & & \\
\hline IND & -10.43212 & 23.86401 & -0.44 & 0.692 & -86.37806 & 65.51381 \\
\hline LKA & -9.624941 & 26.18088 & -0.37 & 0.738 & -92.94418 & 73.6943 \\
\hline PAK & $\odot$ & (omitted) & & & & \\
\hline _cons & 73.1486 & 248.2769 & 0.29 & 0.787 & -716.9794 & 863.2766 \\
\hline
\end{tabular}




\section{Table 5: Extended Structural Transformation Model: role of} policy variables.

(including country dummies)

\begin{tabular}{r|cccr} 
Agriculture \\
Source |
\end{tabular}

Manufacturing

\begin{tabular}{|c|c|c|c|c|c|c|}
\hline Source I & SS & $d f$ & MS & Number of obs & $=$ & 115 \\
\hline & & & --- & $F(14,100)$ & $=$ & 12.31 \\
\hline Model & 220.226469 & 14 & 15.7304621 & Prob $>F$ & $=$ & 0.000 \\
\hline Residual & 127.765836 & 100 & 1.27765836 & R-squared & $=$ & 0.632 \\
\hline Tot & 92305 & 114 & $\begin{array}{l}-\cdots \\
3.05256408\end{array}$ & Adj R-squared & $\begin{array}{l}= \\
=\end{array}$ & 0.581 \\
\hline
\end{tabular}

\begin{tabular}{|c|c|c|c|c|c|c|}
\hline manuf & Coef. & Std. Err. & $\mathrm{t}$ & $P>|t|$ & [95\% Conf & Interval] \\
\hline lland & -7.147127 & 1.343242 & -5.32 & $\odot . \odot \odot \odot$ & -9.81208 & -4.482174 \\
\hline lpop & -2.224222 & 1.69145 & -1.31 & $\odot .192$ & -5.580011 & 1.131567 \\
\hline arable & -.3299028 & .0815199 & -4.05 & $\odot . \odot \odot \odot$ & -.491636 & - . 1681697 \\
\hline age & .1537796 & .0449357 & 3.42 & $\odot .001$ & .0646284 & .2429307 \\
\hline lgdp & -59.11997 & 15.16948 & -3.90 & 0.000 & -89.21578 & -29.02416 \\
\hline lgdpsq & 4.473583 & 1.130267 & 3.96 & $\odot .000$ & 2.231166 & 6.716 \\
\hline educs & - . .0483125 & .0333251 & -1.45 & 0.150 & -.1144285 & .0178036 \\
\hline lpower & 4.747621 & . 8696259 & 5.46 & 0.000 & 3.022308 & 6.472934 \\
\hline$f d i$ & -.5280442 & .2438844 & -2.17 & 0.033 & -1.011904 & - .0441845 \\
\hline trade & - . .0050532 & .0262979 & -0.19 & 0.848 & - . .0572275 & .0471212 \\
\hline capital & .099073 & .0524402 & 1.89 & 0.062 & - . . 0049668 & .2031129 \\
\hline
\end{tabular}


ASARC Working Paper 2016/01

\begin{tabular}{|c|c|c|c|c|c|c|c|}
\hline dum92 & .7827184 & .5210772 & 1.50 & 0.136 & \multicolumn{2}{|l|}{-.251084} & 1.816521 \\
\hline \multicolumn{8}{|l|}{ cid } \\
\hline IND & 19.73534 & 5.100638 & 3.87 & $\odot . \odot \odot \odot$ & \multicolumn{2}{|l|}{9.615818} & 29.85486 \\
\hline LKA & -22.30123 & 5.362687 & -4.16 & $\odot . \odot \odot \odot$ & \multicolumn{2}{|l|}{-32.94065} & -11.66181 \\
\hline PAK & 0 & (omitted) & & & & & \\
\hline _cons & 322.282 & 50.15569 & 6.43 & $\odot .00 \odot$ & \multicolumn{2}{|l|}{222.7746} & 421.7895 \\
\hline \multicolumn{8}{|l|}{ Service } \\
\hline Source & SS & $d f$ & MS & \multicolumn{2}{|c|}{ Number of obs } & $=$ & 115 \\
\hline & ------- & 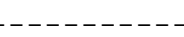 & - - - - - - - - & \multicolumn{2}{|c|}{$F(14,100)$} & $=$ & 39.05 \\
\hline Model & 2944.93879 & 14 & 210.352771 & \multicolumn{2}{|c|}{ Prob $>F$} & $=$ & $\odot .000 \odot$ \\
\hline Residual & 538.719628 & 100 & 5.38719628 & \multicolumn{2}{|c|}{ R-squared } & $=$ & 0.8454 \\
\hline & & & & \multicolumn{2}{|c|}{ Adj R-squared } & $=$ & 0.8237 \\
\hline Total & 3483.65842 & 114 & 30.5584072 & \multicolumn{2}{|c|}{ Root MSE } & $=$ & 2.321 \\
\hline
\end{tabular}

\begin{tabular}{|c|c|c|c|c|c|c|}
\hline service | & Coef. & Std. Err. & $\mathrm{t}$ & $P>|t|$ & {$\left[\begin{array}{ll}95 \% & \text { Conf }\end{array}\right.$} & Interval] \\
\hline lland & -2.019986 & 2.758215 & -0.73 & 0.466 & -7.492207 & 3.452234 \\
\hline lpop & 2.564847 & 3.473228 & 0.74 & 0.462 & -4.325938 & 9.455631 \\
\hline arable & -..1176352 & .1673931 & -0.70 & 0.484 & -.4497384 & .214468 \\
\hline age & - . . 0285935 & .0922711 & -0.31 & $\odot .757$ & -.2116567 & 1544697 \\
\hline $\operatorname{lgdp}$ & 43.06215 & 31.14904 & 1.38 & 0.170 & -18.73666 & 104.861 \\
\hline lgdpsq & -3.004639 & 2.320893 & -1.29 & 0.198 & -7.609224 & 1.599946 \\
\hline educs & .0005509 & .0684298 & 0.01 & 0.994 & -.1352119 & .1363138 \\
\hline lpower & 1.819299 & 1.785692 & 1.02 & 0.311 & -1.723462 & 5.362061 \\
\hline$f d i$ & .0054925 & .5007927 & 0.01 & 0.991 & - .988066 & .999051 \\
\hline trade & -.247066 & .0540002 & -4.58 & $\odot .0 \odot \odot$ & -.3542009 & -.1399311 \\
\hline capital & .4392498 & .1076808 & 4.08 & $\odot .000$ & .2256142 & .6528853 \\
\hline dum92 & 1.870225 & 1.069981 & 1.75 & 0.084 & - . 2525869 & 3.993037 \\
\hline \multicolumn{7}{|l|}{ cid } \\
\hline IND & -9.408826 & 10.47366 & $-0.9 \odot$ & 0.371 & -30.18827 & 11.37062 \\
\hline LKA & .4403177 & 11.01175 & 0.04 & 0.968 & -21.40669 & 22.28732 \\
\hline PAK & $\odot$ & (omitted) & & & & \\
\hline _cons I & -125.555 & 102.9898 & -1.22 & 0.226 & -329.8838 & 78.77388 \\
\hline _cons | & 322.282 & 51.27662 & 6.29 & 0.008 & 159.0969 & 485.467 \\
\hline
\end{tabular}


ASARC Working Paper 2016/01

Table 6: SUR regression with Cross-equation regression

\begin{tabular}{|c|c|c|c|c|c|c|}
\hline & Coef & Std. Err. & z & $P>|z|$ & {$[95 \%$ Conf } & Interval] \\
\hline \multicolumn{7}{|l|}{ agri } \\
\hline lland & .1727678 & 2.583483 & 0.07 & $\odot .947$ & -4.890766 & 5.236302 \\
\hline lpop & 1.950858 & 3.484749 & 0.56 & $\odot .576$ & -4.879125 & 8.78084 \\
\hline arable & -.2330569 & .1516397 & -1.54 & $\odot .124$ & -.5302653 & .0641514 \\
\hline age & .0392116 & .0910558 & 0.43 & $\odot .667$ & -.1392546 & .2176777 \\
\hline lgdp & -40.13721 & 34.578 & -1.16 & 0.246 & -107.9088 & 27.63443 \\
\hline lgdpsq & 3.153104 & 2.55419 & 1.23 & 0.217 & -1.853017 & 8.159224 \\
\hline educs & - . 0073501 & .0075073 & -0.98 & 0.328 & -.0220641 & .007364 \\
\hline lpower & $-8.515107^{*}$ & 1.920897 & -4.43 & $\odot . \odot \odot \odot$ & -12.28 & -4.750217 \\
\hline trade & $.199425^{\star}$ & .0592863 & 3.36 & $\odot . \odot \odot 1$ & .083226 & .315624 \\
\hline capital & $-.6376303^{*}$ & .1138609 & -5.60 & $\odot .0 \odot \odot$ & - . .8607935 & -.414467 \\
\hline dum92 & $.2511995^{\star}$ & .1174119 & 2.14 & 0.032 & .0210765 & .4813225 \\
\hline \multicolumn{7}{|l|}{ cid } \\
\hline IND & 7.043676 & 10.11202 & 0.70 & 0.486 & -12.77552 & 26.86287 \\
\hline LKA & -10.40793 & 10.97092 & -0.95 & 0.343 & -31.91054 & 11.09468 \\
\hline PAK & $-5 . \odot \odot \mathrm{e}-15$ & (omitted) & & & & \\
\hline _cons & 173.954 & 105.6641 & 1.65 & $\odot .100$ & -33.14396 & 381.0519 \\
\hline \multicolumn{7}{|l|}{ manuf } \\
\hline lland & $-2.587093^{*}$ & .7108647 & -3.64 & $\odot .00 \odot$ & -3.980362 & -1.193824 \\
\hline lpop & $-3.604119 *$ & 1.532398 & -2.35 & $\odot .019$ & -6.607565 & -.6006736 \\
\hline age & $.0993158 *$ & .0371074 & 2.68 & $\odot .007$ & .0265867 & .1720449 \\
\hline $\operatorname{lgdp}$ & $-44.08816^{\star}$ & 14.79255 & -2.98 & $\odot .003$ & -73.08102 & -15.0953 \\
\hline lgdpsq & $3.075399 *$ & 1.086186 & 2.83 & 0.005 & .9465134 & 5.204284 \\
\hline educs & - . .0073501 & .0075073 & -0.98 & 0.328 & - . .0220641 & .007364 \\
\hline lpower & $5.891787^{*}$ & .8145995 & 7.23 & 0.000 & 4. 295202 & 7.488373 \\
\hline$f d i$ & -.232241 & .1897768 & -1.22 & 0.221 & -.6041966 & .1397147 \\
\hline trade & .0250555 & .0251978 & 0.99 & 0.320 & -.0243314 & .0744423 \\
\hline capital & .0459727 & .0494358 & $\odot .93$ & 0.352 & - . 0509197 & .1428651 \\
\hline dum92 & $.2511995^{\star}$ & .1174119 & 2.14 & ๑.032 & .0210765 & .4813225 \\
\hline \multicolumn{7}{|l|}{ cid } \\
\hline IND & 10.65767 & 4.252681 & 2.51 & 0.012 & 2.322571 & 18.99277 \\
\hline LKA & -7.17467 & 3.728158 & -1.92 & 0.054 & -14.48173 & .1323851 \\
\hline PAK & $9.96 e-17$ & (omitted) & & & & \\
\hline _cons & 230.8496 & 43.62233 & 5.29 & $\odot . \odot \odot \odot$ & 145.3514 & 316.3478 \\
\hline \multicolumn{7}{|l|}{ service } \\
\hline lland & - .2458308 & 2.415006 & -0.10 & $\odot .919$ & -4.979155 & 4.487493 \\
\hline lpop & .9968217 & 2.96687 & 0.34 & 0.737 & -4.818136 & 6.81178 \\
\hline arable & .0641094 & 1510121 & 0.42 & 0.671 & - . 2318688 & .3600877 \\
\hline age & -.1077193 & .0777434 & -1.39 & $\odot .166$ & -.2600936 & .044655 \\
\hline lgdp & $59.22202 *$ & 28.90537 & 2.05 & 0.040 & 2.568534 & 115.8755 \\
\hline lgdpsq & $-4.300478^{*}$ & 2.142517 & -2.01 & 0.045 & -8.499735 & -.1012224 \\
\hline educs & - .0073501 & $.0 \odot 75073$ & $-\odot .98$ & 0.328 & - . .0220641 & .007364 \\
\hline lpower & $2.784959 *$ & 1.631284 & 1.71 & ๑. 088 & - . 4122979 & 5.982216 \\
\hline$f d i$ & $.4769737^{\star}$ & .2114863 & 2.26 & $\odot .024$ & .0624681 & .8914792 \\
\hline trade & $-.2339569 *$ & .049829 & -4.70 & $\odot .00 \odot$ & - . 3316199 & -.136294 \\
\hline capital & $.3695969 *$ & .0950922 & 3.89 & $\odot .00 \odot$ & .1832196 & .5559741 \\
\hline dum92 & $.2511995^{\star}$ & .1174119 & 2.14 & $\odot . \odot 32$ & .0210765 & .4813225 \\
\hline \multicolumn{7}{|l|}{ cid } \\
\hline IND & -11.0634 & 8.697991 & -1.27 & 0.203 & -28.11115 & 5.984349 \\
\hline LKA & 5.906839 & 9.907324 & 0.60 & 0.551 & -13.51116 & 25.32484 \\
\hline PAK & & (omitted) & & & & \\
\hline
\end{tabular}


ASARC Working Paper 2016/01

$\begin{array}{lllllll}\text { _cons | } & -175.6837 & 89.8231 & -1.96 & 0.050 & -351.7337 & .366358\end{array}$ 
Table 7: Fixed effect models: Country fundamentals only Agriculture sector:

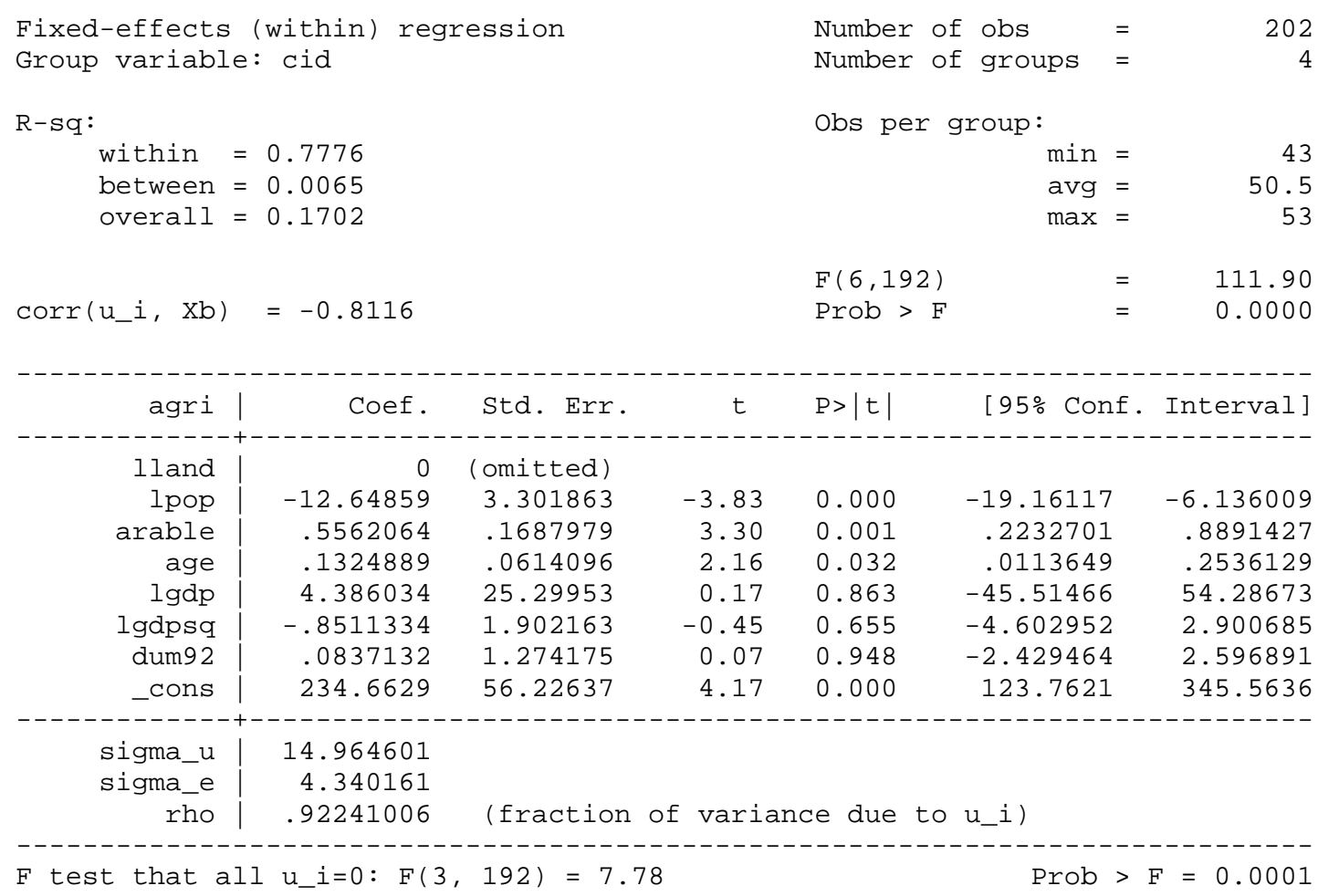

\section{Manufacturing sector}

Fixed-effects (within) regression Group variable: cid

R-sq :

within $=0.2366$

between $=0.4364$

overall $=0.1945$
Number of obs=

Number of groups $=$

202

Obs per group:

$\begin{array}{rrr}\min & = & 43 \\ \operatorname{avg}= & 50.5 \\ \max & = & 53 \\ & = & 9.92 \\ & = & 0.0000\end{array}$

$F(6,192)$

9.92

Prob > F

$\operatorname{corr}\left(u_{-} i, \mathrm{xb}\right)=-\odot .8615$

[95\% Conf. Interval]

\begin{tabular}{|c|c|c|c|c|c|c|}
\hline manuf I & Coef. & Std. Err. & $\mathrm{t}$ & $P>|t|$ & [95\% Conf & Interval] \\
\hline lland & 0 & (omitted) & & & & \\
\hline lpop & 2.702834 & 1.334016 & 2.03 & $\odot .044$ & 0716267 & 5.334042 \\
\hline arable & -.1903421 & .0681976 & -2.79 & 0.006 & -.3248547 & -.0558295 \\
\hline age & -.0432537 & .0248106 & -1.74 & 0.083 & - . . 0921901 & .0056827 \\
\hline lgdp & -13.23041 & 10.22149 & -1.29 & 0.197 & -33.39124 & 6.930427 \\
\hline lgdpsq & 1.025538 & .76851 & 1.33 & 0.184 & -.4902684 & 2.541345 \\
\hline dum92 & -.7493526 & .5147909 & -1.46 & 0.147 & -1.764724 & .266019 \\
\hline _cons & 19.48542 & 22.71653 & 0.86 & 0.392 & -25.32059 & 64.2914 \\
\hline
\end{tabular}




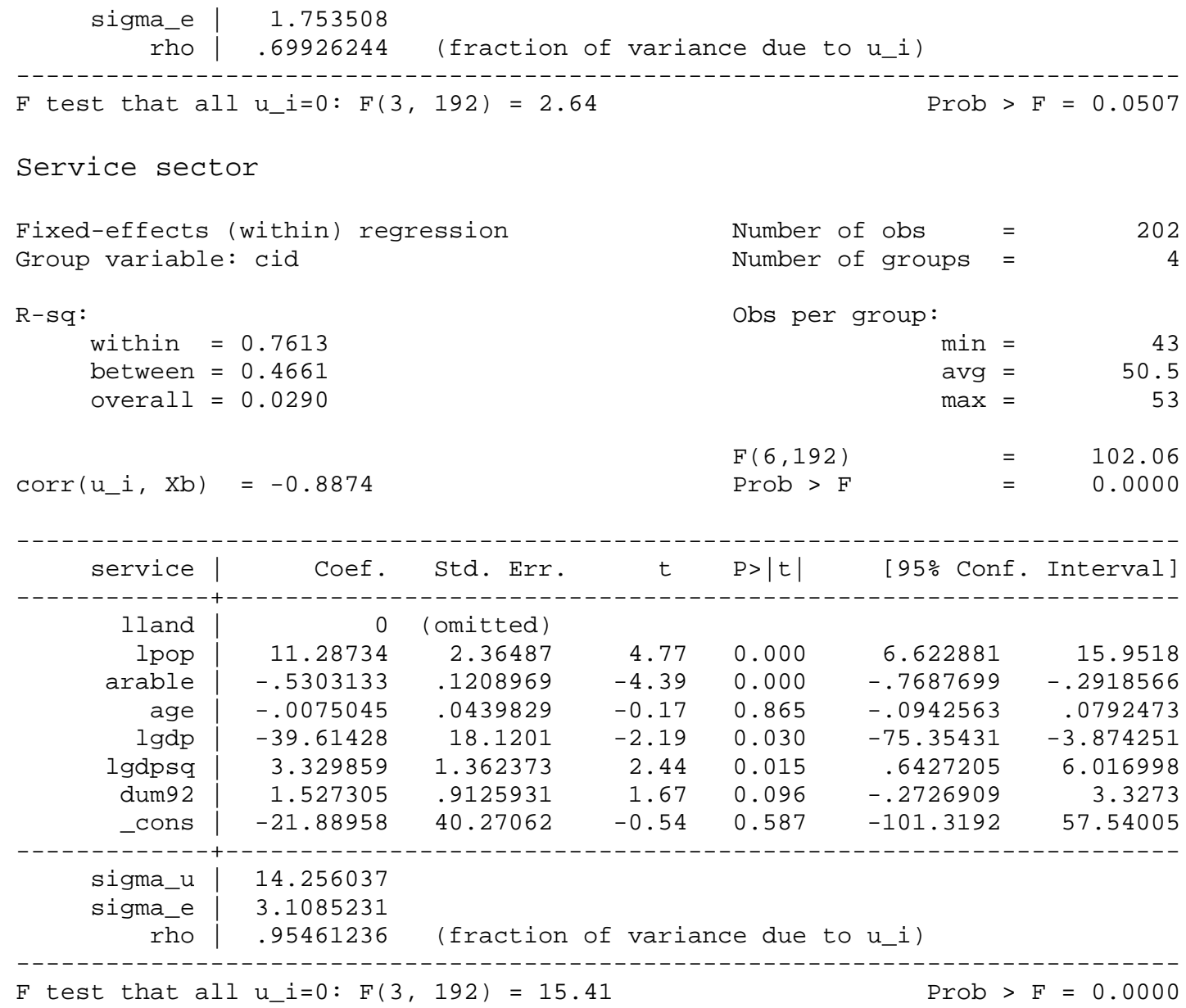




\section{Table 8: Random effect model: Country fundamentals only}

\section{Agriculture sector}

Random-effects GLS regression Group variable: cid

$\mathrm{R}-\mathrm{sq}$ :

within $=0.7561$

between $=0.9873$

overall $=0.7824$

$\operatorname{corr}\left(u_{-} i, x\right)=0$ (assumed)
Number of obs=

Number of groups =

202

obs per group:

$\begin{array}{rrr}\min & = & 43 \\ \operatorname{avg}= & 50.5 \\ \max = & 53 \\ & = & 697.43 \\ & = & 0.0000\end{array}$

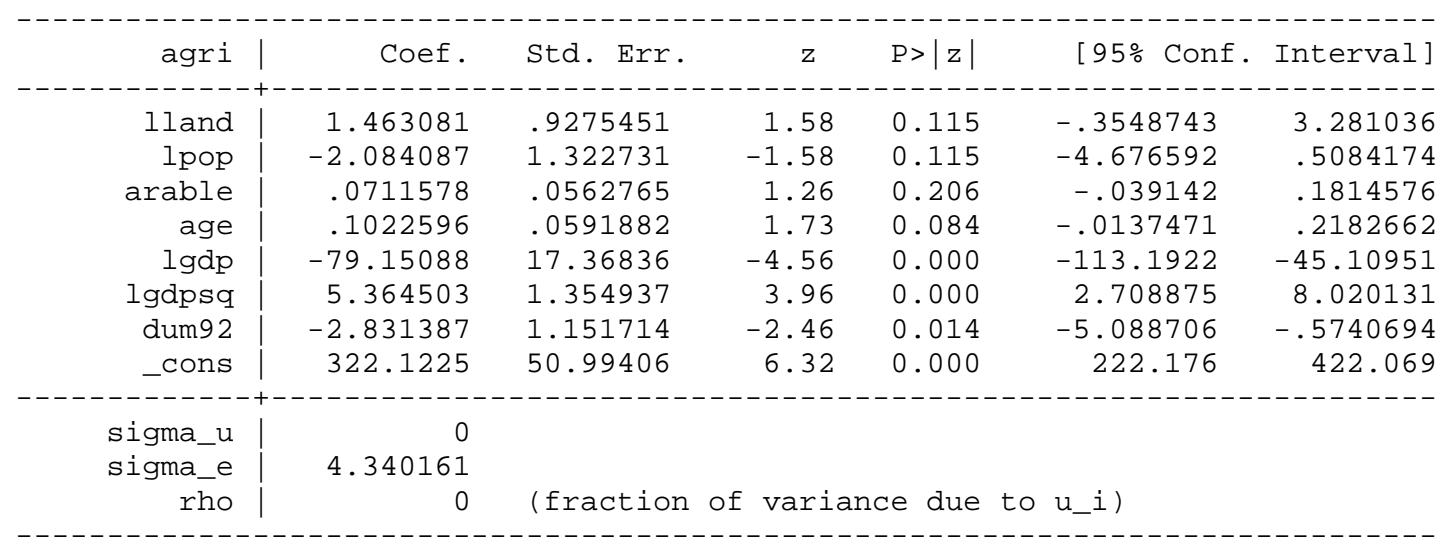

Manufacturing sector

Random-effects GLS regression

Group variable: cid

R-sq :

within $=0.2100$

between $=0.9946$

overall $=0.4280$

$\operatorname{corr}\left(u_{-} i, x\right)=0$ (assumed)
Number of obs=

Number of groups =

202

Obs per group:

$\begin{array}{rlr}\min & = & 43 \\ \mathrm{avg} & = & 50.5 \\ \max & = & 53 \\ \text { Wald chi2(7) } & = & 145.15 \\ \text { Prob }>\text { chi2 } & = & 0.0000\end{array}$

\begin{tabular}{|c|c|c|c|c|}
\hline min & $5 \%$ & median & $95 \%$ & $\max$ \\
\hline$\odot .0 \odot \odot \odot$ & $\odot .0 \odot \odot \odot$ & $\odot . \odot \odot \odot \odot$ & $\odot .000 \odot$ & $\odot .0 \odot \odot \odot$ \\
\hline
\end{tabular}

\begin{tabular}{|c|c|c|c|c|c|c|}
\hline manuf & Coef. & Std. Err. & z & $P>|z|$ & {$[95 \%$ Cont } & Interval] \\
\hline lland & .1502604 & .3632236 & 0.41 & 0.679 & -.5616447 & .8621656 \\
\hline lpop & .2385889 & .517977 & 0.46 & 0.645 & -.7766274 & 1.253805 \\
\hline arable & -.06165 & .0220377 & -2.80 & $\odot .005$ & - . 1048431 & -018457 \\
\hline age & - . .0374915 & .0231779 & -1.62 & $\odot .106$ & - . . .829193 & $.0 \odot 79364$ \\
\hline $\operatorname{lgdp}$ & 7.030908 & 6.801393 & 1.03 & 0.301 & -6.299578 & 20.36139 \\
\hline lgdpsq & -.4908083 & .530589 & -0.93 & $\odot .355$ & -1.530744 & .549127 \\
\hline dum92 & -.0264758 & .4510074 & -0.06 & 0.953 & - .9104341 & .8574825 \\
\hline _cons & -10.06802 & 19.96911 & -0.50 & 0.614 & -49.20675 & 29.07071 \\
\hline
\end{tabular}




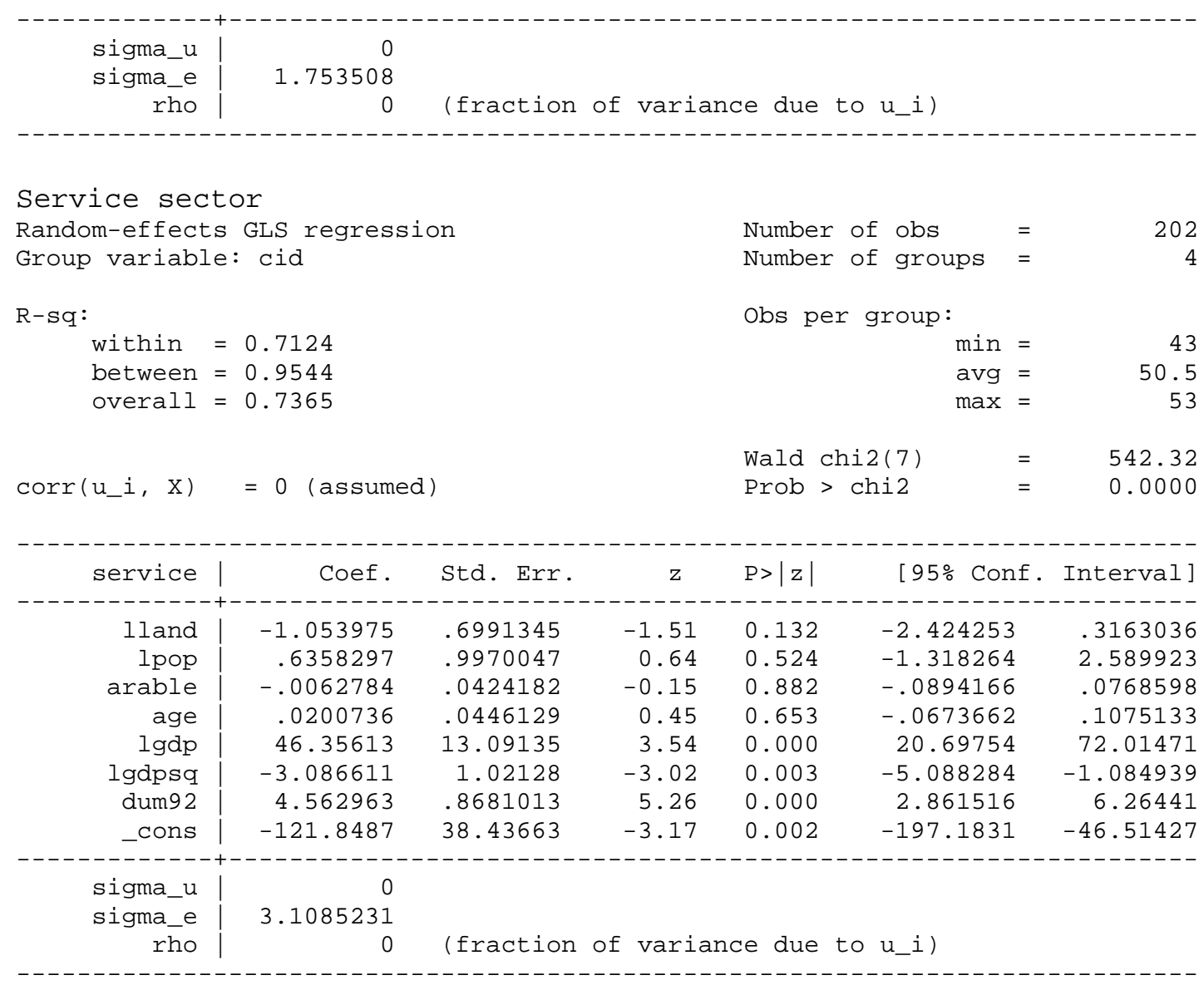


Table 9: Structural transformation extended model: Role of policy variables

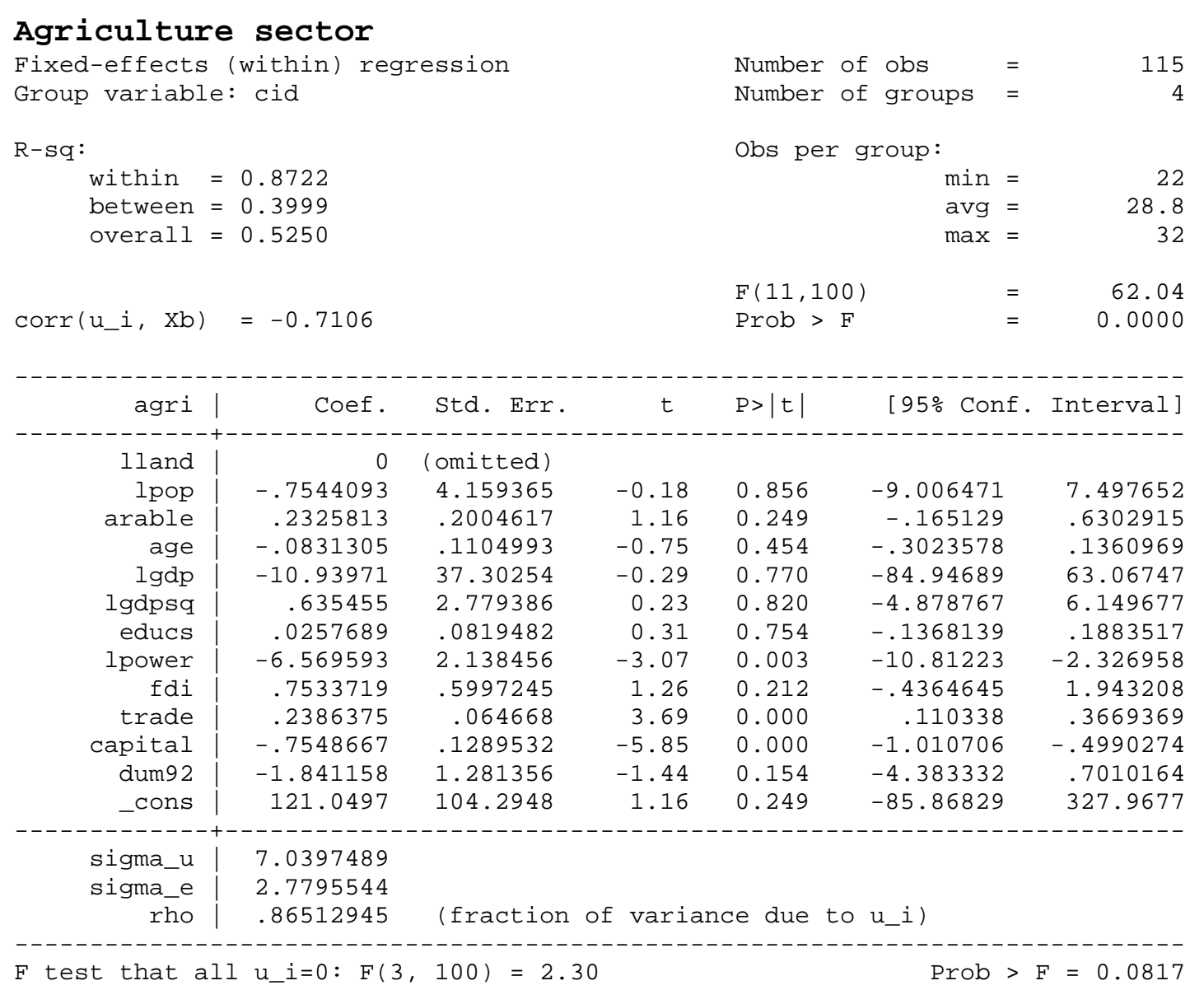

\section{Manufacturing sector}

Fixed-effects (within) regression Group variable: cid

R-sq :

within $=0.5463$

between $=0.6309$

overall $=0.1890$

$\operatorname{corr}\left(u \_i, x b\right)=-0.9853$
Number of obs =

Number of groups =

115

Obs per group:

$\begin{array}{rlr}\min & = & 22 \\ \operatorname{avg}= & 28.8 \\ \max = & 32 \\ & = & 10.95 \\ & = & 0.0000\end{array}$

\begin{tabular}{|c|c|c|c|c|c|c|}
\hline manuf & Coef & Std. Err. & $\mathrm{t}$ & $P>|t|$ & [95\% Conf & Interval] \\
\hline lland & 0 & (omitted) & & & & \\
\hline lpop & -2.224222 & 1.69145 & -1.31 & 0.192 & -5.580011 & 1.131567 \\
\hline arable & - . 3299028 & . $\odot 815199$ & -4.05 & $\odot . \odot \odot \odot$ & -.491636 & -.1681697 \\
\hline age & .1537796 & .0449357 & 3.42 & 0.001 & .0646284 & .2429307 \\
\hline lgdp & -59.11997 & 15.16948 & -3.90 & $\odot .00 \odot$ & -89.21578 & -29.02416 \\
\hline
\end{tabular}


ASARC Working Paper 2016/01

\begin{tabular}{r|rrrrrr} 
lgdpsq & 4.473583 & 1.130267 & 3.96 & 0.000 & 2.231166 & 6.716 \\
educs & -.0483125 & .0333251 & -1.45 & 0.150 & -.1144285 & .0178036 \\
lpower & 4.747621 & .8696259 & 5.46 & 0.000 & 3.022308 & 6.472934 \\
fdi & -.5280442 & .2438844 & -2.17 & 0.033 & -1.011904 & -.0441845 \\
trade & -.0050532 & .0262979 & -0.19 & 0.848 & -.0572275 & .0471212 \\
capital & .099073 & .0524402 & 1.89 & 0.062 & -.0049668 & .2031129 \\
dum92 & .7827184 & .5210772 & 1.50 & 0.136 & -.251084 & 1.816521 \\
cons & 230.5777 & 42.41261 & 5.44 & 0.000 & 146.4323 & 314.7231 \\
sigma_u & 8.1144139 & & & & \\
sigma_e & 1.1303355 & & &
\end{tabular}

$F$ test that all $u_{-} i=0: F(3,100)=9.78$

Prob $>F=0.0000$

\section{Service sector}

Fixed-effects (within) regression Group variable: cid

Number of obs=

115

R-sq:

within $=0.8426$

Number of groups =

between $=0.1533$

Obs per group:

overall $=0.2517$

$\begin{array}{lr}\min = & 22 \\ \operatorname{avg}= & 28.8 \\ \max = & 32\end{array}$

$\operatorname{corr}\left(u_{-} i, X b\right)=-0.7909$

$F(11,100)$

48.68

Prob $>\mathrm{F}$

0.0000

\begin{tabular}{|c|c|c|c|c|c|c|}
\hline service | & Coef. & Std. Err. & $\mathrm{t}$ & $P>|t|$ & {$[95 \%$ Conf } & Interval] \\
\hline lland & 0 & (omitted) & & & & \\
\hline lpop & 2.564847 & 3.473228 & 0.74 & 0.462 & -4.325938 & 9.455631 \\
\hline arable & -.1176352 & .1673931 & -0.70 & $\odot .484$ & -.4497384 & .214468 \\
\hline age & - .0285935 & .0922711 & -0.31 & $\odot .757$ & -.2116567 & .1544697 \\
\hline lgdp & 43.06215 & 31.14904 & 1.38 & 0.170 & -18.73666 & 104.861 \\
\hline lgdpsq & -3.004639 & 2.320893 & -1.29 & $\odot .198$ & -7.609224 & 1.599946 \\
\hline educs & .0005509 & .0684298 & $\odot .01$ & $\odot .994$ & -.1352119 & .1363138 \\
\hline lpower & 1.819299 & 1.785692 & 1.02 & 0.311 & -1.723462 & 5.362061 \\
\hline$f d i$ & .0054925 & .5007927 & 0.01 & 0.991 & -.988066 & .999051 \\
\hline trade & -.247066 & .0540002 & -4.58 & $\odot .00 \odot$ & -.3542009 & -1399311 \\
\hline capital & .4392498 & .1076808 & 4.08 & $\odot .000$ & .2256142 & .6528853 \\
\hline dum92 & 1.870225 & 1.069981 & 1.75 & $\odot .084$ & -.2525869 & 3.993037 \\
\hline _cons & -154.3535 & 87.09014 & -1.77 & 0.079 & -327.1378 & 18.43089 \\
\hline sigma_u & 7.9209003 & & & & & \\
\hline sigma_e & 2.3210335 & & & & & \\
\hline rho & .92092521 & (fraction & vari & ce due & $u_{-i}$ ) & \\
\hline
\end{tabular}

$F$ test that all $u_{-} i=0: F(3,100)=1.90$

Prob $>F=0.1341$ 
ASARC Working Paper 2016/01

Table 10 Extended Random effect model

\section{Agriculture sector}

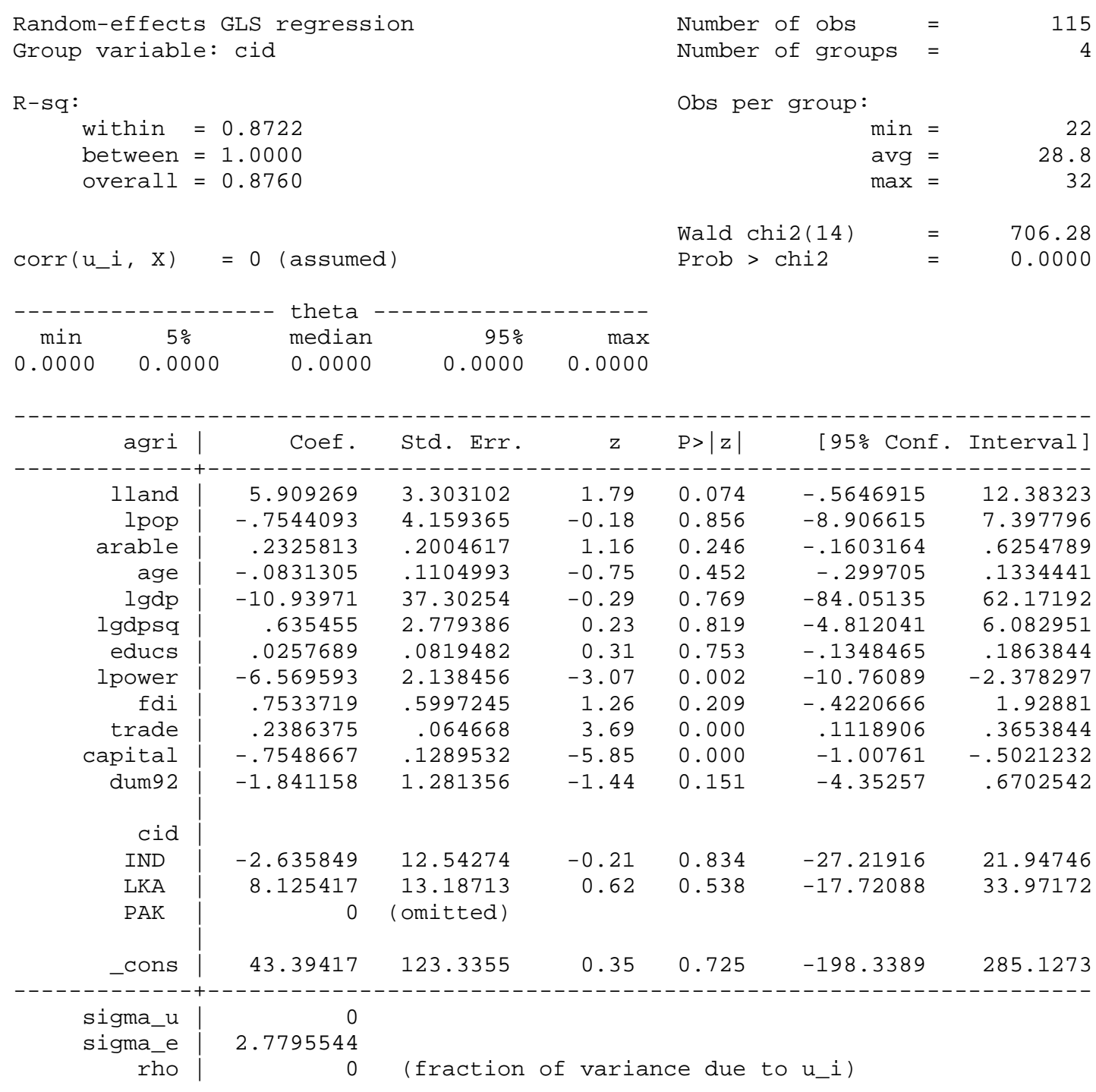

\section{Manufacturing sector}

Random-effects GLS regression Group variable: cid

$\begin{array}{llr}\text { Number of obs } & = \\ \text { Number of groups } & = & 115 \\ \text { Obs per group: } & \\ \min & = & \\ \mathrm{avg} & = & 22 \\ \max & = & 32 \\ & & \\ \text { Wald chi2(14) } & = & 172.37 \\ \text { Prob }>\text { chi2 } & = & 0.0000\end{array}$

$\operatorname{cor} r\left(u_{-} i, x\right)=\odot($ assumed $)$

Prob $>$ chi2 $=0.0000$ 


\begin{tabular}{|c|c|c|c|c|c|c|}
\hline $\begin{array}{c}\min \\
\odot . \odot \odot \odot \odot\end{array}$ & $\begin{array}{l}\text { median } \\
\odot .000 \odot\end{array}$ & $\begin{array}{r}95 \% \\
\odot .0 \odot \odot \odot\end{array}$ & $\begin{array}{r}\max \\
\odot . \odot \odot \odot \odot\end{array}$ & & & \\
\hline manuf | & Coef. & Std. Err. & z & $\mathrm{P}>|\mathrm{z}|$ & [95\% Conf & Interval] \\
\hline lland & -7.147127 & 1.343242 & -5.32 & 0.000 & -9.779832 & -4.514422 \\
\hline lpop & -2.224222 & 1.69145 & -1.31 & 0.189 & -5.539403 & 1.09096 \\
\hline arable & -.3299028 & .0815199 & -4.05 & $\odot .000$ & -.4896789 & -.1701268 \\
\hline age & .1537796 & .0449357 & 3.42 & 0.001 & .0657072 & .2418519 \\
\hline $\operatorname{lgdp}$ & -59.11997 & 15.16948 & -3.90 & $\odot .0 \odot \odot$ & -88.8516 & -29.38834 \\
\hline lgdpsq & 4.473583 & 1.130267 & 3.96 & 0.000 & 2.2583 & 6.688865 \\
\hline educs & -.0483125 & .0333251 & -1.45 & 0.147 & -.1136285 & .0170035 \\
\hline lpower & 4.747621 & .8696259 & 5.46 & $\odot .000$ & 3.043185 & 6.452056 \\
\hline$f d i$ & -.5280442 & .2438844 & -2.17 & 0.030 & -1.006049 & -.0500395 \\
\hline trade & - .0๑50532 & .0262979 & -0.19 & 0.848 & - . .0565962 & .0464898 \\
\hline capital & .099073 & .0524402 & 1.89 & 0.059 & - . .๑๑37078 & .2018539 \\
\hline dum92 & .7827184 & .5210772 & 1.50 & 0.133 & -.2385743 & 1.804011 \\
\hline \multicolumn{7}{|l|}{ cid } \\
\hline IND & 19.73534 & 5.100638 & 3.87 & 0.000 & 9.738272 & 29.73241 \\
\hline LKA & -22.30123 & 5.362687 & -4.16 & $\odot .0 \odot \odot$ & -32.8119 & -11.79055 \\
\hline PAK & $\odot$ & (omitted) & & & & \\
\hline _cons | & 322.282 & 50.15569 & 6.43 & 0.000 & 223.9787 & 420.5854 \\
\hline sigma u & & 0 & & & & \\
\hline sigma_e & 1.1303 & & & & & \\
\hline rho & & (fra & ion of & varia & due & _i) \\
\hline
\end{tabular}

\section{$-\cdots$}

\section{Service sector}

Random-effects GLS regression Group variable: cid

$\mathrm{R}-\mathrm{sq}$ :

within $=0.8426$

between $=1.0000$

overall $=0.8454$
Number of obs $\quad=\quad 115$

Number of groups $=4$

obs per group:

$\begin{array}{lr}\min = & 22 \\ \operatorname{avg}= & 28.8 \\ \max = & 32\end{array}$

Wald $\operatorname{chi2}(14)=546.66$ Prob $>$ chi2 $=0.0000$

\begin{tabular}{|c|c|c|c|c|c|c|}
\hline service & Coef. & Std. Err. & z & $P>|z|$ & {$\left[\begin{array}{ll}95 \% & \text { Conf }\end{array}\right.$} & Interval] \\
\hline lland & -2.019986 & 2.758215 & -0.73 & 0.464 & -7.425989 & 3.386016 \\
\hline lpop & 2.564847 & 3.473228 & 0.74 & 0.460 & -4.242555 & 9.372248 \\
\hline arable & -.1176352 & .1673931 & -0.70 & 0.482 & - . 4457197 & .2104493 \\
\hline age & - . . 0285935 & .0922711 & -0.31 & $\odot .757$ & - . 2094415 & 1522545 \\
\hline lgdp & 43.06215 & 31.14904 & 1.38 & 0.167 & -17.98884 & 104.1131 \\
\hline lgdpsq & -3.004639 & 2.320893 & -1.29 & 0.195 & -7.553505 & 1.544227 \\
\hline educs & $.0 \odot \odot 55 \odot 9$ & .0684298 & $\odot .01$ & $\odot .994$ & - . 1335691 & .1346709 \\
\hline lpower & 1.819299 & 1.785692 & 1.02 & 0.308 & -1.680592 & 5.319191 \\
\hline$f d i$ & .0054925 & .5007927 & 0.01 & $\odot .991$ & -.9760432 & .9870282 \\
\hline trade & -.247066 & .0540002 & -4.58 & $\odot .00 \odot$ & -.3529045 & -.1412275 \\
\hline capital & .4392498 & 1076808 & 4.08 & $\odot .0 \odot \odot$ & .2281993 & .6503002 \\
\hline dum92 & 1.870225 & 1. 069981 & 1.75 & ๑.०८० & - . 2268993 & 3.96735 \\
\hline cid & & & & & & \\
\hline IND & -9.408826 & 10.47366 & -0.90 & 0.369 & -29.93683 & 11.11917 \\
\hline
\end{tabular}


ASARC Working Paper 2016/01

\begin{tabular}{|c|c|c|c|c|c|c|}
\hline LKA & . 4403177 & 11.01175 & 0.04 & 0.968 & -21.14232 & 22.02296 \\
\hline _cons & -125.555 & 102.9898 & -1.22 & 0.223 & -327.4113 & 76.30135 \\
\hline $\begin{array}{r}\text { sigma_u } \\
\text { sigma_e } \\
\text { rho }\end{array}$ & $\begin{array}{r}\odot \\
0.3210335 \\
0\end{array}$ & (fraction & varic & ce due & u_i) & \\
\hline
\end{tabular}


ASARC Working Paper 2016/01

Table 11: Quantile regression (for Agriculture)

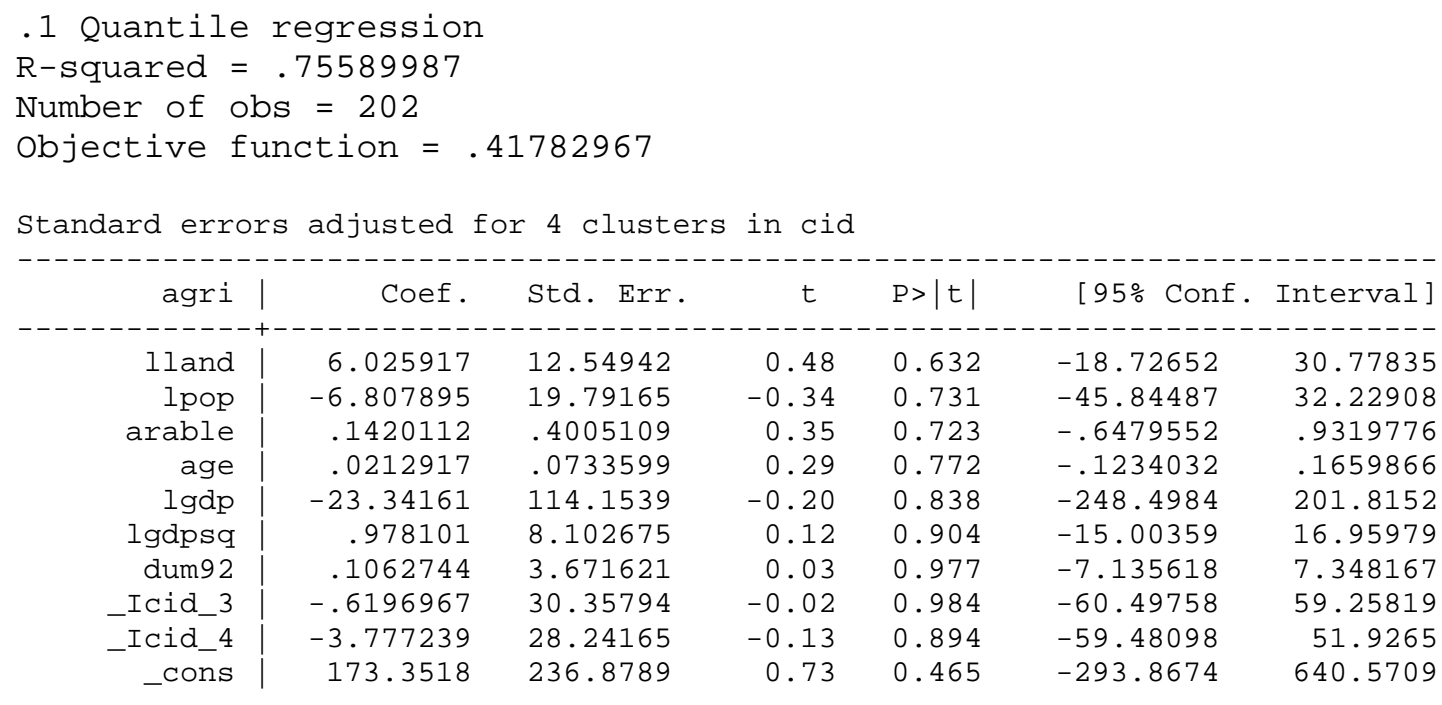

.25 Quantile regression

R-squared $=.76190883$

Number of obs $=202$

Objective function $=.89714797$

Standard errors adjusted for 4 clusters in cid

\begin{tabular}{|c|c|c|c|c|c|c|}
\hline agri | & Coef. & Std. Err. & $\mathrm{t}$ & $P>|t|$ & [95\% Conf & Interval] \\
\hline lland & 6.744334 & 10.65058 & 0.63 & 0.527 & -14.26283 & 27.7514 \\
\hline lpop & -6.923892 & 17.76122 & -0.39 & 0.697 & -41.95605 & 28.1082 \\
\hline arable & .2800104 & .2776827 & 1.01 & 0.315 & -.26769 & .8277109 \\
\hline age & .0088574 & .1207196 & 0.07 & 0.942 & - .2292495 & .2469643 \\
\hline lgdp & -19.06185 & 98.46906 & -0.19 & 0.847 & -213.2819 & 175.1582 \\
\hline lgdpsq & .542049 & 6.888738 & $\odot .08$ & 0.937 & -13.04527 & 14.1293 \\
\hline dum92 & -.0305667 & 2.646877 & -0.01 & 0.991 & -5.251258 & 5.19012 \\
\hline Icid_3 & 7.743882 & 39.32235 & 0.20 & 0.844 & -69.81538 & 85.3031 \\
\hline _Icid_4 & - .9186883 & 30.64249 & -0.03 & $\odot .976$ & -61.35784 & 59.5204 \\
\hline _cons & 149.8168 & 188.3917 & 0.80 & 0.427 & -221.7662 & 521.399 \\
\hline
\end{tabular}

.5 or Median regression

R-squared $=.76458857$

Number of obs $=202$

Objective function $=1.3699545$

Standard errors adjusted for 4 clusters in cid

\begin{tabular}{|c|c|c|c|c|c|c|}
\hline agri | & Coef. & Std. Err. & $\mathrm{t}$ & $P>|t|$ & {$\left[\begin{array}{ll}95 \% & \text { Conf }\end{array}\right.$} & Interval] \\
\hline lland & 5.905965 & 7.108777 & 0.83 & 0.407 & -8.115362 & 19.92729 \\
\hline lpop & -5.307194 & 10.94885 & -0.48 & 0.628 & -26.90267 & 16.28828 \\
\hline arable & .4055244 & .2297789 & 1.76 & 0.079 & - . . 476908 & .8587396 \\
\hline age & -.0334106 & .2464923 & -0.14 & 0.892 & -.5195911 & .4527699 \\
\hline $\operatorname{lgdp}$ & -30.2418 & 278.9408 & -0.11 & 0.914 & -580.4236 & 519.94 \\
\hline
\end{tabular}


ASARC Working Paper 2016/01

\begin{tabular}{r|rrrrrr} 
lgdpsq & 1.365709 & 22.74852 & 0.06 & 0.952 & -43.5034 & 46.23482 \\
dum92 & -.0933303 & 1.435009 & -0.07 & 0.948 & -2.923736 & 2.737076 \\
Icid_3 & 18.40118 & 22.63244 & 0.81 & 0.417 & -26.23896 & 63.04132 \\
_Icid_4 & 4.423845 & 17.53445 & 0.25 & 0.801 & -30.16104 & 39.00873 \\
_cons & 163.416 & 810.3996 & 0.20 & 0.840 & -1435.013 & 1761.845
\end{tabular}

\section{.75 Quantile regression}

$\mathrm{R}$-squared $=.68862521$

Number of obs $=202$

Objective function $=1.2833906$

\begin{tabular}{|c|c|c|c|c|c|c|}
\hline agri & Coef. & Std. Err. & $\mathrm{t}$ & $P>|t|$ & [95\% Conf & Interval] \\
\hline lland & 4.365565 & 9.131733 & 0.48 & 0.633 & -13.64583 & 22.37696 \\
\hline lpop & -2.266261 & 14.33167 & -0.16 & 0.875 & -30.53399 & 26.00147 \\
\hline arable & 1.012394 & .3274361 & 3.09 & 0.002 & .3665603 & 1.658228 \\
\hline age & .1440377 & .2618373 & 0.55 & 0.583 & - . 3724091 & .6604846 \\
\hline lgdp & -113.9742 & 104.8523 & -1.09 & 0.278 & -320.7845 & 92.83616 \\
\hline lgdpsq & 8.304377 & 7.878269 & 1.05 & 0.293 & -7.234693 & 23.84345 \\
\hline dum92 & -1.357392 & 2.480159 & -0.55 & 0.585 & -6.24925 & 3.534466 \\
\hline -Icid_3 & 50.1936 & 31.7721 & 1.58 & 0.116 & -12.47358 & 112.8608 \\
\hline _Icid_4 & 15.28253 & 24.6089 & 0.62 & 0.535 & -33.25596 & 63.82103 \\
\hline cons & 332.1833 & 264.3258 & 1.26 & 0.210 & -189.1719 & 853.5385 \\
\hline
\end{tabular}

.9 Quantile regression

$\mathrm{R}$-squared $=.56555208$

Number of obs $=202$

Objective function $=.64608283$

Standard errors adjusted for 4 clusters in cid

\begin{tabular}{|c|c|c|c|c|c|c|}
\hline agri & Coef. & Std. Err. & $\mathrm{t}$ & $P>|t|$ & [95\% Conf. & Interval] \\
\hline lland & -.1605114 & 3.253766 & -0.05 & 0.961 & -6.578228 & 6.257205 \\
\hline lpop & 5.806666 & 6.108648 & 0.95 & 0.343 & -6.24201 & 17.85534 \\
\hline arable & 1.499243 & .9790836 & 1.53 & 0.127 & -.4318976 & 3.430385 \\
\hline age & .2182591 & .5676169 & 0.38 & 0.701 & -.9013064 & 1.337825 \\
\hline lgdp & -199.8664 & 76.81825 & -2.60 & 0.010 & -351.3825 & -48.35039 \\
\hline lgdpsq & 14.73628 & 5.679058 & 2.59 & 0.010 & 3.534923 & 25.93763 \\
\hline dum92 & -1.144978 & 2.55572 & -0.45 & 0.655 & -6.185872 & 3.895916 \\
\hline Icid_3 & 87.66523 & 53.10208 & 1.65 & 0.100 & -17.07313 & 192.4036 \\
\hline Icid_4 & 34.72099 & 27.80061 & 1.25 & 0.213 & -20.11283 & 89.55481 \\
\hline _cons & 486.7768 & 197.8019 & 2.46 & 0.015 & 96.63311 & 876.9205 \\
\hline
\end{tabular}

Parente-Santos Silva test for intra-cluster correlation Ho: No intra-cluster correlation

$\begin{array}{ccr}T & = & -1.331 \\ P>|T| & = & 0.183\end{array}$ 
ASARC Working Paper 2016/01

Table 12: Quantile regression (for manufacturing).

.1 Quantile regression

$\mathrm{R}$-squared $=.25685134$

Number of obs $=202$

Objective function $=.29942622$

Standard errors adjusted for 4 clusters in cid

\begin{tabular}{|c|c|c|c|c|c|c|}
\hline manuf & Coef. & Std. Err. & $\mathrm{t}$ & $P>|t|$ & {$\left[\begin{array}{ll}95 \% & \text { Conf }\end{array}\right.$} & Interval] \\
\hline lland & -1.168531 & 9.924291 & -0.12 & $\odot .906$ & -20.74317 & 18.40611 \\
\hline lpop & .152779 & 15.79369 & 0.01 & $\odot .992$ & -30.99865 & 31.30421 \\
\hline arable & - . 3951308 & .0466283 & -8.47 & $\odot .000$ & - . 4871003 & - . 3031614 \\
\hline age & - . 0545451 & .0517142 & -1.05 & 0.293 & -.1565461 & .0474558 \\
\hline $\operatorname{lgdp}$ & 18.81033 & 133.7647 & 0.14 & 0.888 & -245.0266 & 282.6473 \\
\hline lgdpsq & -1.536015 & 9.95085 & -0.15 & $\odot .877$ & -21.16304 & 18.09101 \\
\hline dum92 & .5402922 & .863595 & 0.63 & $\odot .532$ & -1.16306 & 2.243644 \\
\hline Icid_3 & -18.99373 & 30.00376 & -0.63 & $\odot .527$ & -78.17303 & 40.18557 \\
\hline Icid_4 & -7.176829 & 19.23497 & -0.37 & 0.709 & -45.11582 & 30.76216 \\
\hline _cons & -4.208472 & 273.3959 & -0.02 & 0.988 & -543.4535 & 535.036 \\
\hline
\end{tabular}

.25 Quantile regression

$\mathrm{R}$-squared $=.3262405$

Number of obs $=202$

Objective function $=.52771589$

Standard errors adjusted for 4 clusters in cid

manuf |
lland |

Median regression

$\mathrm{R}$-squared $=.40582817$

Number of obs $=202$

Objective function $=.58728595$

Standard errors adjusted for 4 clusters in cid

\begin{tabular}{|c|c|c|c|c|c|c|}
\hline manuf & Coef. & Std. Err. & $t$ & $P>|t|$ & [95\% Conf. & Interval] \\
\hline \multicolumn{7}{|c|}{ 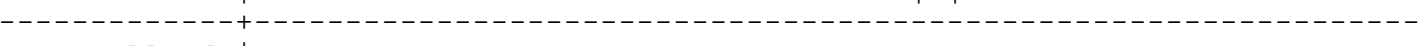 } \\
\hline lland & -2.852337 & 4.396666 & -0.65 & 0.517 & -11.52431 & 5.819632 \\
\hline lpop & 3.194549 & 7.059514 & 0.45 & 0.651 & -10.72961 & 17.118 \\
\hline arable & -.270242 & .0915574 & -2.95 & 0.004 & -.4508295 & -.08965 \\
\hline
\end{tabular}


ASARC Working Paper 2016/01

\begin{tabular}{r|rrrrrr} 
age & -.009187 & .0680183 & -0.14 & 0.893 & -.143346 & .124972 \\
lgdp & -28.29474 & 36.91982 & -0.77 & 0.444 & -101.1153 & 44.52579 \\
lgdpsq & 2.279548 & 2.573322 & 0.89 & 0.377 & -2.796064 & 7.355159 \\
dum92 & -1.20546 & .6599022 & -1.83 & 0.069 & -2.507049 & .0961287 \\
Icid_3 & -8.322717 & 14.75104 & -0.56 & 0.573 & -37.41761 & 20.77218 \\
Icid_4 & .0094266 & 11.95787 & 0.00 & 0.999 & -23.57624 & 23.59509 \\
_cons & 95.5441 & 66.99955 & 1.43 & 0.155 & -36.60558 & 227.6938 \\
\hline
\end{tabular}

.75 Quantile regression
R-squared $=.43336599$

Number of obs $=202$

Objective function $=.43210103$

Standard errors adjusted for 4 clusters in cid

\begin{tabular}{|c|c|c|c|c|c|c|}
\hline manuf & Coef. & Std. Err. & $\mathrm{t}$ & $P>|t|$ & [95\% Conf & Interval] \\
\hline lland & -2.035974 & 3.499847 & -0.58 & 0.561 & -8.93906 & 4.867112 \\
\hline lpop & 2. 318803 & 5.869162 & 0.40 & 0.693 & -9.257511 & 13.89512 \\
\hline arable & - . 218818 & .1676865 & -1.30 & 0.193 & -.5495623 & .1119264 \\
\hline age & - . .๑46107 & .0750171 & $-\odot .06$ & 0.951 & -.1525741 & .1433527 \\
\hline lgdp & -14.77998 & 23.65768 & -0.62 & 0.533 & -61.4423 & 31.88234 \\
\hline $\operatorname{lgdpsq}$ & 1.229976 & 1.582619 & 0.78 & 0.438 & -1.891576 & 4.351527 \\
\hline dum92 & -.8745906 & .7596256 & -1.15 & 0.251 & -2.372873 & .6236921 \\
\hline Icid_3 & -5.855927 & 17.35959 & -0.34 & 0.736 & -40.09592 & 28.38407 \\
\hline Icid_4 & -.3768884 & 12.434 & -0.03 & 0.976 & -24.90166 & 24.14789 \\
\hline _cons & 55.56805 & 34.43232 & 1.61 & 0.108 & -12.34615 & 123.482 \\
\hline
\end{tabular}

.9 Quantile regression

R-squared $=.37350765$

Number of obs $=202$

Objective function $=.22910984$

Standard errors adjusted for 4 clusters in cid

\begin{tabular}{|c|c|c|c|c|c|c|}
\hline manuf & Coef. & Std. Err. & $\mathrm{t}$ & $P>|t|$ & [95\% Conf & Interval] \\
\hline 11 and & 8657852 & 9459393 & -902 & A 361 & -2731473 & 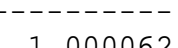 \\
\hline $\begin{array}{r}\perp \text { and } \\
\text { lpop }\end{array}$ & $\begin{array}{r}-.865 / 053 \\
1.39237\end{array}$ & $\begin{array}{l}.9459393 \\
1.658143\end{array}$ & $\begin{array}{r}-0.92 \\
0.84\end{array}$ & $\begin{array}{l}0.361 \\
0.402\end{array}$ & -1.878146 & 4.662885 \\
\hline arable & -.0710407 & .0784874 & -0.91 & 0.367 & -.2258489 & .0837675 \\
\hline age & -.0340966 & .0221036 & -1.54 & 0.125 & -.0776937 & .0095005 \\
\hline lgdp & 9.848798 & 8.052912 & 1.22 & 0.223 & -6.034737 & 25.73233 \\
\hline $\operatorname{lgdpsq}$ & -.7317742 & .5742125 & -1.27 & 0.204 & -1.864349 & .4008006 \\
\hline dum92 & -.638097 & .3014832 & -2.12 & $\odot .036$ & -1.232741 & -.0434526 \\
\hline Icid_3 & 2.313061 & 5.738862 & 0.40 & 0.687 & -9.006251 & 13.63237 \\
\hline Icid_4 & 1.298766 & 3.884501 & 0.33 & 0.738 & -6.36301 & 8.960542 \\
\hline _cons & -25.14824 & 16.91196 & -1.49 & 0.139 & -58.50532 & 8.208841 \\
\hline
\end{tabular}




\section{Table 13: Quantile regression (services sector)}

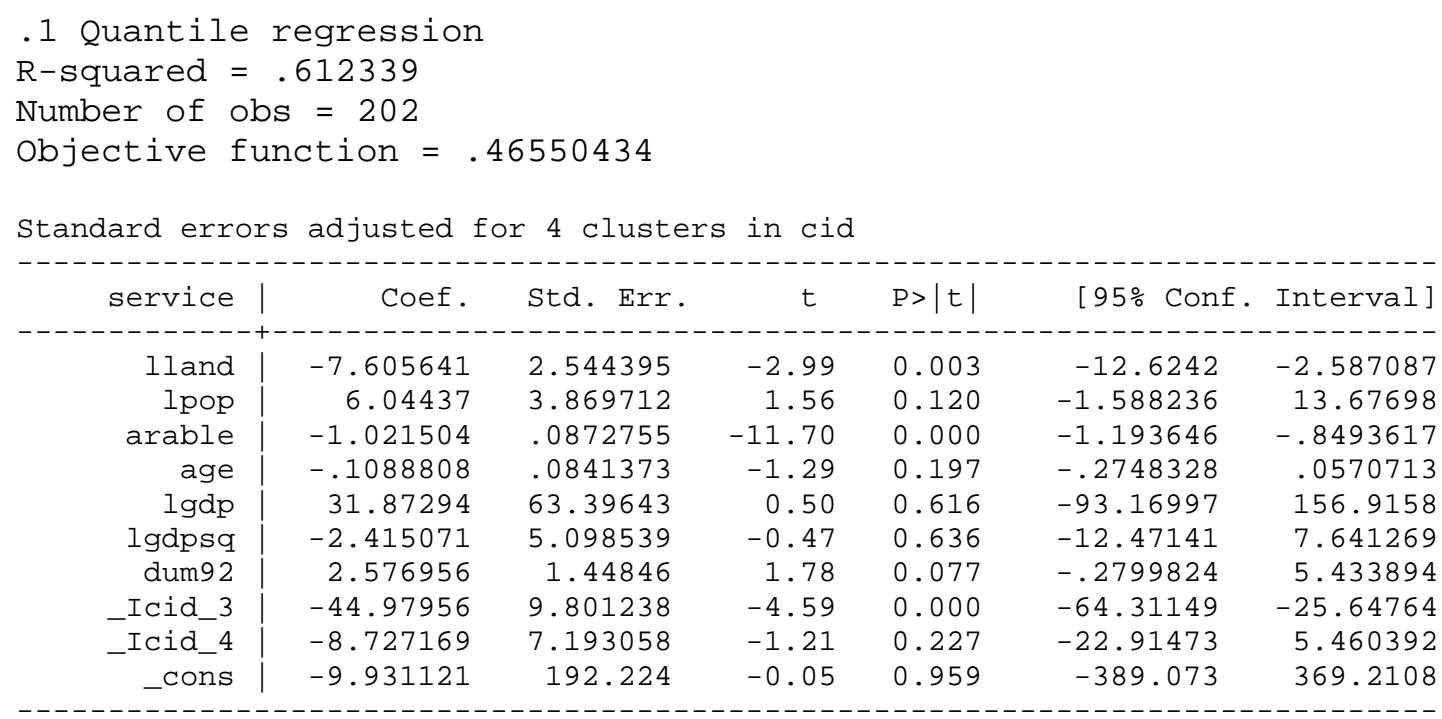

.25 Quantile regression

R-squared $=.74168435$

Number of obs $=202$

Objective function $=.89892714$

Standard errors adjusted for 4 clusters in cid

\begin{tabular}{|c|c|c|c|c|c|c|}
\hline service & Coef. & Std. Err. & $\mathrm{t}$ & $P>|t|$ & [95\% Conf & Interval] \\
\hline lland & -6.303562 & 4.096537 & -1.54 & 0.126 & -14.38356 & 1.776432 \\
\hline lpop & 6.486121 & 6.267548 & 1.03 & 0.302 & -5.875969 & 18.84821 \\
\hline arable & -.245578 & .1893137 & -1.30 & 0.196 & - . 6189797 & .1278237 \\
\hline age & - .0939963 & .1944364 & -0.48 & 0.629 & -.4775019 & .2895093 \\
\hline $\operatorname{lgdp}$ & 2.124242 & $9 \odot .15565$ & 0.02 & $\odot .981$ & -175.6985 & 179.9469 \\
\hline lgdpsq & .2429127 & 7.325281 & 0.03 & 0.974 & -14.20545 & 14.69127 \\
\hline dum92 & 1.074998 & 1.031605 & 1.04 & 0.299 & -.959736 & 3.109733 \\
\hline Icid_3 & -8.947933 & 14.18188 & -0.63 & 0.529 & -36.92023 & 19.02436 \\
\hline Icid_4 & 4.756574 & 11.00347 & 0.43 & 0.666 & -16.94664 & 26.45979 \\
\hline _cons & 2.724578 & 267.4369 & 0.01 & 0.992 & -524.767 & 530.2162 \\
\hline
\end{tabular}

Median regression

R-squared $=.71401113$

Number of obs $=202$

Objective function $=1.0595148$

Standard errors adjusted for 4 clusters in cid

\begin{tabular}{|c|c|c|c|c|c|c|}
\hline service & Coef & Std. Err. & $\mathrm{t}$ & $P>|t|$ & [95\% Conf & Interval] \\
\hline lland & -7.175162 & 3.173641 & -2.26 & 0.025 & -13.43484 & -.91 \\
\hline lpop & 7.370269 & 4.098625 & 1.80 & 0.074 & -.7138445 & 15.45438 \\
\hline arable & $-.204 \odot 444$ & .2824643 & -0.72 & 0.471 & -.7611759 & .3530872 \\
\hline age & .0044135 & .1435602 & 0.03 & 0.976 & -.2787442 & .2875712 \\
\hline lgdp & -25.81364 & 43.76912 & -0.59 & 0.556 & -112.1437 & 60.51642 \\
\hline
\end{tabular}


ASARC Working Paper 2016/01

\begin{tabular}{|c|c|c|c|c|c|c|}
\hline lgdpsq & 2.573284 & 3.334865 & 0.77 & 0.441 & -4.004391 & 9.150959 \\
\hline dum92 & .7817091 & 1.071299 & 0.73 & 0.466 & -1.331317 & 2.894735 \\
\hline Icid_3 & -6.677984 & 11.80018 & -0.57 & 0.572 & -29.95261 & 16.59664 \\
\hline Icid_4 & 5.157844 & 6.849342 & 0.75 & 0.452 & -8.351775 & 18.66746 \\
\hline _cons & 72.63889 & 129.9758 & 0.56 & 0.577 & -183.7249 & 329.0027 \\
\hline
\end{tabular}

.75 Quantile regression

$\mathrm{R}$-squared $=.74452678$

Number of obs $=202$

Objective function $=.74366382$

Standard errors adjusted for 4 clusters in cid

\begin{tabular}{|c|c|c|c|c|c|c|}
\hline service & Coef. & Std. Err. & $\mathrm{t}$ & $P>|t|$ & [95\% Conf & Interval] \\
\hline lland & -5.827812 & 1.839412 & -3.17 & $\odot .0 \odot 2$ & -9.455861 & -2.199762 \\
\hline Ірор & 5.49529 & 3.49408 & 1.57 & 0.117 & -1.396421 & 12.387 \\
\hline arable & -.2126158 & .1092559 & -1.95 & 0.053 & -.4281118 & .0028801 \\
\hline age & .0538823 & 1209315 & 0.45 & 0.656 & -.1846425 & 2924071 \\
\hline lgdp & 13.242 & 32.32406 & 0.41 & 0.683 & -50.51386 & 76.99786 \\
\hline lgdpsq & -.4922988 & 2.430033 & -0.20 & 0.840 & -5.285286 & 4.300689 \\
\hline dum92 & 2.001757 & 2.806009 & 0.71 & 0.476 & -3.532805 & 7.536319 \\
\hline Icid_3 & -5.166455 & 10.67959 & $-\odot .48$ & 0.629 & -26.23085 & 15.89794 \\
\hline _Icid_4 & 2.25563 & 6.467373 & 0.35 & 0.728 & -10.50059 & 15.01185 \\
\hline _cons & -34.96516 & 77.11534 & -0.45 & 0.651 & -187.0672 & 117.1369 \\
\hline
\end{tabular}

.9 Quantile regression

R-squared $=.72429222$

Number of obs $=202$

Objective function $=.3682329$

Standard errors adjusted for 4 clusters in cid

\begin{tabular}{|c|c|c|c|c|c|c|}
\hline service & Coef. & Std. Err. & $\mathrm{t}$ & $P>|t|$ & {$[95 \%$ Conf } & Interval] \\
\hline 11 and & -501825 & 1548751 & -324 & ค คค1 & -8 - $9730 ค 1$ & $-1 \quad 963499$ \\
\hline lpop & 4.584432 & 2. 237721 & 2.05 & 0.042 & .1707593 & 8.998105 \\
\hline arable & -.2114507 & .1246502 & -1.70 & 0.091 & - .4573103 & 0344089 \\
\hline age & .1207066 & .0944724 & 1.28 & 0.203 & - . .0656305 & .3070437 \\
\hline lgdp & $23.30 \odot 45$ & 27.83825 & $\odot .84$ & 0.404 & -31.60761 & 78.2085 \\
\hline lgdpsq & -1.256011 & 2.133719 & $-\odot .59$ & $\odot .557$ & -5.46455 & 2.952529 \\
\hline dum92 & 2.994259 & 1.657387 & 1.81 & 0.072 & - . 2747649 & 6.263283 \\
\hline Icid_3 & -5.001783 & 4.896227 & -1.02 & 0.308 & -14.65908 & 4.655518 \\
\hline Icid_4 & .34631 & 2.855699 & 0.12 & 0.904 & -5.286261 & 5.978881 \\
\hline _cons & -65.3215 & 74.72835 & -0.87 & 0.383 & -212.7154 & 82.0724 \\
\hline
\end{tabular}


Table 14: Quantile regressions for model with policy variables (agriculture)

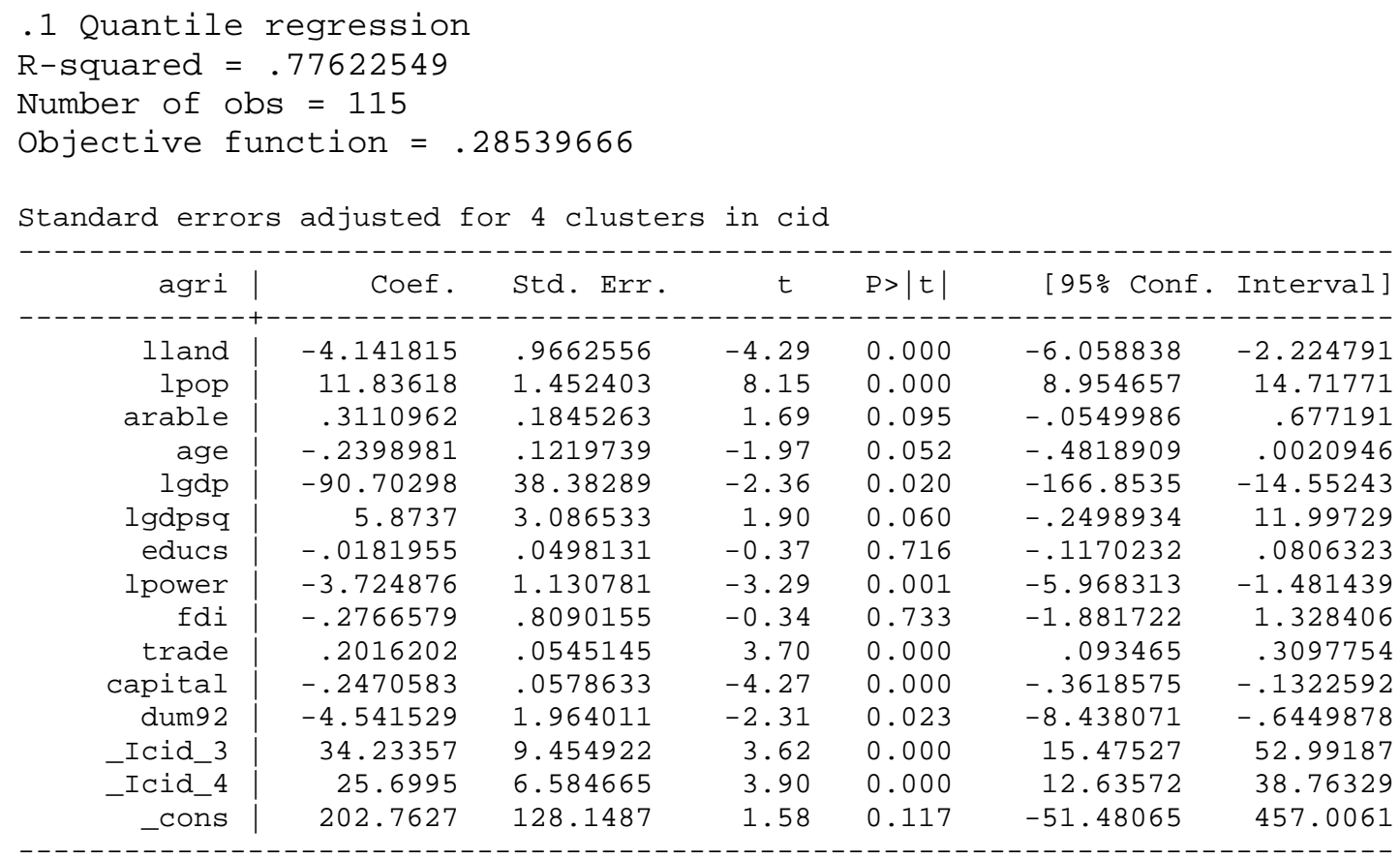

.25 Quantile regression

$\mathrm{R}$-squared $=.81659369$

Number of obs $=115$

Objective function $=.59513395$

Standard errors adjusted for 4 clusters in cid

\begin{tabular}{|c|c|c|c|c|c|c|}
\hline agri | & Coef. & Std. Err. & $\mathrm{t}$ & $P>|t|$ & {$\left[\begin{array}{ll}95 \% & \text { Conf }\end{array}\right.$} & Interval] \\
\hline lland & -1.421887 & 1.369891 & -1.04 & 0,302 & $-4,139713$ & 1.295938 \\
\hline lpop & 8.661935 & 1.708951 & 5.07 & 0.000 & 5.271425 & 12.05245 \\
\hline arable & .4112284 & .1932703 & 2.13 & 0.036 & .0277856 & .7946712 \\
\hline age & - . 2471085 & .0893539 & -2.77 & $\odot .0 \odot 7$ & -.424384 & - .0698329 \\
\hline $\operatorname{lgdp}$ & $-71.632 \odot 4$ & 23.05246 & -3.11 & $\odot .0 \odot 2$ & -117.3675 & -25.89661 \\
\hline lgdpsq & 4.392387 & 1.733067 & 2.53 & 0.013 & .9540314 & 7.830742 \\
\hline educs & .0627616 & .0262715 & 2.39 & 0.019 & .0106397 & .1148836 \\
\hline lpower & -3.98784 & 2.161949 & -1.84 & 0.068 & -8.277084 & .3014045 \\
\hline$f d i$ & .5522082 & .182261 & 3.03 & 0.003 & .1906075 & .9138089 \\
\hline trade & .2749491 & .0386303 & 7.12 & $\odot .0 \odot \odot$ & .1983077 & .3515905 \\
\hline capital & -.4863677 & .0470233 & -10.34 & $\odot .0 \odot \odot$ & -.5796606 & -.3930749 \\
\hline dum92 & -5.05762 & .8524061 & -5.93 & 0.000 & -6.748769 & -3.366471 \\
\hline _Icid_3 & 30.28629 & 7.847135 & 3.86 & 0.000 & 14.7178 & 45.85479 \\
\hline _Icid_4 & 22.74133 & 4.575932 & 4.97 & $\odot .000$ & 13.66281 & 31.81985 \\
\hline _cons & 164.4334 & 64.14085 & 2.56 & 0.012 & 37.17979 & 291.687 \\
\hline
\end{tabular}




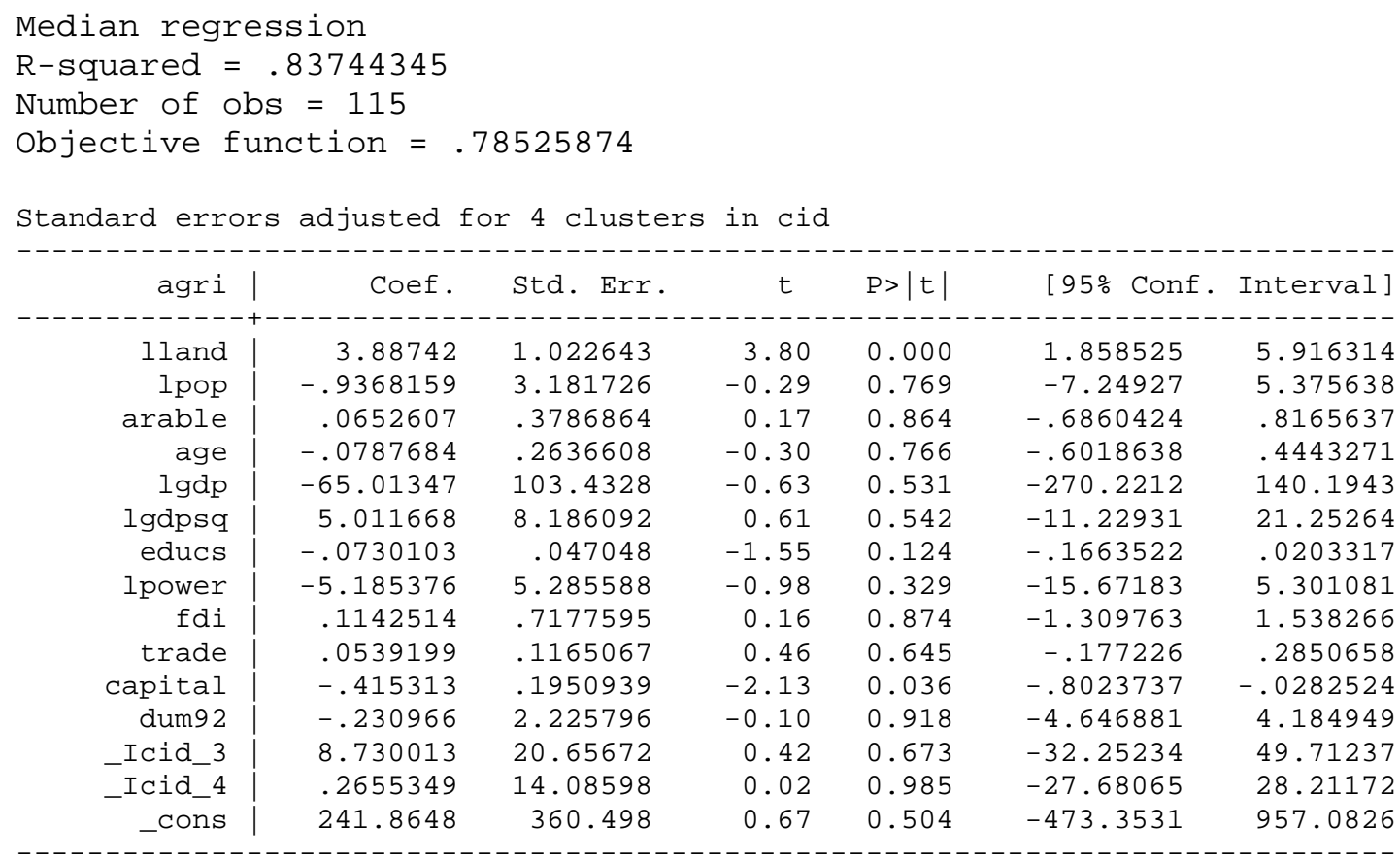

.75 Quantile regression

$\mathrm{R}$-squared $=.83364746$

Number of obs $=115$

Objective function $=.6209392$

Standard errors adjusted for 4 clusters in cid

\begin{tabular}{|c|c|c|c|c|c|c|}
\hline agri | & Coef. & Std. Err. & $\mathrm{t}$ & $P>|t|$ & [95\% Conf & Interval] \\
\hline lland & 1.434363 & 3.189281 & 0.45 & 0.654 & -4.893079 & 7.76180 \\
\hline lpop & 3.069457 & 5.797481 & 0.53 & $\odot .598$ & -8.432581 & 14.571 \\
\hline arable & -.5477146 & .2544555 & -2.15 & $\odot .034$ & -1.052547 & -.042882 \\
\hline age & .2063235 & .1857237 & 1.11 & 0.269 & -.1621471 & .574794 \\
\hline $\operatorname{lgd} p$ & -12.46 & 124.5635 & -0.10 & 0.921 & -259.5904 & 234.6704 \\
\hline lgdpsq & 1.673307 & 9.601186 & 0.17 & 0.862 & -17.37517 & 20.72179 \\
\hline educs & - .0636468 & .0972144 & -0.65 & 0.514 & -.2565174 & .1292237 \\
\hline lpower & -11.2084 & 5.718581 & -1.96 & $\odot .053$ & -22.5539 & .1371014 \\
\hline$f d i$ & .3068639 & .3726872 & 0.82 & 0.412 & -.432537 & 1.04626 \\
\hline trade & .0730374 & .108609 & 0.67 & 0.503 & -.1424398 & .2885145 \\
\hline capital & -.6373978 & .2457385 & -2.59 & 0.011 & -1.124936 & - .1498596 \\
\hline dum92 & .9338415 & 1.285608 & 0.73 & 0.469 & -1.616769 & 3.484452 \\
\hline _Icid_3 & -17.00745 & 19.95498 & -0.85 & 0.396 & -56.59757 & 22.58266 \\
\hline _Icid_4 & -12.05625 & 15.35997 & -0.78 & 0.434 & -42.53 & 18.41749 \\
\hline _cons & 52.31541 & 432.6863 & 0.12 & 0.904 & -806.1218 & 910.752 \\
\hline
\end{tabular}

.9 Quantile regression

R-squared $=.82547993$

Number of obs $=115$

Objective function $=.30793009$

Standard errors adjusted for 4 clusters in cid 
ASARC Working Paper 2016/01

\begin{tabular}{|c|c|c|c|c|c|c|}
\hline agri & Coef. & Std. Err & $\mathrm{t}$ & $P>|t|$ & {$[95 \%$} & \\
\hline lland & 5.103151 & 1.578251 & 3.23 & $\odot .0 \odot 2$ & 1.971945 & 8.234356 \\
\hline lpop & -.3540085 & 1.155137 & -0.31 & 0.760 & -2.645767 & 1.93775 \\
\hline arable & - .0844894 & .5584849 & -0.15 & 0.880 & -1.192507 & 1.023529 \\
\hline age & .1108671 & .1257561 & 0.88 & 0.380 & -.1386295 & .3603637 \\
\hline $\operatorname{lgdp}$ & 45.79153 & 79.49341 & $\odot .58$ & 0.566 & -111.9211 & 203.5042 \\
\hline lgdpsq & -2.44253 & 5.93476 & -0.41 & 0.682 & -14.21692 & 9.331864 \\
\hline educs & -.1847195 & .0716922 & -2.58 & $\odot .011$ & -.3269548 & -.0424842 \\
\hline lpower & -12.04436 & 5.351661 & -2.25 & 0.027 & -22.6619 & -1.426817 \\
\hline fdi & .0126765 & .3278788 & $\odot .04$ & 0.969 & -.6378257 & .6631787 \\
\hline trade & .0815157 & .0833874 & 0.98 & 0.331 & -.0839225 & .2469539 \\
\hline capital & -.636275 & 1981306 & -3.21 & 0.002 & -1.02936 & -.2431896 \\
\hline dum 92 & .981939 & 1.135388 & 0.86 & 0.389 & -1.270639 & 3.234517 \\
\hline Icid_3 & .1492683 & 28.93688 & 0.01 & 0.996 & -57.26067 & 57.55921 \\
\hline Icid_4 & -9.958968 & 10.29126 & -0.97 & 0.336 & -30.37653 & 10.45859 \\
\hline _cons & -141.5602 & 224.844 & -0.63 & 0.530 & -587.6443 & 304.5239 \\
\hline
\end{tabular}


ASARC Working Paper 2016/01

\section{Table 15: Quantile regression with policy variables (manufacturing)}

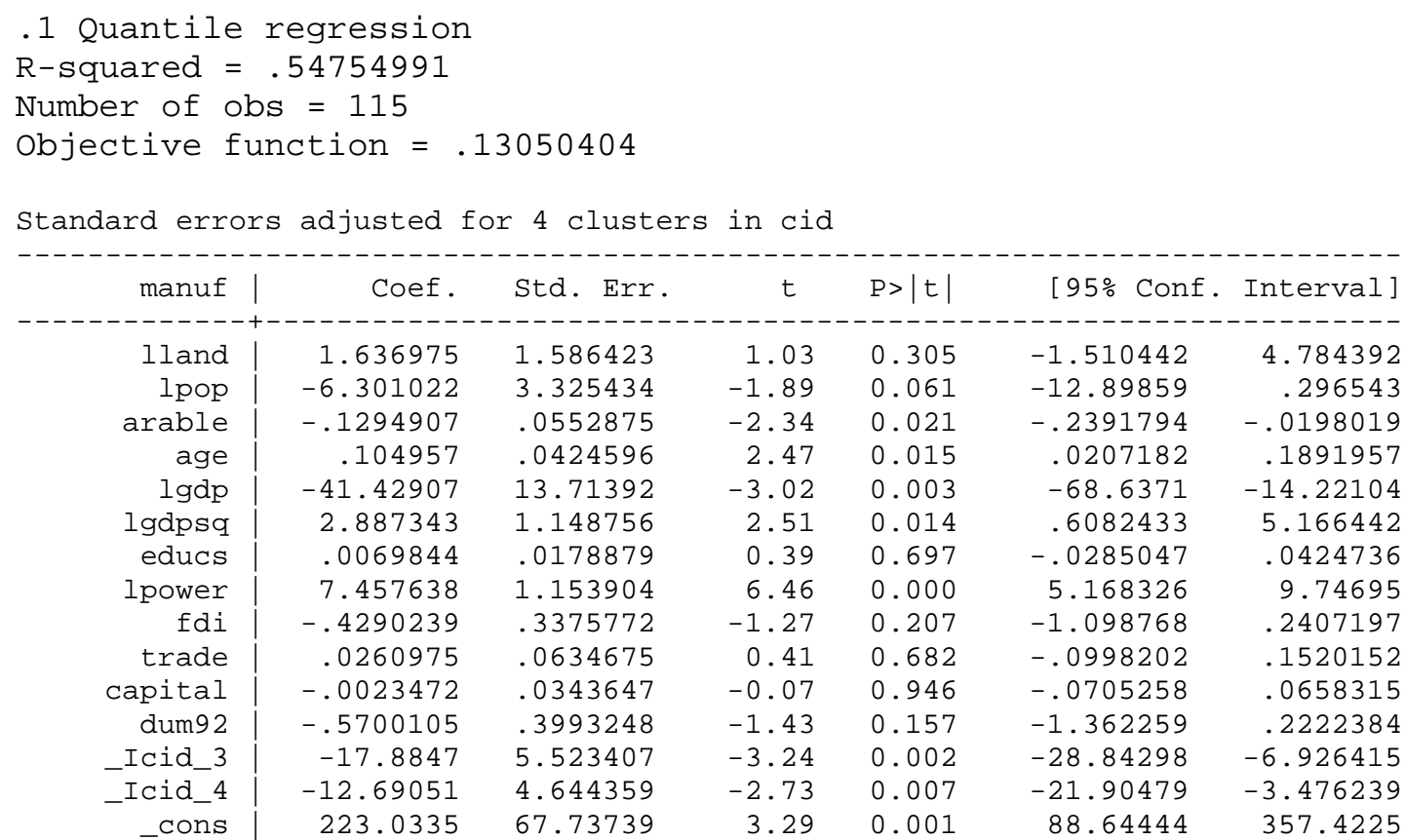

.25 Quantile regression

$\mathrm{R}$-squared $=.5095752$

Number of obs $=115$

Objective function $=.27657024$

Standard errors adjusted for 4 clusters in cid

\begin{tabular}{|c|c|c|c|c|c|c|}
\hline manuf & Coef. & Std. Err. & $\mathrm{t}$ & $P>|t|$ & {$[95 \%$ Conf } & Interval] \\
\hline lland & 1.194164 & 1.494507 & 0.80 & 0.426 & -1.770894 & 4.159223 \\
\hline lpop & -4.565446 & 3.196496 & -1.43 & 0.156 & -10.9072 & 1.776311 \\
\hline arable & -.1798789 & .1019807 & -1.76 & 0.081 & -.3822057 & .0224479 \\
\hline age & .1127833 & .0409382 & 2.75 & 0.007 & .031563 & .1940036 \\
\hline lgdp & -23.47091 & 7.324634 & -3.20 & $\odot .0 \odot 2$ & $-38.0 \odot 278$ & -8.939048 \\
\hline lgdpsq & 1.541291 & .7157741 & 2.15 & 0.034 & .1212153 & 2.961366 \\
\hline educs & .0440608 & .0073349 & 6.01 & $\odot . \odot \odot \odot$ & .0295086 & .058613 \\
\hline lpower & 4.954442 & .8078131 & 6.13 & $\odot .000$ & 3.351764 & 6.55712 \\
\hline$f d i$ & - . 1992173 & .1405 & -1.42 & 0.159 & -.4779652 & .0795307 \\
\hline trade & .0378498 & .073014 & 0.52 & 0.605 & -.1070079 & .1827075 \\
\hline capital & - .0147198 & .072306 & -0.20 & 0.839 & -1581729 & .1287334 \\
\hline dum92 & -.2585254 & .3894292 & -0.66 & 0.508 & -1.031142 & .514091 \\
\hline _Icid_3 & -18.50087 & 8.515248 & -2.17 & 0.032 & -35.39488 & -1.606864 \\
\hline _Icid_4 & -10.97654 & 6.166659 & -1.78 & 0.078 & -23.21101 & 1.257939 \\
\hline _cons & 149.5063 & 48.98227 & 3.05 & 0.003 & 52.32687 & 246.6857 \\
\hline
\end{tabular}


Median regression

R-squared $=.57397295$

Number of obs $=115$

Objective function $=.36824198$

Standard errors adjusted for 4 clusters in cid

\begin{tabular}{|c|c|c|c|c|c|c|}
\hline manuf & Coef. & Std. Err. & $\mathrm{t}$ & $P>|t|$ & {$\left[\begin{array}{ll}95 \% & \text { Conf }\end{array}\right.$} & Interval] \\
\hline lland & .2713517 & 1.371385 & 0.20 & 0.844 & -2.449438 & 2.99214 \\
\hline lpop & -3.880244 & 1.545533 & -2.51 & 0.014 & -6.946538 & -.8139505 \\
\hline arable & -3672767 & .2314123 & -1.59 & 0.116 & -.8263921 & .0918388 \\
\hline age & .1442573 & .0888552 & 1.62 & 0.108 & - . .0320289 & .3205436 \\
\hline $\operatorname{lgdp}$ & -51.14589 & 11.62774 & -4.40 & 0.000 & -74.215 & -28.07678 \\
\hline $\operatorname{lgdpsq}$ & 4.065777 & .8263223 & 4.92 & $\odot .000$ & 2.426377 & 5.705177 \\
\hline educs & - .0249396 & .0696259 & -0.36 & 0.721 & -.1630754 & .1131962 \\
\hline lpower & 3.75237 & 1.071749 & 3.50 & 0.001 & 1.626051 & 5.878689 \\
\hline$f d i$ & -.5226214 & .2571387 & -2.03 & 0.045 & -1.032777 & - .0124654 \\
\hline trade & - .0317069 & .057849 & -0.55 & $\odot .585$ & -.1464776 & .0830638 \\
\hline capital & .0648104 & .1135265 & 0.57 & $\odot .569$ & -.1604231 & .2900438 \\
\hline dum92 & .5332157 & .6041529 & 0.88 & 0.380 & -.6654064 & 1.73183 \\
\hline Icid_3 & -23.31639 & 8.521089 & -2.74 & $\odot .007$ & -40.22199 & -6.41079 \\
\hline Icid_4 & -14.0989 & 3.656393 & -3.86 & $\odot .00 \odot$ & -21.35308 & -6.844724 \\
\hline _cons & 241.0748 & 26.24958 & 9.18 & $\odot .000$ & 188.9964 & 293.153 \\
\hline
\end{tabular}

.75 Quantile regression

$\mathrm{R}$-squared $=.55311283$

Number of obs $=115$

Objective function $=.27910677$

Standard errors adjusted for 4 clusters in cid

\begin{tabular}{|c|c|c|c|c|c|c|}
\hline manuf & Coef. & Std. Err. & $\mathrm{t}$ & $P>|t|$ & [95\% Conf & Interval] \\
\hline lland & -.8273444 & . 9792523 & -0.84 & 0.400 & -2.770153 & 1.115464 \\
\hline lpop & -2.495379 & 1.083275 & -2.30 & 0.023 & -4.644566 & -.346191 \\
\hline arable & - . 4118141 & .0862535 & -4.77 & 0.000 & - . 5829385 & - . 2406897 \\
\hline age & .219991 & . 0832058 & 2.64 & 0.010 & .0549131 & .3850689 \\
\hline $\operatorname{lgdp}$ & -82.07316 & 9.214162 & -8.91 & $\odot . \odot \odot \odot$ & -100.3538 & -63.79253 \\
\hline lgdpsq & 6.301668 & .6798271 & 9.27 & $\odot .000$ & 4.95291 & 7.650425 \\
\hline educs & -.0574856 & .0330774 & -1.74 & 0.085 & -.1231102 & .00813 \\
\hline lpower & 4.668371 & .759208 & 6.15 & $\odot .000$ & 3.162124 & 6.174618 \\
\hline$f d i$ & - . 3702704 & .0482955 & -7.67 & $\odot .000$ & -.4660873 & -.2744535 \\
\hline trade & .0296469 & .01849 & 1.60 & 0.112 & - . . 0070368 & .0663307 \\
\hline capital & .0653075 & .0468353 & 1.39 & 0.166 & - . . 0276124 & .158227 \\
\hline dum92 & 1.845425 & .397905 & 4.64 & $\odot .00 \odot$ & 1.055993 & 2.63485 \\
\hline Icid_3 & -22.0452 & 3.669967 & -6.01 & $\odot .00 \odot$ & -29.32631 & -14.76409 \\
\hline _Icid_4 & -13.99129 & . 8105313 & -17.26 & 0.000 & -15.59936 & -12.38322 \\
\hline _cons & 325.5048 & 20.62413 & 15.78 & $\odot . \odot \odot \odot$ & 284.5871 & 366.422 \\
\hline
\end{tabular}

.9 Quantile regression

R-squared $=.45136139$

Number of obs $=115$

Objective function $=.15404724$

Standard errors adjusted for 4 clusters in cid

\begin{tabular}{l} 
manuf $\mid$ Coef. Std. Err. $t \quad \mathrm{P}>|\mathrm{t}|$ [95\% Conf. Interval] \\
\hline
\end{tabular}


ASARC Working Paper 2016/01

\begin{tabular}{|c|c|c|c|c|c|c|}
\hline lland & - .2707902 & 1.286843 & -0.21 & 0.834 & -2.823851 & 2.28227 \\
\hline lpop & -3.495653 & 1.305523 & -2.68 & $\odot .0 \odot 9$ & -6.085773 & - .9055331 \\
\hline arable & - . .4925425 & .1371029 & -3.59 & $\odot . \odot \odot 1$ & -.7645508 & -.2205343 \\
\hline age & .2741826 & .068689 & 3.99 & $\odot .000$ & .1379056 & .4104596 \\
\hline lgdp & -70.04828 & 12.67708 & -5.53 & $\odot . \odot \odot \odot$ & -95.19925 & -44.89732 \\
\hline lgdpsq & 5.583528 & 9155191 & 6.10 & $\odot .0 \odot \odot$ & 3.767165 & 7.399892 \\
\hline educs & -.1021156 & .0351922 & -2.90 & 0.005 & - . 1719359 & - .0322952 \\
\hline lpower & 4.420255 & 8841061 & 5.00 & $\odot .000$ & 2.666213 & 6.174296 \\
\hline fdi & -.4845785 & .0696782 & -6.95 & $\odot .00 \odot$ & - . 6228181 & - . 3463389 \\
\hline trade & .0215878 & .0110098 & 1.96 & 0.053 & - . . 0002554 & .043431 \\
\hline capital & .0385216 & .0323176 & 1.19 & 0.236 & -.0255956 & .1026388 \\
\hline dum92 & 2.55487 & .7536005 & 3.39 & $\odot .001$ & 1.059748 & 4.049992 \\
\hline _Icid_3 & -26.46998 & 6.80481 & -3.89 & 0.000 & -39.97053 & -12.96943 \\
\hline Icid_4 & -18.69798 & 3.23105 & -5.79 & 0.000 & -25.10829 & -12.28767 \\
\hline _cons & 296.1595 & 29.91387 & 9.90 & $\odot .0 \odot \odot$ & 236.8112 & 355.5078 \\
\hline
\end{tabular}


ASARC Working Paper 2016/01

\section{Table 16: Quantile regression with policy variables (services)}

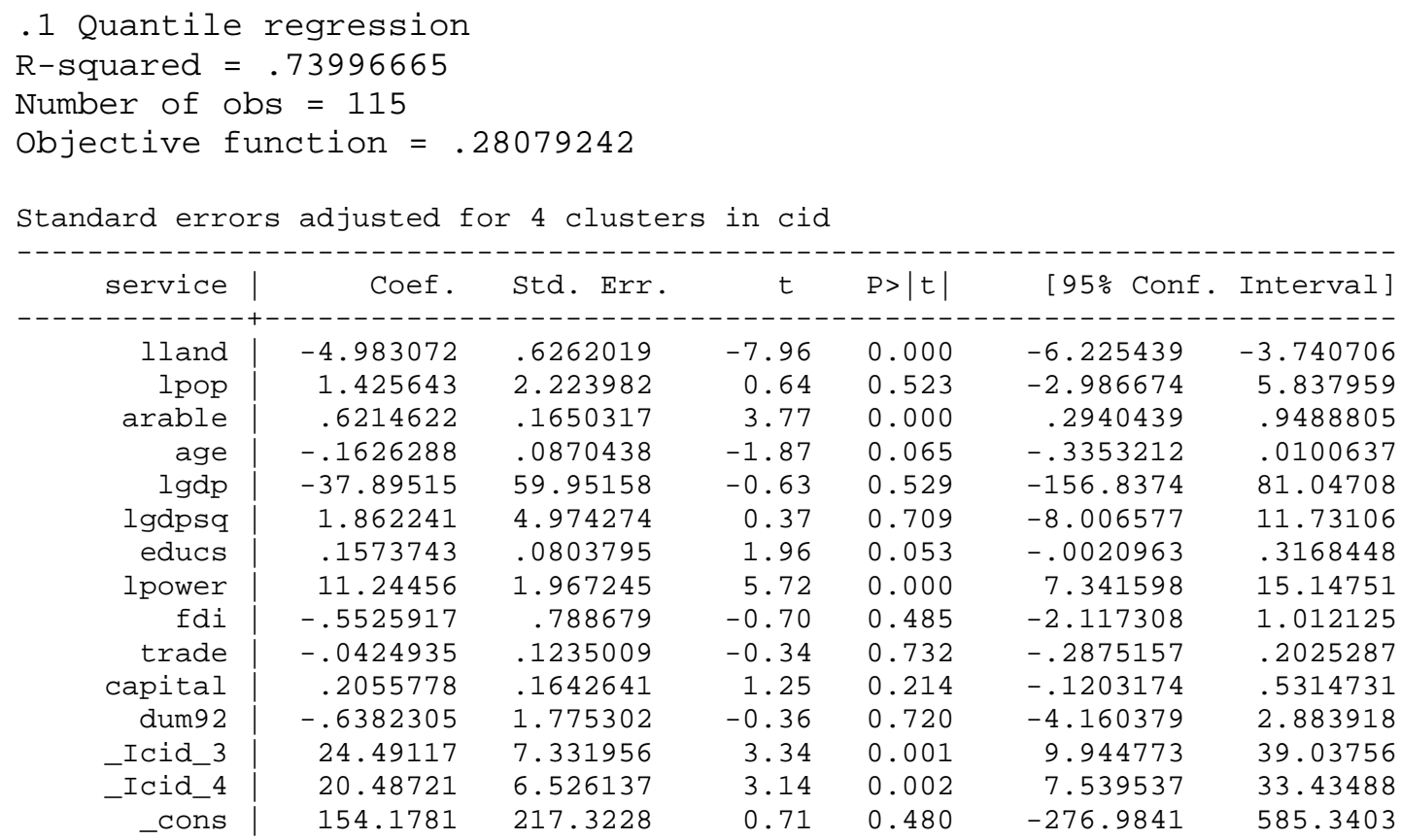

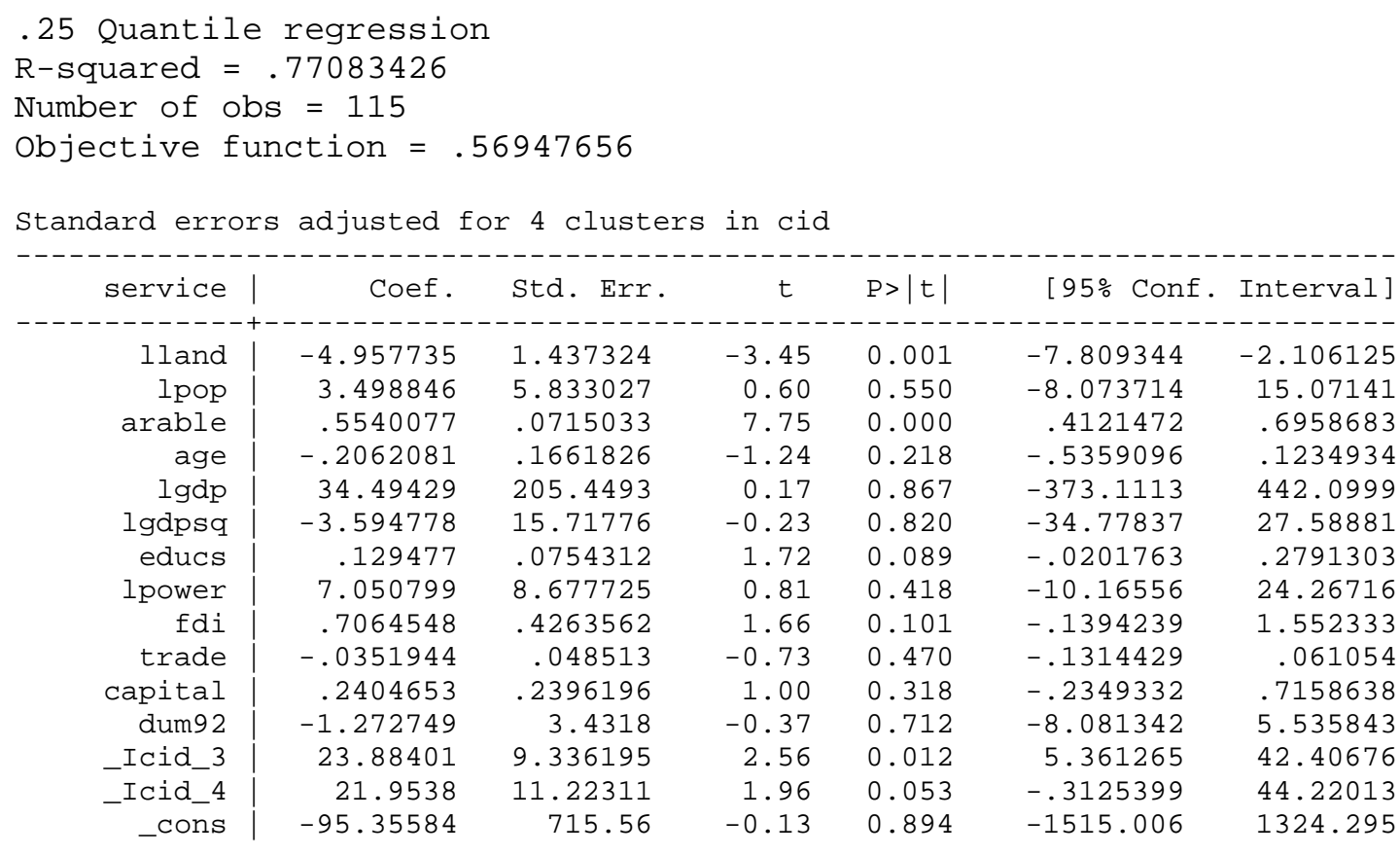

Median regression 
R-squared $=.82384994$

Number of obs $=115$

objective function $=.73076587$

Standard errors adjusted for 4 clusters in cid

\begin{tabular}{|c|c|c|c|c|c|c|}
\hline service | & Coef. & Std. Err. & $\mathrm{t}$ & $P>|t|$ & {$\left[\begin{array}{ll}95 \% & \text { Conf }\end{array}\right.$} & Interval] \\
\hline & & & & & & \\
\hline lland & -3.514151 & 2.398722 & -1.47 & 0.146 & -8.273147 & 1.244845 \\
\hline lpop & 1.332206 & 6.769732 & 0.20 & 0.844 & -12.09875 & 14.76316 \\
\hline arable & .1092798 & .4446383 & 0.25 & 0.806 & -.7728699 & .9914296 \\
\hline age & - . . 4487033 & .2189907 & -0.22 & 0.824 & -.4831746 & .385768 \\
\hline $\operatorname{lgdp}$ & 38.11783 & 73.74652 & 0.52 & 0.606 & -108.1932 & 184.4288 \\
\hline $\operatorname{lgdpsq}$ & -2.730679 & 6.189739 & -0.44 & 0.660 & -15.01095 & 9.549587 \\
\hline educs & .0225371 & .0492199 & 0.46 & 0.648 & - . 0751138 & .120188 \\
\hline lpower & 2.634242 & 4.733476 & 0.56 & 0.579 & -6.756839 & 12.02532 \\
\hline$f d i$ & .2174533 & .5433153 & 0.40 & $\odot .690$ & $-.86 \odot 4687$ & 1.295375 \\
\hline trade & -.1270411 & $.1932 \odot \odot 2$ & -0.66 & $\odot .512$ & -.5103448 & .2562626 \\
\hline capital & .2983675 & .2556847 & 1.17 & $\odot .246$ & -.2089036 & .8056387 \\
\hline dum92 & 1.491898 & 2.129251 & 0.70 & 0.485 & -2.732475 & 5.716271 \\
\hline Icid 3 & 2.477888 & 27.73426 & 0.09 & 0.929 & -52.54609 & 57.50186 \\
\hline Icid_4 & 6.87329 & 18.36561 & 0.37 & 0.709 & -29.56356 & 43.31014 \\
\hline _cons & -82.8377 & 289.5937 & -0.29 & 0.775 & -657.3834 & 491.708 \\
\hline
\end{tabular}

.75 Quantile regression

R-squared $=.79933391$

Number of obs $=115$

Objective function $=.51643201$

Standard errors adjusted for 4 clusters in cid

\begin{tabular}{|c|c|c|c|c|c|c|}
\hline service & Coef. & Std. Err. & $\mathrm{t}$ & $P>|t|$ & [95\% Conf & Interval] \\
\hline 11 and & -1.583726 & 881113 & -189 & 0.975 & -3331829 & 1643767 \\
\hline lpop & -2.188514 & 1.188236 & -1.84 & 0.068 & -4.54594 & .168912 \\
\hline arable & -.187938 & .2375406 & -0.79 & 0.431 & -.6592118 & .2833357 \\
\hline age & .1051716 & . 1469059 & 0.72 & 0.476 & -.1862855 & . 3966287 \\
\hline $\operatorname{lgdp}$ & 59.95266 & 18.79327 & 3.19 & 0.002 & 22.66735 & 97.23797 \\
\hline lgdpsq & -3.792283 & 1.232299 & -3.08 & $\odot .0 \odot 3$ & -6.23713 & -1.347437 \\
\hline educs & .0044928 & .0306611 & 0.15 & $\odot .884$ & - . .0563379 & .0653236 \\
\hline lpower & 6719886 & 1.309349 & $\odot .51$ & 0.609 & -1.925723 & 3. 2697 \\
\hline fdi & .3397026 & .3066944 & 1.11 & $\odot .271$ & -.2687703 & .9481755 \\
\hline trade & -.2289747 & .0394208 & -5.81 & $\odot .0 \odot \odot$ & -.3071843 & -.150765 \\
\hline capital & .2410663 & .1136013 & 2.12 & $\odot .036$ & .0156847 & .466448 \\
\hline dum92 & 3.500662 & 9841392 & 3.56 & $\odot .001$ & 1.548158 & 5.453166 \\
\hline _Icid_3 & -14.12963 & 13.21281 & -1.07 & $\odot .287$ & -40.34346 & 12.08421 \\
\hline Icid_4 & -5.71935 & 7.564772 & -0.76 & 0.451 & -20.72764 & 9.288943 \\
\hline _cons & -111.6273 & 45.01057 & -2.48 & 0.015 & -200.927 & -22.32757 \\
\hline
\end{tabular}




\begin{tabular}{|c|c|c|c|c|c|c|}
\hline $\begin{array}{l}\text { R-squared = } \\
\text { Number of ok } \\
\text { Objective fu }\end{array}$ & $\begin{array}{l}70772922 \\
=115 \\
\text { ction }=.\end{array}$ & 4387024 & & & & \\
\hline tandard erro & adjusted & 4 clust & in cid & & & \\
\hline service & Coef. & Std. Err & $\mathrm{t}$ & $P>|t|$ & {$[95 \%$ Conf } & Interval] \\
\hline & & & & & & \\
\hline lland & -.74513 & 1.569082 & -0.47 & 0.636 & -3.858145 & 2.367885 \\
\hline lpop & -3.56769 & 1.915115 & -1.86 & $\odot .065$ & -7.367223 & .2318438 \\
\hline arable & -.3350155 & .1171706 & -2.86 & 0.005 & -.5674786 & -.1025524 \\
\hline age & .267875 & .104601 & 2.56 & 0.012 & .0603496 & $.47540 \odot 4$ \\
\hline $\operatorname{lgdp}$ & 89.71144 & 19.52305 & 4.60 & $\odot . \odot \odot \odot$ & 50.97827 & 128.4446 \\
\hline lgdpsq & -5.765277 & 1.498781 & -3.85 & $0.00 \odot$ & -8.738815 & -2.791739 \\
\hline educs & .0136984 & .0193979 & 0.71 & 0.482 & -.0247865 & .0521834 \\
\hline lpower & -.5372067 & .4666933 & -1.15 & 0.252 & -1.463113 & .3886994 \\
\hline fdi & .7279203 & .1630767 & 4.46 & 0.000 & .4043808 & 1.05146 \\
\hline trade & -.263411 & .020394 & -12.92 & 0.000 & -.3038721 & -.2229499 \\
\hline capital & .1531702 & .0209518 & 7.31 & $0.00 \odot$ & .1116024 & .1947381 \\
\hline dum92 & 4.870491 & .4123896 & 11.81 & 0.000 & 4.052322 & 5.68866 \\
\hline _Icid_3 & -22.8081 & 3.285548 & -6.94 & $\odot .0 \odot \odot$ & -29.32654 & -16.28967 \\
\hline Icid_4 & -13.01297 & .7097609 & -18.33 & 0.000 & -14.42111 & -11.60482 \\
\hline _cons & -197.7448 & 45.84539 & -4.31 & $\odot .00 \odot$ & -288.7008 & -106.7889 \\
\hline
\end{tabular}


Table 17A: Determinants of Share of Agricultural Sector: Sign and significance of coefficients

\begin{tabular}{|c|c|c|c|c|c|c|c|c|c|c|c|c|c|c|c|}
\hline \multirow{2}{*}{$\begin{array}{l}\text { Variables } \mathbf{} \\
\text { Models } \mathbf{}\end{array}$} & \multicolumn{6}{|c|}{ Fundamentals } & \multicolumn{5}{|c|}{ Policy Variables } & \multicolumn{4}{|c|}{$\begin{array}{l}\text { Time dummy and Country dummies (base } \\
\text { Bangladesh) }\end{array}$} \\
\hline & lland & Ipop & arable & age & $\operatorname{lgdp}$ & Igdps & $\begin{array}{l}\text { educ } \\
\text { s }\end{array}$ & Ipower & open & fdi & capital & $\begin{array}{l}\text { Dum } \\
92\end{array}$ & India & $\begin{array}{l}\text { Sri } \\
\text { Lanka }\end{array}$ & Pakistan \\
\hline $\begin{array}{l}\text { Pooled OLS (Table3) } \\
\text { (fundamentals only) }\end{array}$ &,$+ S$ &,$- \mathrm{S}$ &,$+ s$ &,$+ S$ &,$+ \mathrm{i}$ &,$- \mathrm{i}$ & & & & & &,$+ \mathrm{i}$ &,$+ \mathrm{i}$ &,$+ i$ & \\
\hline $\begin{array}{l}\text { Pooled OLS (Table5) } \\
\text { (fundamentals \& } \\
\text { policy variables) }\end{array}$ &,$+ s$ &,$- \mathrm{i}$ &,$+ \mathrm{i}$ &,$- \mathrm{i}$ &,$- \mathrm{i}$ &,$+ \mathrm{i}$ &,$+ \mathrm{i}$ &,$- \mathrm{S}$ &,$+ \mathrm{s}$ &,$+ \mathrm{i}$ &,$- \mathrm{S}$ &,$- \mathrm{i}$ &,$- \mathrm{i}$ &,$- \mathrm{i}$ & \\
\hline $\begin{array}{l}\text { SUR with constraints } \\
\text { (Table 6) }\end{array}$ &,$+ \mathrm{i}$ &,$+ \mathrm{i}$ &,$- \mathrm{i}$ &,$+ \mathrm{i}$ &,$- \mathrm{i}$ &,$+ \mathrm{i}$ &,$- \mathrm{i}$ &,$- \mathrm{S}$ &,$+ \mathrm{s}$ & &,$- \mathrm{S}$ &,$+ \mathrm{s}$ &,$+ \mathrm{i}$ &,$+ i$ & \\
\hline $\begin{array}{l}\text { Fixed effects model } \\
\text { with country } \\
\text { fundamentals (Table } \\
7 \text { ) }\end{array}$ & &,$- S$ &,$+ s$ &,$+ s$ &,$+ \mathrm{i}$ &,$- \mathrm{i}$ & & & & & &,$+ \mathrm{i}$ & & & \\
\hline $\begin{array}{l}\text { Random Effects } \\
\text { model with country } \\
\text { fundamentals (Table } \\
\text { 8) }\end{array}$ &,$+ \mathrm{i}$ &,$- \mathrm{i}$ &,$+ \mathrm{i}$ &,$+ S$ &,$- \mathrm{S}$ &,$+ \mathrm{s}$ & & & & & &,$- \mathrm{S}$ & & & \\
\hline $\begin{array}{l}\text { Fixed Effects model } \\
\text { with policy variables } \\
\text { (Table 9) }\end{array}$ & &,$- \mathrm{i}$ &,$+ \mathrm{i}$ &,$- i$ &,$- \mathrm{i}$ &,$+ \mathrm{i}$ &,$+ \mathrm{i}$ &,$- \mathrm{S}$ &,$+ s$ &,$+ \mathrm{i}$ &,$- \mathrm{s}$ &,$- \mathrm{i}$ & & & \\
\hline $\begin{array}{l}\text { Random Effects } \\
\text { model with policy } \\
\text { variables (Table 10) }\end{array}$ &,$+ s$ &,$- \mathrm{i}$ &,$+ \mathrm{i}$ &,$- i$ &,$- \mathrm{i}$ &,$+ \mathrm{i}$ &,$+ \mathrm{i}$ &,$- \mathrm{S}$ &,$+ s$ &,$+ i$ &,$- \mathrm{S}$ &,$- \mathrm{i}$ &,$- \mathrm{i}$ &,$+ \mathrm{i}$ & \\
\hline $\begin{array}{l}\text { Summary of Quantile } \\
\text { regression results } \\
\text { (Table 11) only } \\
\text { significant results } \\
\text { mentioned. }\end{array}$ & & & $\begin{array}{l}+, s \\
\text { (for } \\
0.5 \\
\text { and } \\
0.75 \text { ) }\end{array}$ & & $\begin{array}{l}-s, \\
\text { (for } \\
0.9 \text { ) }\end{array}$ & $\begin{array}{l}+, s \text { (for } \\
0.9)\end{array}$ & & & & & & & & & \\
\hline $\begin{array}{l}\text { Summary of quantile } \\
\text { regressions (Table 14) }\end{array}$ & $\begin{array}{l}\text {-,s for } 0.1, \\
+, \mathrm{s} \text { for } 0.5 \\
\text { and } 0.9\end{array}$ & $\begin{array}{l}+, s \text { for } \\
0.1 \\
0.25\end{array}$ & $\begin{array}{l}+, s \text { for } \\
0.1 \\
0.25 \\
0.75\end{array}$ & $\begin{array}{l}-, \mathrm{s} \text { for } \\
0.1 \\
0.25\end{array}$ & $\begin{array}{l}-, S \\
\text { for } \\
0.1 \\
0.25\end{array}$ & $\begin{array}{l}+, s \text { for } \\
0.1 \\
0.25\end{array}$ & $\begin{array}{l}+, s \\
\text { for } \\
0.25, \\
-, s \\
\text { for } \\
0.9 \\
\end{array}$ & $\begin{array}{l}-s \text { for } \\
0.1 \text {, } \\
0.25, \\
0.75 \\
\text { and } \\
0.9 \\
\end{array}$ & $\begin{array}{l}+, s \\
\text { for } \\
0.1 \\
0.25\end{array}$ & $\begin{array}{l}+, s \\
\text { for } \\
0.25\end{array}$ & $\begin{array}{l}-, s \text { for } \\
0.1 \\
0.25 \\
0.75 \\
0.9\end{array}$ & $\begin{array}{l}-, s \\
\text { for } \\
0.1 \\
0.25\end{array}$ & & $\begin{array}{l}+, s \text { for } \\
0.1 \\
0.25\end{array}$ & $\begin{array}{l}+, s \text { for } \\
0.1,0.25\end{array}$ \\
\hline
\end{tabular}

N.B. $\mathrm{i}=$ insignificant, $\mathrm{s}=$ significant, usually at 5 per cent or lower. Quantile regression results show significance for relevant quantiles only. 
Table 17B: Determinants of Share of Manufacturing Sector: Sign and significance of coefficients

\begin{tabular}{|c|c|c|c|c|c|c|c|c|c|c|c|c|c|c|c|}
\hline \multirow{2}{*}{$\begin{array}{l}\text { Variables } \\
\text { Models } \mathbf{\nabla}\end{array}$} & \multicolumn{6}{|c|}{ Fundamentals } & \multicolumn{5}{|c|}{ Policy Variables } & \multicolumn{4}{|c|}{$\begin{array}{l}\text { Time dummy and Country dummies (base } \\
\text { Bangladesh) }\end{array}$} \\
\hline & lland & Ipop & arable & age & Igdp & lgdps & $\begin{array}{l}\text { educ } \\
\text { s }\end{array}$ & Ipower & open & fdi & capital & $\begin{array}{l}\text { Dum } \\
92\end{array}$ & India & $\begin{array}{l}\text { Sri } \\
\text { Lanka }\end{array}$ & Pakistan \\
\hline $\begin{array}{l}\text { Pooled OLS (Table3) } \\
\text { (fundamentals only) }\end{array}$ &,$- \mathrm{i}$ &,$+ \mathrm{s}$ &,$- \mathrm{S}$ &,$- \mathrm{S}$ &,$- \mathrm{i}$ &,$+ i$ & & & & & &,$- i$ &,$- \mathrm{i}$ &,$- i$ & \\
\hline $\begin{array}{l}\text { Pooled OLS (Table5) } \\
\text { (fundamentals \& } \\
\text { policy variables) }\end{array}$ &,$- \mathrm{S}$ &,$- i$ &,$- \mathrm{S}$ &,$+ S$ &,$- S$ &,$+ s$ &,$- \mathrm{i}$ &,$+ \mathrm{s}$ &,$- \mathrm{i}$ &,$- S$ &,$+ \mathrm{s}$ &,$+ \mathrm{i}$ &,$+ s$ &,$- \mathrm{S}$ & \\
\hline $\begin{array}{l}\text { SUR with constraints } \\
\text { (Table 6) }\end{array}$ &,$- S$ &,$- S$ & &,$+ \mathrm{s}$ &,$- S$ &,$+ \mathrm{s}$ &,$- \mathrm{i}$ &,$+ \mathrm{s}$ &,$+ \mathrm{i}$ &,$- \mathrm{i}$ &,$+ \mathrm{i}$ &,$+ \mathrm{s}$ &,$+ \mathrm{s}$ &,$- S$ & \\
\hline $\begin{array}{l}\text { Fixed effects model } \\
\text { with country } \\
\text { fundamentals (Table } \\
7 \text { ) }\end{array}$ & &,$+ s$ & $-\mathrm{s}$ &,$- \mathrm{S}$ &,$- \mathrm{i}$ &,$+ i$ & & & & & &,$- \mathrm{i}$ & & & \\
\hline $\begin{array}{l}\text { Random Effects } \\
\text { model with country } \\
\text { fundamentals (Table } \\
\text { 8) }\end{array}$ &,$+ \mathrm{i}$ &,$+ \mathrm{i}$ &,$- \mathrm{S}$ &,$- \mathrm{i}$ &,$+ \mathrm{i}$ &,$- \mathrm{i}$ & & & & & &,$- \mathrm{i}$ & & & \\
\hline $\begin{array}{l}\text { Fixed Effects model } \\
\text { with policy variables } \\
\text { (Table 9) }\end{array}$ & &,$- \mathrm{i}$ &,$- \mathrm{S}$ &,$+ \mathrm{s}$ &,$- \mathrm{S}$ &,$+ s$ &,$- i$ &,$+ \mathrm{s}$ &,$- i$ &,$- \mathrm{S}$ &,$+ i$ &,$+ \mathrm{i}$ & & & \\
\hline $\begin{array}{l}\text { Random Effects } \\
\text { model with policy } \\
\text { variables (Table 10) }\end{array}$ &,$- \mathrm{S}$ &,$- \mathrm{i}$ &,$- S$ &,$+ \mathrm{s}$ &,$- \mathrm{S}$ &,$+ \mathrm{s}$ &,$- \mathrm{i}$ &,$+ s$ &,$- \mathrm{i}$ &,$- S$ &,$+ \mathrm{s}$ &,$+ \mathrm{i}$ &,$+ s$ &,$- S$ & \\
\hline $\begin{array}{l}\text { Summary of Quantile } \\
\text { regression results } \\
\text { (Table 12) }\end{array}$ & & & $\begin{array}{l}-\mathrm{s}, \text { for } \\
0.1, \\
0.25, \\
\text { and } \\
0.5) \\
\end{array}$ & & & & & & & & & $\begin{array}{l}-, \mathrm{s} \\
\text { for } \\
0.5 \\
\text { and } \\
0.9\end{array}$ & & & \\
\hline $\begin{array}{l}\text { Summary of Quantile } \\
\text { regression results } \\
\text { (Table 15) }\end{array}$ & & $\begin{array}{l}-,-s \text { for } \\
0.1,0.7 \\
5,0.9\end{array}$ & $\begin{array}{l}-, \mathrm{s} \text { for } \\
0.1 \\
0.25,0 . \\
75,0.9\end{array}$ & $\begin{array}{l}, s \text { for } \\
0.1 \\
0.25 \\
0.75 \\
0.9\end{array}$ & $\begin{array}{l}-,-s \\
\text { for } \\
0.1, \\
0.25, \\
0.5, \\
0.75, \\
0.9\end{array}$ & $\begin{array}{l}, \mathrm{s} \text { for } \\
0.1, \\
0.25, \\
0.5, \\
0.75, \\
0.9\end{array}$ & $\begin{array}{l}, s \\
\text { for } \\
0.25 ; \\
-s \text { for } \\
0.75 \\
\text { and } \\
0.9\end{array}$ & $\begin{array}{l}+, \text { for } \\
0.1 \\
0.25, \\
0.5 \text {, } \\
0.75 \text {, } \\
0.9\end{array}$ & $\begin{array}{l}+, s \\
\text { for } \\
0.9\end{array}$ & $\begin{array}{l}-, \mathrm{s} \\
\text { for } \\
0.5, \\
0.75 \\
\text { and } \\
0.9\end{array}$ & & $\begin{array}{l}+s \\
\text { for } \\
0.75 \\
\text { and } \\
0.9\end{array}$ & & $\begin{array}{l}-, \mathrm{s} \text { for } \\
0.1 \text {, } \\
0.25 \text {, } \\
0.5 \\
0.75 \\
0.9\end{array}$ & $\begin{array}{l}-, \text { for } \\
0.1 \\
0.25 \\
0.5 \\
0.75 \\
0.9\end{array}$ \\
\hline
\end{tabular}

N.B. $\mathrm{i}=$ insignificant, $\mathrm{s}=$ significant, usually at 5 per cent or lower. Quantile regression results show significance for relevant quantiles only. 
Table 17C: Determinants of Share of Services Sector: Sign and significance of coefficients

\begin{tabular}{|c|c|c|c|c|c|c|c|c|c|c|c|c|c|c|c|}
\hline \multirow{2}{*}{$\begin{array}{l}\text { Variables } \mathbf{} \\
\text { Models } \mathbf{\nabla} \\
\end{array}$} & \multicolumn{6}{|c|}{ Fundamentals } & \multicolumn{5}{|c|}{ Policy Variables } & \multicolumn{4}{|c|}{$\begin{array}{l}\text { Time dummy and Country dummies (base } \\
\text { Bangladesh) }\end{array}$} \\
\hline & Illand & Ipop & arable & age & Igdp & Igdps & $\begin{array}{l}\text { educ } \\
s\end{array}$ & Ipower & open & fdi & capital & $\begin{array}{l}\text { Dum } \\
92\end{array}$ & India & $\begin{array}{l}\text { Sri } \\
\text { Lanka }\end{array}$ & Pakistan \\
\hline $\begin{array}{l}\text { Pooled OLS (Table3) } \\
\text { (fundamentals only) }\end{array}$ &,$- S$ &,$+ s$ &,$- S$ & $-\mathrm{i}$ &,$- \mathrm{S}$ &,$+ \mathrm{s}$ & & & & & &,$+ S$ &,$- \mathrm{i}$ &,$- \mathrm{i}$ & \\
\hline $\begin{array}{l}\text { Pooled OLS (Table5) } \\
\text { (fundamentals \& } \\
\text { policy variables) }\end{array}$ &,$- i$ &,$+ i$ &,$- \mathrm{i}$ &,$- \mathrm{i}$ &,$+ i$ &,$- \mathrm{i}$ &,$+ i$ &,$+ i$ &,$- S$ &,$+ i$ &,$+ s$ &,$+ \mathrm{s}$ &,$- \mathrm{i}$ &,$+ i$ & \\
\hline $\begin{array}{l}\text { SUR with constraints } \\
\text { (Table 6) }\end{array}$ &,$- \mathrm{i}$ &,$+ i$ &,$+ i$ & $-\mathrm{i}$ &,$+ \mathrm{S}$ &,$- \mathrm{S}$ &,$- \mathrm{i}$ &,$+ S$ &,$- \mathrm{S}$ &,$+ s$ &,$+ \mathrm{s}$ &,$+ \mathrm{s}$ &,$- \mathrm{i}$ &,$+ i$ & \\
\hline $\begin{array}{l}\text { Fixed effects model } \\
\text { with country } \\
\text { fundamentals (Table } \\
\text { 7) }\end{array}$ & &,$+ s$ &,$- \mathrm{S}$ & $\begin{array}{l}-\mathrm{i} \\
\end{array}$ &,$- S$ &,$+ s$ & & & & & &,$+ \mathrm{s}$ & & & \\
\hline $\begin{array}{l}\text { Random Effects } \\
\text { model with country } \\
\text { fundamentals (Table } \\
\text { 8) }\end{array}$ & 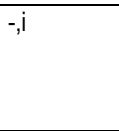 &,$+ i$ &,$- \mathrm{i}$ &,$+ i$ &,$+ S$ & $-\mathrm{S}$ & & & & & &,$+ \mathrm{s}$ & & & \\
\hline $\begin{array}{l}\text { Fixed Effects model } \\
\text { with policy variables } \\
\text { (Table 9) }\end{array}$ & &,$+ i$ &,$- i$ &,$- \mathrm{i}$ &,$+ i$ &,$- \mathrm{i}$ &,$+ i$ &,$+ i$ &,$- \mathrm{S}$ &,$+ i$ &,$+ s$ &,$+ s$ & & & \\
\hline $\begin{array}{l}\text { Random Effects } \\
\text { model with policy } \\
\text { variables (Table 10) }\end{array}$ & $\begin{array}{l}-\mathrm{i} \\
\end{array}$ &,$+ i$ & $-\mathrm{i}$ & $\begin{array}{l}-\mathrm{i} \\
\end{array}$ &,$+ i$ &,$- \mathrm{i}$ &,$+ i$ &,$+ i$ &,$- \mathrm{S}$ &,$+ i$ &,$+ s$ &,$+ \mathrm{s}$ &,$- \mathrm{i}$ & $-\mathrm{i}$ & \\
\hline $\begin{array}{l}\text { Summary of Quantile } \\
\text { regression results } \\
\text { (Table 13) }\end{array}$ & $\begin{array}{l}-, \mathrm{S} \text { at } 0.1 \\
0.5,0.75 \\
\text { and } 0.9 \text {. }\end{array}$ & $\begin{array}{l}+, s \text { for } \\
0.5 \\
0.9\end{array}$ & $\begin{array}{l}-\mathrm{S} \text { at } \\
0.1 \\
0.75 \\
\text { and } \\
0.9\end{array}$ & & & & & & & & & $\begin{array}{l}+, \mathrm{s} \\
0.1 \\
\text { and } \\
0.9\end{array}$ & & & \\
\hline $\begin{array}{l}\text { Summary of Quantile } \\
\text { regression results } \\
\text { (Table 16) }\end{array}$ & $\begin{array}{l}-, s \text { for } 0.1, \\
0.25,0.75\end{array}$ & $\begin{array}{l}-, \mathrm{s} \text { for } \\
0.9\end{array}$ & $\begin{array}{l}+, \text { for } \\
0.1, \\
0.25, \\
\text { and-,s } \\
\text { for } 0.9\end{array}$ & $\begin{array}{l}-, \mathrm{s} \text { for } \\
0.1,+, \mathrm{S} \\
\text { for } 0.9\end{array}$ & $\begin{array}{l}+, S \\
\text { for } \\
0.75 \\
\text { and } \\
0.9\end{array}$ & $\begin{array}{l}-s \text { for } \\
0.75 \\
0.9\end{array}$ & $\begin{array}{l}+, S \\
\text { for } \\
0.1 \\
0.25\end{array}$ & $\begin{array}{l}+, s \text { for } \\
0.1\end{array}$ & $\begin{array}{l}-, \mathrm{S} \\
\text { for } \\
0.75 \\
\text { and } \\
0.9 \\
\end{array}$ & $\begin{array}{l}+, S \\
\text { for } \\
0.9\end{array}$ & $\begin{array}{l}+, \text { for } \\
0.75 \\
0.9\end{array}$ & $\begin{array}{l}+, s \\
\text { for } \\
0.75 \\
0.9\end{array}$ & & $\begin{array}{l}+, s \text { for } \\
0.1 \\
0.25 ;-, s \\
\text { for } 0.9\end{array}$ & $\begin{array}{l}+, s \text { for } \\
0.1,0.25 \\
\text { and }-, s \\
\text { for } 0.9\end{array}$ \\
\hline
\end{tabular}

N.B. $\mathrm{i}=$ insignificant, $\mathrm{s}=$ significant, usually at 5 per cent or lower. Quantile regression results show significance for relevant quantiles only. 